\title{
COMPARAÇÃO DE DUAS METODOLOGIAS DE SELEÇÃO NO DESENVOLVIMENTO DE POPULAÇÕES DE MILHO (Zea mays L.) TOLERANTES A SOLOS ÁCIDOS.
}

\author{
Carlos daniel giaveno \\ Engenheiro Agrônomo
}

Orientador: Prof. Dr. JOSÉ BRANCO DE MIRANDA FILHO

Tese apresentada à Escola Superior de Agricultura

" Luiz de Queiroz ", Universidade de São Paulo, Para obtenção do título de Doutor em Agronomia, Área de Concentração: Genética e Melhoramento de Plantas.

PIRACICABA

Estado de São Paulo - Brasil

Junho - 2000 


\section{ERRATA}

Carlos Daniel Giaveno. Comparação de duas metodologias de seleção no desenvolvimento de populações de milho (Zea mays L.) tolerantes a solos ácidos.

\begin{tabular}{ccccc}
\hline p. & Item & Linha & Onde se lê & Leia - se \\
23 & 3.3 .2 .2 & Tabela 23 & $\mathrm{E}-\mathrm{F}$ & $\mathrm{CV}$ \\
24 & 3.3 .2 .2 & décimo primeira & $\mathrm{E}-\mathrm{F}$ & $\mathrm{CV}$ \\
28 & 3.4 .2 .1 & As fórmulas utilizadas para cálculo das variâncias ao nível de médias de \\
& & famílias não devem ser consideradas. & \\
30 & 3.5 .1 .2 .1 & décimo quinta & gel de amido e agarose & gel de amido e penerose \\
46 & 4.3 .1 .1 & Tabela 8 & Ciclo E - F & CV \\
47 & 4.3 .1 .1 & sétima & Figura $8 \mathrm{~B}$ & Tabela 8 \\
66 & 4.3 .1 .5 & Tabela 17 & 91,2 & 9,12 \\
70 & 4.3 .1 .6 & primeira & $34,7 \%$ & $53,2 \%$ \\
70 & 4.3 .1 .6 & décimo primeira & $32,6 \%$ & $15,3 \%$ \\
76 & 4.3 .3 .2 .1 & Tabela 24 & ABBBCCDE & BCADBCBE \\
80 & 4.4 .1 & Figura 12 & Número de plântulas & Número de progênies \\
\hline
\end{tabular}




\title{
Dados Internacionais de Catalogação na Publicação (CIP) DIVISÃO DE BIBLIOTECA E DOCUMENTAÇÃO - Campus "Luiz de Queiroz"/USP
}

\author{
Giaveno, Carlos Daniel \\ Comparação de duas metodologias de seleção no desenvolvimento de populaçōes de \\ milho (Zea mays L.) tolerantes a solos ácidos / Carlos Daniel Giaveno. - - Piracicaba, 2000. \\ 103 p. : il. \\ Tese (doutorado) - Escola Superior de Agricultura Luiz de Queiroz, 2000. \\ Bibliografia. \\ 1. Marcador genético 2. Milho 3. População de planta 4. Solo ácido 5. Tolerância ao \\ alumínio I. Título
}

CDD 633.15

\section{Permitida a cópla total ou parcial deste documento, desde que citada a fonte -0 autor?}

Data do dopósito junto à CPG/ESALQ

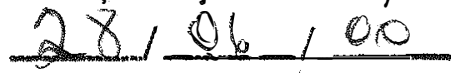


A minha esposa Nirlei e a meu filho Bruno que com seu amor motivam minha vida.

\section{DEDICO}

Aos meus pais Amanda e Mario, pelo amor e o apoio recebido ao longo da minha vida. 


\section{AGRADECIMENTOS}

O autor deseja expressar os seus agradecimentos a todas aquelas pessoas envolvidas direta ou indiretamente na realização deste trabalho e em especial:

- Ao Prof. Dr. José Branco de Miranda Filho pela orientação e pelos conhecimentos com ele adquiridos. Ao amigo Zé Branco e a sua família, que tanto ajudaram na minha adaptação.

- A minha esposa Nirlei A. Silva, pela compreensão e carinho sempre constantes e pela ajuda na revisão ortográfica e gramatical.

- À Fundação de Amparo à Pesquisa do Estado de São Paulo (FAPESP) pela concessão de Bolsa de Estudos.

- Ao Dr. Pedro Roberto Furlani do Instituto Agronómico de Campinas (IAC) pelos ensinamentos e por facilitar um espaço na Seção de milho onde foi possivel a realização de parte deste trabalho.

- Ao Prof. Dr. Aikihiko Ando, do Laboratório de Ecologia Evolutiva e Genética Aplicada da ESALQ-USP, por permitir a utilização dessas instalações para a realização de parte do trabalho.

-Ao Prof. Dr. Ricardo Ferraz de Oliveira, do Laboratório de Fisiologia de Plantas em Condições de Estresse da ESALQ-USP, por facilitar a utilização de instalações e equipamento. 
- Ao Dr. Osmar Vilela da Estação Experimental de Pindamonhangaba do IAC, por permitir a realização do ensaio de campo.

- Ao Dr. Sidney Neto Parentoni da EMBRAPA Milho e Sorgo da por facilitar a realização de experimentos e pelas sugestões recebidas.

- Ao Dr. Luciano L. Nass pelas valiosas sugestões e pela ajuda na revisão deste documento.

- Aos amigos Ronaldo Rabelo, Marcos Cella e Carlos Basso pelo auxílio indispensável na condução dos experimentos de campo.

- Aos amigos Inez F. Faraldo e Rainerio M. da Silva cuja ajuda foi fundamental para o desenvolvimento do trabalho com marcadores bioquímicos e pela leitura e correção do texto.

- À bibliotecária Eliana Maria Garcia pela correção das referências bibliográficas.

- Aos professores do Departamento de Genética da ESALQ/USP pelos ensinamentos que contribuíram para minha formação. 


\section{SUMÁRIO}

Página

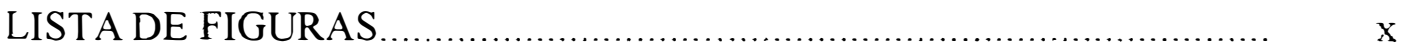

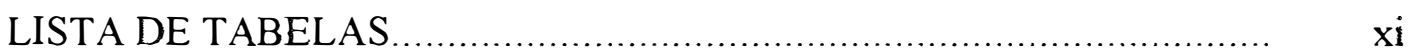

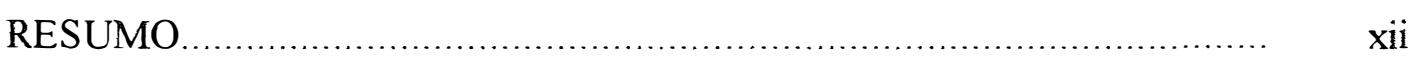

SUMMARY

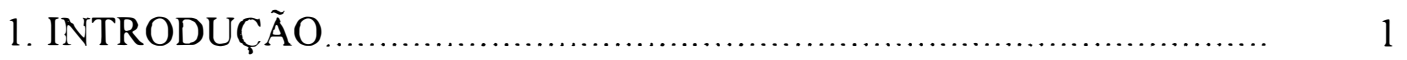

2. REVISÃO DE LITERATURA ............................................. 4

2.1 Solos ácidos e produção vegetal ...................................... 4

2.2 Efeito do alumínio nas plantas ....................................... 5

2.3 Mecanismos de tolerância ao aluminio presentes nas plantas............... 6

2.4 Bases genéticas da tolerância ao alumínio em plantas superiores.......... 8

2.5 Melhoramento genético visando tolerância ao alumínio........................ 9

2.6 Utilização de seleção assistida por marcadores.............................. 11

2.7 Utilização de germoplasma exótico em programas de melhoramento..... $\quad 12$

3 MATERIAL E MÉTODOS .................................................. 14

3.1 PRIMEIRA ETAPA: Estudo de variabilidade e selação....................... 15

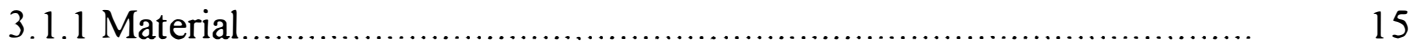

3.1.2 Metodologia 15

3.1.2.1 Método 1: Estudo de variabilidade e seleção em solo álico............ 16

3.1.2.1 Método 2: Estudo de variabilidade e seleção em solução nutritiva.. 17

3.1.3 Delineamento experimental utilizado..................................... 18

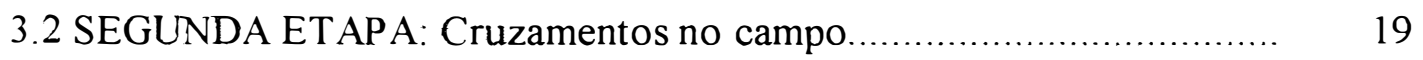

3.2.1 Obtenção das novas populações............................................... 19

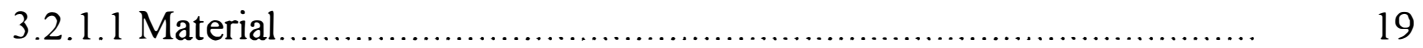

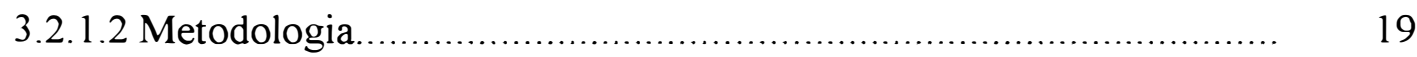


3.2.2 Obtenção das progênies de meios irmãos .......................................... 19

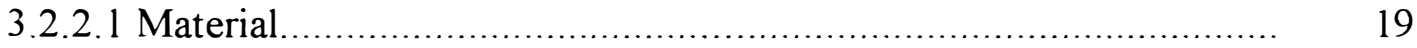

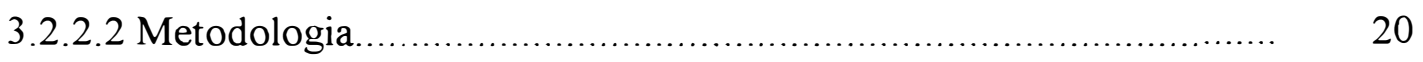

3.3 TERCEIRA ETAPA: Comparação das populações obtidas pelas duas

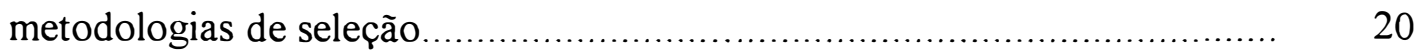

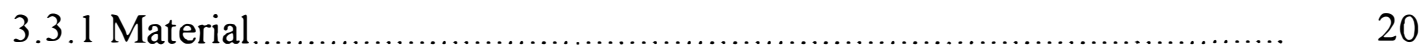

3.3.2 Experimentos de campo ...................................................... 21

3.3.2.1 Ambientes de avaliação........................................................... 21

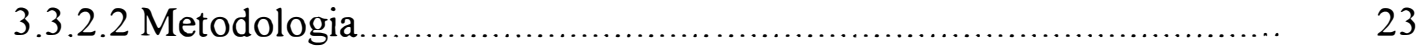

3.3.3 Experimentos em casa de vegetação............................................ 25

3.3.3.1 Experimentos em vasos com solo álico........................................ 25

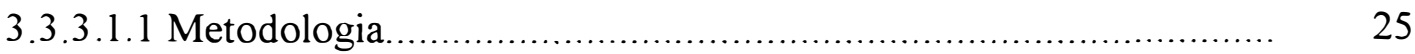

3.3.3.2 Experimentos em solução nutritiva ............................................. 26

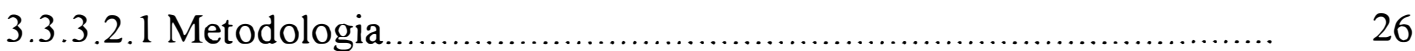

3.4 QUARTA ETAPA: Teste de progênies e estimação de parâmetros

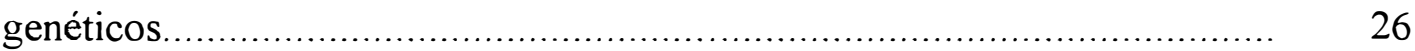

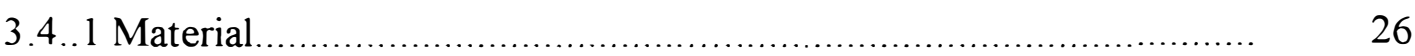

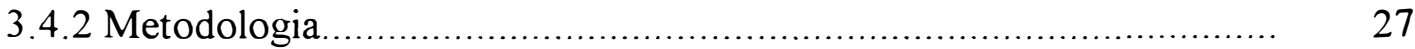

3.4.2.1 Estimação dos componentes da variância ...................................... 27

3.4.2.2 Estimação do coeficiente de herdabilidade..................................... 29

3.4.2.3 Estimação do progresso esperado por seleção................................ 29

3.5 QUINTA ETAPA: Avaliação da utilização de marcadores bioquímicos 30

3.5.1 Isoenzimas: Experimentos preliminares........................................ 30

3.5.1.1 Material ......................................................................... 30

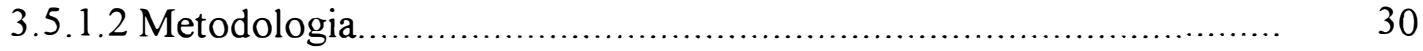

3.5.1.2.1 Tipos de geis testados ....................................................

3.5.1.2.2 Colheita das amostras de tecido......................................... 32 
3.5.1.2.3 Indução da atividade enzimática pela presença de alumínio.......... 32

3.5.1.2.4 Intensidade e duração das corridas eletroforéticas.................... 32

3.5.1.2.5 Sistemas isoenzimáticos testados................................... 32

3.5.2 Coloração com hematoxilina: Experimentos preliminares................ 33

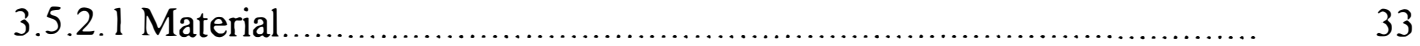

3.5.2.2 Experimento 1: Determinação do tempo de exposição ao alumínio.. 34

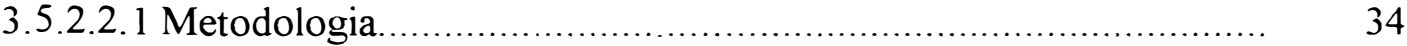

3.5.2.3 Experimento 2: Otimização dos tempos de lavagem e coloração.... 35

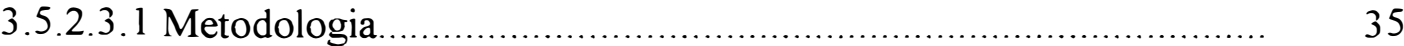

3.5.2.4 Experimento final: Comprovação da eficiência da técnica.............. 35

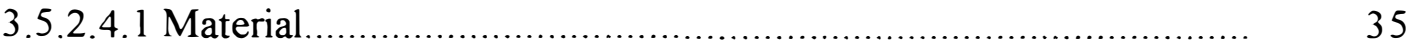

3.5.2.4.2 Metodologia ................................................................ 35

3.5.2.4.2.1 Crescimento das plântulas .......................................... 35

3.5.2.4.2.2 Coloração com hematoxilina......................................... 36

4 RESULTADOS E DISCUSSÃO............................................. 37

4.1 PRIMEIRA ET APA: Estudo de variabilidade e selação..................... 37

4.1.1 Método 1: Estudo de variabilidade e seleção em solo álico............... 37

4.1.2 Método 2: Estudo de variabilidade e seleção em solução nutritiva..... 39

4.2 SEGUNDA ETAPA: Cruzamentos no campo.............................. 42

4.3 TERCEIRA ETAPA: Comparação das populações obtidas pelas duas $\quad 42$

metodologias de seleção

4.3.1 Experimentos de campo: Análises em cada local....................... 42

4.3.1.1 Experimento em safrina - Depto. Genética, Piracicaba SP............ 42

4.3.1.2 Experimento em em safrina- Fazenda Anhembi, Anhumas SP........ 47

4.3.1.3 Experimento em safrina - Pindamonhangaba SP, Fazenda IAC...... 56

4.3.1.4 Experimento em época normal - Depto. Genética, Piracicaba SP.... 58

4.3.1.5 Experimentos em época normal - Fazenda Anhembi, Anhumas SP.. 62 
4.3.1.6 Experimento em época normal- EMBRAPA, Sete Lagoas MG...... 69

4.3.2 Experimentos de campo: Análise em vários ambientes................... 71

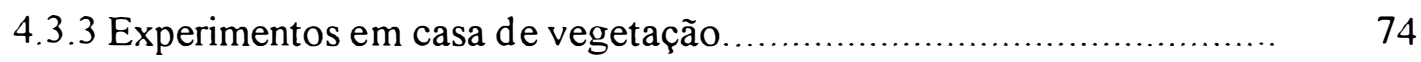

4.3.3.1 Experimentos em vasos com solo álico.................................. 74

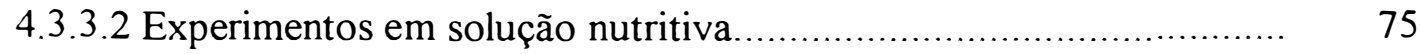

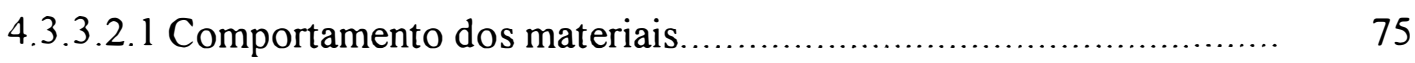

4.3.3.2.2 Cálculo do progresso obtido por seleção............................. 77

4.3.4 Associação entre os experimentos de campo e em casa de vegetação. $\quad 78$

4.4 QUARTA ETAPA: Teste de progênies e estimação de parâmetros

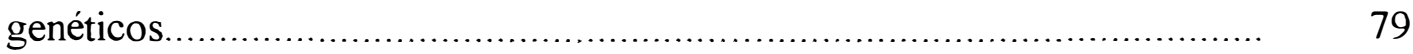

4.4.1 Estimação dos componentes da variância e coeficiente de

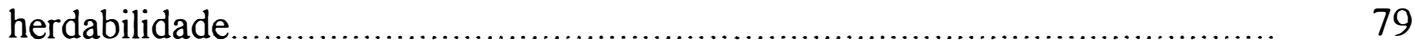

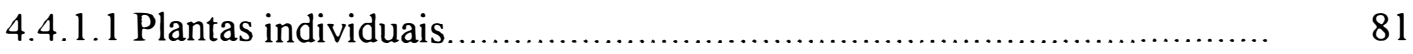

4.4.1.2 Médias de progênies......................................................... 81

4.4.2 Estimação do progresso estimado por seleção............................ 82

4.5 QUINTA ETAPA: Avaliação da utilização de marcadores bioquímicos 82

4.5.1 Isoenzimas: Experimentos preliminares................................ 83

4.5.2 Coloração com hematoxilina: Experimentos preliminares................. 83

4.5.2.1 Experimento 1: Determinação do tempo de exposição ao alumínio.. 83

4.5.2.2 Experimento 2: Otimização dos tempos de lavagem e coloração.... 85

4.5.2.3 Experimento final: Comprovação da eficiência da técnica.............. 86

5 CONSDERAÇÕES FINAIS

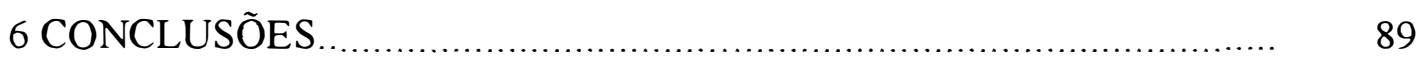

REFERÊNCIAS BIBLIOGRÁFICAS ........................................ 90 
LISTA DE FIGURAS

Página

1 Escala de notas utilizada nos experimentos com hematoxilina................. 34

2 Plantas selecionadas como tolerantes (esquerda) e suscetiveis (direita).....

38

3 Distribuição de freqüências do caráter CLR em plântulas da população SIKALQ

4 Plantas selecionadas como tolerantes (esquerda) e suscetiveis (direita).....

5 Valores médios de Crescimento líquido da raiz (C.LR) de cada grupo de plântulas.

6 Produção líquida de grãos (PL) e acamamento (AC) Piracicaba- Saftinha

7 Produção líquida de grãos (PL) em solo ácido (A) e corrigido (B) Anhumas-Safrinha.

8 Produção líquida de grãos (PL) dos material avaliados Pindamonhangaba -Safrinha.

9 Produção liquida de grãos (PL) e acamamento (AC) Piracicaba- Época normal.

10 Produção líquida de grãos (PL) em solo ácido (A) e corrigido (B) Anhumas- Época normal....

11 Produção líquida (PL) e acamamento (AC) Sete Lagoas- Época normal...

12 Distribuição de freqüências do caráter Crescimento líquido da raiz (C.LR) em progênies de meios irmãos da população SIKALQ.

13 Comportamento médio das populações nos diferentes tempos de exposição ao alumínio.

14 Associação entre o Crescimento líqido da raiz (C.LR) e a coloração com hematoxilina $(\mathrm{CH})$. 


\section{LISTA DE TABELAS}

Página

1 Populações e híbridos utilizados nos experimentos.................................. 21

2 Ambientes utilizados nos experimentos de campo................................... 22

3 Parâmetros agronômicos e fisiológicos avaliados......................................... 23

4 ANAVA e estimativas dos componentes da variância.............................. 28

5 Técnicas de lavagem e coloração testadas.......................................... 35

6 Médias dos material avaliados em solução nutritiva .................................. 42

7 Matéria seca total (MST), Índice de colheita (IC), Produção líquida (PL) e acamamento (AC) Piracicaba- Safrinha ........................................... 44

8 Altura da planta (AP) e espiga (AE) e Ciclo vegetativo (CV) Piracicaba-

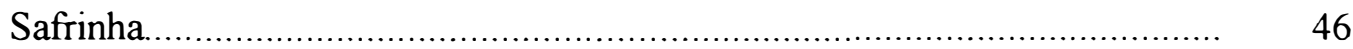

9 Materia seca total (MST) e Índice de colheita (IC) nas duas condições de solo Anhembi - Safrinha......

10 Produção líquida de grãos (PL) e Acamamento (AC) nas duas condições de solo Anhembi - Safrinha.

11 Altura da planta (AP) e espiga (AE) nas duas condições de solo Anhembi Safrinha.

12 Ciclo vegetativo (CV) nas duas condições de solo Anhembi Safrinha.

13 Produção líquida (PL), Altura da planta (AP) e espiga (AE) e acamamento (AC) Pindamonhangaba - Safrinha

14 Matéria seca total (MST), Índice de colheita (IC), Produção líquida (PL) e acamamento (AC) Piracicaba- Época normal..

15 Altura da planta (AP) e espiga (AE) e Ciclo vegetativo (CV) PiracicabaÉpoca normal.

16 Materia seca total (MST) e Índice de colheita (IC) nas duas condições de solo Anhembi - Época normal. 
17 Produção líquida de grãos (PL) e Acamamento ( $\mathrm{AC}$ ) nas duas condições de solo Anhembi - Época normal.................................................... 66

18 Altura da planta (AP) e espiga (AE) nas duas condições de solo Anhembi -

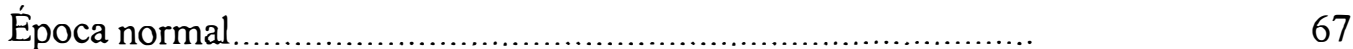

19 Ciclo vegetativo (CV) nas duas condições de solo Anhembi - Época normal.

20 Produção líquida (PL), Altura da planta (AP) e espiga (AE) e acamamento (AC) Sete Lagoas - Época normal.................................. 71

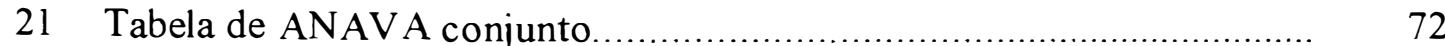

22 Produção líquida média dos material avaliados em todos os ambientes (MTA), nos ambientes de alta produtividade (MAAP), de produtividade intermediaria (MAPI) e baixa produtividade (MAPB)

23 Área foliar (AF), Peso fresco de raiz (PFR) e Peso seco de raiz (PSR) no experimento em vasos com solo álico............................................. 74

24 Crescimento líquido da raiz (CLR) em solução nutritiva........................... 76

25 Associação entre Produção líquida (PL) medida no campo com Crescimento líquido da raíz (CLR), Área foliar (AF), Peso fresco da raiz (PFR) e Peso seco da raiz (PSR) medidos em casa de vegetação................ 78

26 Tabela de ANAVA para plantas individuais........................................... 80

27 Tabela de ANAVA do Experimento 1 de coloração com hematoxilina........ 85

28 Valores médios de Crescimento liquido da raiz (CLR) e coloração com hematoxilina $(\mathrm{CH})$ e correlação fenotipica existente entre elas 


\title{
COMPARAÇÃO DE DUAS METODOLOGIAS DE SELEÇÃO NO DESENVOLVIMENTO DE POPULAÇÕES DE MILHO (Zea mays L.) TOLERANTES A SOLOS ÁCIDOS.
}

\author{
Autor: CARLOS DANIEL GIAVENO \\ Orientador: Prof. JOSÉ BRANCO DE MIRANDA FILHO
}

\section{RESUMO}

Este trabalho teve como principal objetivo comparar a capacidade de detectar tolerância a acidez do solo de duas metodologias de seleção ao nivel de plântula e como objetivos secundarios estudar o tipo de herança do caráter e avaliar a possibilidade de utilizar marcadores bioquímicos na seleção de genótipos contrastantes. Foi realizado um ciclo de seleção divergente, utilizando solução nutritiva e vasos com solo álico. As populações obtidas foram comparadas em experimentos de campo e em casa de vegetação. Foi estimando o coeficiente de herdabilidade em progênies de meio-irmaos em solução nutritiva e foram avaliados sistemas isoenzimáticos e a coloração com hematoxilina como possiveis marcadores. Em todos os experimentos as populações tolerantes foram superiores às suscetiveis e a selecionada em vasos foi superior à obtida utilizando solução nutritiva. O coeficiente de herdabilidade de plantas individuais e de médias de progênies foram 0,75 e de 0,84 evidenciando a presença de um caráter quantitativo com efeitos aditivos e não aditivos. Nenhum dos sistemas isoenzimáticos avaliados apresentou associação aceitável com a tolerância ao alumíno. Já a coloração com hematoxilina foi eficiente na discriminação dos genótipos apresentando uma correlação negativa com o crescimento da raiz em solução nutritiva de 0,82 . 


\title{
COMPARISON BETWEEN TWO SCREENING APPROACHES IN THE DEVELOPMENT OF ACID SOIL TOLERANT MAIZE (Zea mays L.) POPULATIONS
}

\author{
Author: CARLOS DANIEL GIAVENO \\ Adviser: Prof. JOSÉ BRANCO DE MIRANDA FILHO
}

\section{SUMMARY}

The principal objective of this work was the comparison of the efficiency between two screening approaches for tolerance to acid soil at seedling stage as well as the study of the inheritance and the evaluation the feasibility for the utilization of biochemical markers to select tolerant genotypes as secondary objectives. One cycle of divergent selection was carried out, using nutrient solution and pots filled with acid soil. The populations were compared both in field and greenhouse trials. The coefficient of heritability was estimated using half-sib progenies in nutrient solution. Isozymes and hematoxilyn staining were availed as possible biochemical markers. In all trials, the selected tolerant populations were better than the sensitives and the population selected in acid soil was better than the selected in nutrient solution. The estimated coefficient of heritability at individual plant and progeny mean levels were 0.75 and 0.84 . These result indicate the quantitative nature of the trait with an important additive component. None of the isozyme systems show an acceptable association with tolerance. Hematoxylin staining is a useful procedure for selecting Al-tolerant seedlings and it shows a negative high correlation with root growth in nutrient solution of 0.82 . 


\section{1- INTRODUÇÃO}

O milho é considerado o cereal mais importante na América Latina e África e um dos mais importantes no mundo. No Brasil, a área cultivada supera os 13 milhões de hectares, com uma produção de 34 milhões de toneladas anuais. Este rendimento é considerado baixo, não atingindo a média de 3 toneladas por hectare. Esta baixa produtividade deve-se, principalmente à baixa utilização de corretivos e adubos e ao ataque de pragas e doenças. Embora o melhoramento genético tenha permitido superar a maior parte dos problemas de produção, ainda persistem alguns como a sensibilidade da cultura à acidez do solo e ao efeito de toxidez produzido pelo alumínio e manganês que os pesquisadores estão tentando solucionar. Pandey et al. (1994 a), apontaram a importância do melhoramento genético para tolerância a alumínio em milho, uma vez que quase 8 milhões de hectares no mundo são cultivados sob condições de acidez.

O principal problema da produção agrícola em solos ácidos é que normalmente eles apresentam altos niveis de alumínio e manganês, assim como, uma marcante deficiência de fósforo devido ao processo de imobilização.

A toxidez produzida pelo alumínio nas plantas foi muito estudada por Black (1967), que concluiu que essa toxidez se manifesta como um conjunto de sintomas onde o principal fator é a diminuição do desenvolvimento radicular, devido a uma marcante 
inibição do crescimento e da divisão celular. As plantas sensiveis ao alumínio apresentam raizes curtas, grossas e com numerosas raizes laterais não desenvolvidas, aumentando a suscetibilidade à seca devido à diminuição na capacidade de absorção de água. Todos esses fatores conduzem a uma queda sensivel na potencialidade de produzir altos rendimentos de grãos por hectare.

Nos últimos anos, a redução nos rendimentos evidenciados na cultura de milho devido à toxidez produzida pelo aluminio e a ampliação da fronteira agricola brasileira para solos do cerrado, têm sido uma das maiores preocupações tanto para produtores como pesquisadores, o que tem estimulado estudos mais intensos em relação às distintas alternativas de solução do problema. Assim, foram desenvolvidos trabalhos para estabelecer os tipos, quantidades e formas de aplicação mais adequadas de corretivos e adubos, os que conseguem solucionar parcialmente o problema principalmente em subsolos fortemente ácidos, já que existe uma marcante limitação na capacidade de corrigir a acidez mais profundamente no perfil do solo.

Outra alternativa é a obtenção de materiais que apresentam uma maior adaptação a essas condições de solo, o que poderia permitir uma melhor eficiência na utilização das técnicas de calagem e adubação disponiveis

A obtenção de materiais tolerantes ao aluminio exige a realização de ensaios de campo, os quais apresentam um alto custo em tempo e dinheiro investido. Os experimentos de campo possuem a vantagem de representar melhor as condições naturais, porém apresentam o inconveniente de serem demorados devido à necessidade de conduzir o experimento até o final do ciclo e de sofrer a influência de fatores ambientais não controláveis.

Há diferentes alternativas para solucionar esse problema. Uma delas é a realização de tarefas de seleção rápida sob condições ambientais controladas que permitam avaliar um grande número de genótipos, e outra é a utilização de seleção assistida por diferentes tipos de marcadores. 
Devido a importância da espécie e do problema, o presente trabalho baseia-se na hipótese de que é possivel desenvolver populações de milho tolerantes a acidez do solo e à toxidez produzida pelo aluminio, e para isso os seguintes objetivos foram apontados:

Objetivo principal:

- Comparar a capacidade de detectar e selecionar genótipos tolerantes entre duas metodologias apropriadas amplamente utilizadas .

Objetivos secundários:

- Estimar o coeficiente de herdabilidade do caráter tolerância a alumínio e calcular o ganho esperado por seleção.

- Avaliar a possibilidade da utilização de marcadores bioquímicos para detectar genótipos tolerantes e sua possivel aplicação em programas de seleção rápida.

- Estabelecer o tipo de associação existente entre os experimentos de campo e casa de vegetação. 


\section{REVISÃO DE LITERATURA}

\subsection{Solos ácidos e a produção vegetal}

Os solos das regiões tropicais úmidas sofrem, normalmente um processo lento de acidificação produzido tanto pelo material de origem, como pelo uso agrícola ao que estão submetidos. Os solos naturalmente ácidos são característicos de regiões que apresentam um material basal que deu origem à formação de hidróxidos de aluminio e de argilas pouco desenvolvidas do tipo das gibsitas. Em geral estes solos são normalmente pobres em nutrientes, e portanto apresentam na capacidade de troca iônica (C.T.C.) quantidades excessivas de hidrogênio (Hayes, 1991). Outro tipo de solos ácidos, são aqueles que vão sofrendo um processo de acidificação lenta, produzido tanto pelo translado de substâncias ácidas desde a atmosfera, como por uso agrícola inadequado que conduz a uma extração excessiva de bases ou à utilização de quantidades excessivas de adubos, em especial os nitrogenados.

Segundo Uexkül \& Mutert (1995), a maior parte dos solos ácidos do mundo encontram-se em regiões tropicais úmidas. De fato, mais de $43 \%$ da superficie de solos tropicais cultiváveis no mundo são classificados como ácidos, abrangendo cerca de $80 \%$ dos solos das regiões tropicais da América do Sul (Pandey et al, 1994a). A principal região tropical agrícola da América do Sul, que apresenta solos com marcantes problemas de acidez e toxidez por elementos, é a região do cerrado no Brasil. Região que ocupa aproximadamente 183 milhões de hectares, representando $20 \%$ da superficie do pais (Malavolta et al., 1977). 
Normalmente, os solos ácidos apresentam altos niveis de elementos que são tóxicos para a maioria das culturas, como por exemplo o alumínio e o manganês. $\mathrm{O}$ alumínio é o metal mais abundante na crosta terrestre, que em solos neutros ou levemente ácidos, se apresenta sob formas não tóxicas para as plantas. $\mathrm{Na}$ medida que os solos tornam-se mais ácidos, as formas tóxicas são liberadas afetando seriamente a produção, podendo até produzir a morte de plantas suscetiveis (Kochian, 1995).

\section{2- Efeito do alumínio nas plantas}

Black (1967) foi um dos primeiros a estudar a toxidez produzida pelo alumínio nas plantas, concluindo que essa toxidez se manifesta como um conjunto de sintomas, onde a inibição do desenvolvimento radicular é o mais importante. Quando as raizes são submetidas a uma situação de estresse por alumínio, as células mais novas da epiderme e do tecido cortical do ápice da raiz transformam-se no sítio primário especifico de toxidez (Wagatsuma et al., 1995).

Os primeiros trabalhos apontavam um efeito marcante de inibição da divisão celular, baseados principalmente, na observação ao microscópio de uma grande quantidade de células binucleadas e na interrupção do processo de mitose nas raizes das plantas suscetiveis (Clarkson, 1965). Tais observações foram confirmadas posteriormente por outros autores ( Wallace \& Anderson, 1984; Kochian, 1995).

Conforme apontado por Wallace \& Anderson (1984), em raizes que se desenvolvem sob estresse, há um efeito do alumínio sobre o processo de divisão celular devido a uma interação direta do alumínio com a cromatina no núcleo e uma inibição da sintese de DNA, porém esse efeito seria posterior à inibição do crescimento e portanto não pode ser considerado o principal fator responsável. Hoje, considera-se que a interrupção do crescimento radicular é devida ao efeito inicial do alumínio na redução da expansão celular e que a diminuição na divisão celular seria um efeito posterior 
(Kochian, 1995). O efeito sobre a extensão celular pode ser explicado em função da marcante capacidade do aluminio de se ligar a compostos pécticos afetando a extensibilidade e permeabilidade da parede. O aluminio não afeta unicamente à parede celular, mas também à membrana plasmática, diminuindo a absorção de cálcio (Huang, et al., 1992; Rengel \& Elliot, 1992) e de potássio (Gassmann \& Schroender, 1994) por bloqueio de canais específicos, e aumentando a produção de calosa, responsável pelas deformações nas raizes (Wissemeier, et al. 1992; Zhang, et al., 1994).

$\mathrm{O}$ efeito de deficiência de cálcio provocado pelo aluminio, afeta diretamente o processo de formação e ruptura dos microtúbulos de celulose, sendo o principal responsável pela falência na elongação celular (Kochian, 1995).

\section{3- Mecanismos de tolerância ao alumínio presentes nas plantas superiores}

A tolerância ao aluminio presente nas plantas superiores pode ser dividida em mecanismos que facilitam a exclusão do alumínio das células da ponta da raiz, e em mecanismos que conferem a capacidade de tolerar os efeitos do alumínio dentro do simplasto celular (Taylor, 1988). Muitos mecanismos têm sido propostos na literatura, sendo muitos deles especulativos e sem fortes evidências experimentais (Kochian, 1995).

Segundo Miyasaka et al. (1991), um dos mecanismos de exclusão presentes nas plantas é a liberação de ácidos orgânicos induzida pela presença do aluminio. Esses autores reportaram que plantas tolerantes de feijoeiro liberavam 70 vezes mais citrato que as susceptiveis. Delhaize et al. (1993) observaram que ocorre no ápice da raiz de trigo, uma liberação de ácidos orgânicos tais como citrato e malato induzida pela presença do aluminio. Esses autores encontraram uma alta correlação entre a liberação de ácidos, resistência ao alumínio e exclusão do alumínio do ápice radicular, o que poderia ser explicado pela capacidade do malato em proteger a raiz formando quelatos com o alumínio. Há na atualidade uma série de evidências de que a liberação de malato só é 
estimulada pela presença de aluminio, e que essa liberação só acontece no ápice da raiz e que aplicações externas de malato protegem as raizes das plantas susceptiveis.

Pellet et al. (1994) citados por Kochian (1995), reportaram uma importante liberação de citrato em cultivares resistentes de milho, sugerindo que esse seria o principal mecanismo da espécie para tolerar os efeitos do alumínio. Os mecanismos que permitem as plantas detectar a presença do aluminio e liberar os ácidos orgânicos que estão acumulados no simplasto permanecem ainda desconhecidos (Kochian, 1995).

Outro mecanismo bastante estudado é a exclusão do $\mathrm{Al}$ por modificação do $\mathrm{pH}$ da rizosfera. A hipótese de que uma modificação no $\mathrm{pH}$ da rizosfera poderia ser a barreira que permitiria a exclusão do alumínio do ápice foi muito estudada, embora poucas evidências experimentais contribuiram para sustentar esse modelo que ainda hoje é considerada como uma das alternativas possiveis. Quase todos os estudos publicados baseiam-se na medição das alterações no $\mathrm{pH}$ na solução nutritiva, o qual é sabido que está sob a influência da raiz completa e não só do ápice que é considerado o principal ponto de ação do alumínio. Miyasaka et al. (1989) utilizando a técnica de microeletrodos, conseguiram estabelecer a falta de modificações no $\mathrm{pH}$ na rizosfera na região da ponta da raiz, em cultivares contrastantes de trigo submetidos a $\mathrm{Al}$.

Segundo Lindberg (1990) a possibilidade de encontrar em algumas plantas um mecanismo que permitisse eliminar o alumínio do simplasto foi desconsiderada no início das pesquisas. Isso aconteceu devido ao fato de que o alumínio se apresenta na forma mais tóxica $\left(\mathrm{Al}^{+\mathbf{3}}\right)$ quando está em soluções com $\mathrm{pH}$ inferior a 5 e o citossol celular normalmente apresenta valores de $\mathrm{pH}$ entre 7 e 7,5. Nesses valores de $\mathrm{pH}$, ocorre a formação de complexos de alumínio não tóxicos. Estudos recentes demonstraram que o aluminio está presente no citoplasma em concentrações muito baixas (picomolar ou nanomolar) e que essas concentrações seriam suficientes para produzir toxidez.

Há pesquisadores que acreditam na presença de um sistema de eliminação do Al através da membrana para o apoplasto, sugerindo um mecanismo de transporte ativo do tipo ATPase, que utiliza a energia metabólica liberada pela hidrólise do ATP (Taylor, 1988; Lindberg, 1990). 
tipo ATPase, que utiliza a energia metabólica liberada pela hidrólise do ATP (Taylor, 1988; Lindberg, 1990).

Kochian (1995) aponta a presença de um mecanismo de resposta interna. Há na literatura muitas evidências que quando um determinado elemento tóxico, principalmente, um metal pesado $(\mathrm{Cd}, \mathrm{Zn}$ e $\mathrm{Pb})$ consegue atingir o citoplasma celular, ocorre um aumento na síntese de peptídeos de baixo peso molecular, que apresentam a capacidade de formar complexos com o elemento e que cumprem um importante papel no mecanismo de tolerância. Aniol (1984) sugere a presença de um mecanismo em trigo capaz de detectar o $\mathrm{Al}$ e induzir a síntese de proteínas específicas logo após um período de aclimatação. Mais recentemente, Basu et al. (1994) encontraram um aumento na produção de uma proteína de $50 \mathrm{kDa}$ em genótipos tolerantes de trigo.

\section{4- Bases genéticas da tolerância ao alumínio em plantas superiores}

Segundo Kochian (1995) para a maioria das espécies de plantas superiores, a tolerância ao alumínio é considerada um caráter poligênico, controlado por poucos genes de ação maior e muitos genes de efeito modificador. Em geral, a tolerância apresenta-se como um caráter predominantemente dominante.

Foi reportada a presença de variabilidade genética para tolerância ao alumínio em diversas culturas como soja (Spehar \& Makita, 1994; Bianchi et al., 1998), triticale (Zang et al., 1998), feijão (Braccini et al., 1996), alfafa (Dall Agnol et al., 1996) e trigo. Nesta última cultura, Richards et al. (1994) conseguiram isolar, mediante técnicas de biologia molecular dois genes (wali 6 e wali7) responsáveis pela tolerância ao alumínio.

$\mathrm{Na}$ cultura de milho, a presença de variabilidade genética foi reportada por vários autores, que concluíram que há diferenças importantes no comportamento dos materiais avaliados (Furlani et al. 1986; Lopes \& Cox, 1987; Pintro et al. 1995ab; Prioli et al., 1985). 
Segundo Lima et al. (1992), há algumas contradições em relação à herança do caráter tolerância. Assim, alguns autores (Rhue et al., 1978; Miranda et al., 1984; Prioli, 1987) concluíram que há um ou poucos genes envolvidos no caráter, enquanto que Sawazaki \& Furlani (1987) e Magnavaca (1982) encontraram que o caráter possui uma herança do tipo quantitativa.

Embora a presença de genes responsáveis pela de tolerância ao alumínio em milho tenha sido demonstrada, persiste ainda hoje a discussão de qual seria a região do genoma na qual esses genes estariam localizados. Brondani \& Paiva (1996) encontraram marcadores RFLP associados com a tolerância no cromossomo 2. Já Torres et al (1997) utilizando o mesmo tipo de marcadores estabeleceram a existência de uma região relacionada com a tolerância no cromossomo 8.

\section{5- Melhoramento genético visando tolerância ao alumínio}

Pandey et al. (1994a) destacaram a importância de selecionar os melhores genótipos sob distintas condições de acidez em vários locais, concluindo que a avaliação de um grande número de materiais em condições de campo e em diferentes locais, é um processo muito eficiente, mas que apresenta um custo em tempo e dinheiro muito elevado. Na tentativa de diminuir estes custos, é interessante o ajuste de técnicas em ambientes controlados, sejam câmaras de crescimento ou casas de vegetação que permitam avaliar um grande número de plantas, em um curto período de tempo e com uma eficiência semelhante aos experimentos de campo.

Segundo Campbell et al. (1988), há duas alternativas na realização de uma seleção eficiente ao nível de plântula sob condições controladas. Uma delas seria utilizar vasos com solo ácido natural, característico da região para a qual se pretende desenvolver o material melhorado e a outra seria a utilização de soluções nutritivas de baixa força iônica. Trabalhando com alfafa, esses autores concluíram que as duas metodologias foram 
muito eficientes na deteç̧ão de variabilidade, só que devido ao comportamento diferente das progênies, cada metodologia poderia estar detectando diferentes estratégias de tolerância nas plantas.

Ma et al. (1997) apontaram que a toxidez por alumínio não é o único fator que limita o desenvolvimento das plantas em solos ácidos, e portanto a seleção de plântulas em vasos poderia ser considerada mais adequada. Porém, como o efeito primário do alumínio é a inibição do crescimento radicular e a avaliação das raízes é muito difícil nessas condições, tem-se realizado nos últimos anos muitos estudos utilizando soluções nutritivas. Contudo, há uma certa falta de concordância na literatura em relação aos resultados obtidos por essas duas metodologias de seleção ao nivel de plântula e o comportamento no campo (Edmeades et al., 1991; Mackay et al., 1991)

Urrea-Gómez et al. (1996) realizaram um estudo comparando a eficiência da seleção em casa de vegetação utilizando solução nutritiva e vasos com solo álico, com o ensaio de campo. Concluiram que, para etapas iniciais de um programa de melhoramento, a seleção usando solos com uma saturação de $\mathrm{Al}^{+3}$ moderada (entre $45 \%$ e $60 \%$ ), resultou ser muito mais eficiente e apresentou melhores correlações com o experimento de campo, além de ser uma metodologia simples, de baixo custo e rápida.

Nos últimos anos foram liberados uma série de materiais genéticos obtidos pelas diferentes metodologías disponiveis, que apresentam um comportamento sensivelmente superior aqueles disponiveis no mercado. No Brasil por exemplo foram produzidas, entre outras as variedades IAC Taiúba, liberada pelo Instituto Agronómico de Campinas (IAC, 1994) e a CMS 36 produzida pela EMBRAPA Milho e Sorgo. Na Colômbia, o Centro Internacional de Melhoramento de Milho e Trigo (CIMMYT) liberou nos últimos anos uma série de materiais com marcante tolerância ao alumínio, como as populações SA3 e SA8 (Granados, et al. 1995). Uma destas, a SA3, foi liberada comercialmente pelo ICA da Colômbia sob o nome de SIKUANI V-110 (Granados et al., 1995). 


\section{6- Utilização de seleção assistida por marcadores}

Conforme apontado por Ma et al (1997), todas as avaliações realizadas em ambas metodologias de seleção consomem bastante tempo e resultam pouco adequadas para avaliar um grande número de plântulas. Em resposta a essa necessidade, tem-se proposto outras alternativas como por exemplo a utilização de distintos tipos de marcadores que auxiliem a seleção.

Os primeiros marcadores utilizados até a metade da década de 60 estavam controlados por genes associados a caracteres morfológicos. Estes apresentavam a vantagem de ser facilmente identificáveis como por exemplo cor de flor, morfologia foliar ou albinismo. Embora, os marcadores morfológicos apresentassem facilidade de visualização foram pouco utilizados devido às poucas possibilidades de encontrar associações significativas entre eles e os genes de importância econômica. Posteriormente foram desenvolvidos os marcadores bioquimicos, entre os quais destacam-se as isoenzimas. Estes marcadores representam também a expressão fenotipica, porém apresentam a vantagem de sofrer menos as variações produzidas pelo ambiente, o que é particularmente interessante quando se avaliam caracteres quantitativos. Nas últimas décadas, a técnica da eletroforese de isoenzimas tem sido utilizada amplamente para estabelecer a variação genética existente entre indivíduos de uma mesma espécie (Ferreira \& Gratapaglia, 1995). Tanskeley et al.(1982) apontaram uma característica importante das isoenzimas como é apresentar expressão codominante e ausência total de epistasia, permitindo a identificação exata dos genótipos.

Outra alternativa de marcador bioquímico que poderia ser utilizado para a realização de uma seleção rápida seriam as diferentes técnicas de coloração, como por exemplo, a coloração das raizes por hematoxilina. Segundo Rincón \& Gonzalez (1992) esta técnica pode ser utilizada para a visualização e localização do alumínio, devido à capacidade de produzir uma coloração azul intensa nos tecidos da raiz. Essa reação 
acontece pela oxidação da hematoxilina em presença de $\mathrm{NaIO}_{3}$ em hematina. Este composto em presença de alumínio é capaz de produzir a coloração dos ácidos nucleicos.

A técnica da coloração com hematoxilina foi utilizada por vários autores em diferentes culturas como trigo (Polle et al., 1978; Carver et al., 1988; Rincón \& Gonzales, 1992; Tice et al., 1992), soja (Fonseca Jr. 1982; Fonseca Jr. et al., 1982; Spehar \& Makita, 1994), feijão (Braccini et al., 1996) e milho (Cançado, 1997).

Embora a técnica de electroforese de isoenzimas esteja sendo muito utilizada por ser econômica e simples, ela apresenta como principal desvantagem o fato de que cobre unicamente a parte do genoma que se expressa, o que reduz as possibilidades de se encontrar marcadores associados a caracteres de interesse econômico. Com o advento da biologia molecular surgiram, nos últimos anos, uma série de marcadores capazes de detectar polimorfismo genético diretamente ao nível do ADN. Conforme apontado por Ferreira \& Gratapaglia (1995) há uma série de marcadores moleculares disponíveis para a pesquisa como por exemplo o RFLP ("Restriction Fragment Length Polymorphism"), o RAPD ("Random Amplified Polymorphism DNA") e microssatélites, capazes de utilizar todo o genoma vegetal.

\section{- Utilização de germoplasma exótico em programas de melhoramento}

Do ponto de vista de um programa de melhoramento genético, o germoplasma exótico poderia ser definido de diferentes formas. A definição mais simples é a apontada por Lonnquist (1974) que o define como aquele material genético originário de uma área diferente da qual vai ser utilizado. Já Hallauer (1978) considera germoplasma exótico todas as fontes de germoplasma que não estão prontamente disponíveis para um programa de melhoramento e que precisam de um processo de adaptação às novas condições ambientais. 
Segundo Santos (1985), podem ser considerados como germoplasma exótico de milho as populações, raças, hibridos e linhagens, desde que sejam originários de um ambiente diferente daquele onde serão utilizados. Em geral os materiais exóticos poderiam formar dois grupos. Um deles composto por germoplasma de ampla base genética, que podem ser utilizados no melhoramento de populações e o outro formado por linhagens endogâmicas de base genética estreita, as quais podem ser utilizadas na produção de hibridos ou na sintese de novas populações (Paterniani, 1967)

O germoplasma exótico pode ser utilizado diretamente, ou mediante o cruzamento com materiais adaptados. Normalmente, o comportamento per se do material exótico é baixo devido à falta de aclimatação às condições ambientais. Essa situação leva à necessidade de um processo de adaptação baseado no cruzamento com material adaptado e posteriores ciclos de seleção recorrente com baixa intensidade de seleção, visando aumentar a frequêencia de genes favoráveis (Hallauer \& Miranda Filho, 1988).

Numerosos estudos foram realizados objetivando estabelecer a melhor participação percentual do germoplasma exótico em programas de melhoramento. Em geral os autores concluem que a melhor proporção de exóticos varia entre 25 e $50 \%$ (Crossa \& Gardner, 1987; Albrecht \& Dudley, 1987). Segundo Bridgeds \& Gardner (1987), as populações com $25 \%$ de material exótico poderiam ser mais adequadas quando o comportamento da população adaptada é sensivelmente superior. Já as populações com $50 \%$ de exótico podem ser interessantes em programas tanto de curto como de longo prazo, quando o desempenho do germoplasma exótico é equivalente ao do material adaptado, ou quando a superioridade deste ultimo é devida à presença de genes principais.

A utilização de germoplasma exótico nos diferentes programas de melhoramento de milho no Brasil tem desempenhado um papel muito importante. A utilização de materiais exóticos com muito sucesso foi reportada por vários autores (Moro, et al., 1981; Miranda Filho, 1985; Paterniani, 1990; Miranda Filho, 1992; Nass, 1992; Regitano Neto et al., 1997). 


\section{MATERIAL E MÉTODOS}

Devido à amplitude dos objetivos, o presente trabalho foi realizado nas seguintes etapas:

PRIMEIRA ETAPA: Realização do estudo de variabilidade utilizando solução nutritiva e vasos com solo álico e seleção das plantas tolerantes e suscetíveis segundo o esquema de seleção divergente.

SEGUNDA ETAPA: Obtenção das novas populações e das progênies de meios irmãos.

TERCEIRA ETAPA: Comparação do comportamento das populações obtidas em relação à original e às testemunhas.

QUARTA ETAPA: Teste de progênies e estimação do coeficiente de herdablidade e ganho esperado por seleção.

QUINTA ETAPA: Ajuste das técnicas e estabelecimento de marcadores bioquímicos, utilizando sistemas isoenzimáticos e coloração com hematoxilina . 


\subsection{PRIMEIRA ETAPA: Estudo de variabilidade e seleção}

\subsubsection{Material}

Para a realização da primeira etapa foram utilizados três materiais: a população SIKALQ (50\% de SIKUANI e 50\% de EPB2-3A) e os híbridos simples DINA 766 (testemunha tolerante) e MITLA 9560 (testemunha suscetivel).

A população base foi desenvolvida no programa de melhoramento de milho da ESALQ-USP, visando incorporar a tolerância ao aluminio mediante o cruzamento introgressivo de SIKUANI ICA V-110 na população local EPB2-3A. O material exótico utilizado na introgressão é uma população tropical de grãos amarelos inscrita pelo ICA Colômbia, obtida a partir do material experimental SA3 desenvolvido pelo CIMMYT Cali e recomendado por apresentar alto potencial de rendimento em solos álicos (50-60\% de alumínio e menos de 8 ppm de fósforo) (Granados et al., 1997). A população local foi obtida no Depto. de Genética ESALQ-USP como resultado do cruzamento de duas populações de grãos amarelos (ESALQ PB2 e ESALQ PB3) que apresentam uma marcante adaptação e potencialidade de rendimento (Miranda Filho, comunicação pessoal).

As testemunhas foram estabelecidas em função dos resultados experimentais apresentados por Furlani (1997).

\subsubsection{Metodologia}

Na primeira etapa do trabalho foram utilizadas duas metodologias de seleção em casa de vegetação. 


\subsubsection{Método 1: Estudo de variabilidade e seleção em solo álico}

O tipo de solo utilizado foi um Lattossolo vermelho escuro coletado na Estação Experimental da EMBRAPA Milho e Sorgo em Sete Lagoas MG, caracterizado por apresentar pH de 4,2, 9 ppm de fósforo e $53 \%$ de saturação com alumínio.

O solo utilizado foi coletado ao acaso a partir de 20 pontos de amostragem. Em cada ponto o solo foi coletado manualmente, numa superficie de aproximadamente 0,30 $\mathrm{m}^{2}$, nas profundidades de $0-20 \mathrm{~cm}$ e $20-40 \mathrm{~cm}$ e colocados em sacos diferentes. Posteriormente, o solo de todos os sacos pertencentes a cada profundidade foi peneirado para eliminar residuos orgânicos e uniformizar o tamanho dos torrões e misturadao manualmente com a finalidade de obter um material o mais homogêneo possivel.

Foram utilizados vasos plásticos com capacidade aproximada de 6,75 litros (15 $\mathrm{cm} \times 15 \mathrm{~cm} \times 30 \mathrm{~cm}$ ) que permitiram avaliar 20 plântulas por vaso. Em cada vaso foi colocado metade de solo de $20-40 \mathrm{~cm}$ e completado com solo de $0-20$ com a finalidade de recompor a estrutura original de um solo de cerrado.

Foram avaliadas um total de 1760 plantas, sendo 1720 da população SIKALQ, 20 da testemunha tolerante e 20 da testemunha suscetível .

As sementes foram colocadas em caixas de germinação, a $27{ }^{\circ} \mathrm{C}$ durante 30 horas e molhadas com água destilada. As sementes que apresentaram o comprimento da radicula de aproximadamente $0,3-0,5 \mathrm{~cm}$, foram transplantadas para os vasos seguindo a metodologia proposta por Urrea-Gómez et al. (1996).

Os vasos foram colocados em casa de vegetação e irrigados periodicamente com água de torneira. A duração do experimento foi de 15 dias. No final do ensaio as plantas foram extraidas dos vasos mediante lavagem com água a pressão. Após a lavagem das raizes, foram avaliados visualmente o desenvolvimento da parte aérea e das raizes e selecionadas as duas melhores plantas (tolerantes) e as duas piores (suscetiveis) tanto da parte aérea quanto do sistema radicular. A avaliação visual foi feita com uma escala de notas de 0 (tolerante) até 5 (suscettivel). 
Foram selecionadas 200 plantas de cada grupo, utilizando-se uma intensidade de seleção de $12 \%$. Cada uma dessas plantas foi colocada em saquinho plástico com solo corrigido, tratadas com fungicida e, posteriormente, transplantadas no campo.

\subsubsection{Método 2: Seleção em solução nutritiva.}

A seleção das plantas baseou-se na tolerância a acidez e toxidez ao alumínio quando avaliadas em solução nutritiva de baixa força iônica. Esta etapa foi desenvolvida

na seção de milho do Instituto Agronômico de Campinas (IAC) recebendo assistência técnica do Dr. Pedro Roberto Furlani.

A quantidade total de plantas avaliadas foi a mesma do método 1. Essas plantas foram colocadas em 5 caixas de plástico de 30 litros de capacidade, pintadas de preto do lado de fora para evitar o desenvolvimento de algas e manter um ambiente escuro para as raízes .

Cada caixa recebeu aeração permanente e independente através de um tubo de plástico com aerador de material poroso no extremo. Para manter as plantas suspensas na solução nutritiva, foram utilizadas bandejas brancas de PVC, de $8 \mathrm{~mm}$ de espessura, contendo um total de 386 furos.

Para facilitar a obtenção de plântulas normais com raizes retas, as sementes foram colocadas em folhas de papel de germinação, colocando-se aproximadamente 20 sementes por folha. Cada folha foi posteriormente dobrada formando um rolo e umedecida com água destilada. Esses rolos foram colocados em uma câmara de germinação durante 72 horas a $27^{\circ} \mathrm{C}$. As raízes secundárias das plântulas normais, foram cortadas manualmente, mantendo unicamente a raiz principal a qual foi medida para obter o valor de comprimento inicial (CIRP) .

A duração do experimento foi de 7 dias e cada planta foi avaliada utilizando a solução nutritiva proposta por Furlani \& Furlani (1988). No final do experimento a raiz foi novamente medida (CFRP) e as plântulas foram identificadas individualmente com 
uma etiqueta auto-adesiva. As plântulas foram posteriormente colocadas em uma caixa com solução nutritiva sem alumínio até o momento de transplante no campo das plantas selecionadas.

O processo de seleção foi realizado em função do parâmetro CLR (Crescimento Liquido da Raiz) que representa o desenvolvimento da raiz principal sob estresse.

$$
C L R=\frac{(C F R P-C I R P)}{D E}=\mathrm{mm} \mathrm{dia}^{-1}
$$

O CLR foi calculado pela diferença entre o comprimento final (CFRP) e o comprimento inicial da raiz principal (CIRP), dividido pela duração do experimento (DE) expresso em dias.

Foi calculado o valor de CLR para cada uma das plantas da população SIKALQ e das testemunhas. Foi realizado um processo de seleção divergente, escolhendo as 200 plântulas que apresentaram um CLR superior à testemunha tolerante e a mesma quantidade com CLR inferior à testemunhas suscetivel, segundo uma intensidade de seleção de aproximadamente $12 \%$. As plantas selecionadas foram transplantadas no campo, em lote isolado, sob condições de solo corrigido com calagem e adubação de nitrogênio, fósforo e potássio.

\subsubsection{Delineamento experimental utilizado}

Para a seleção de plantas tolerantes e suscetiveis, os materiais foram colocados na casa de vegetação segundo um esquema de seleção estratificado. Cada caixa ou grupo de vasos foi considerada como um estrato e as plantas representativas da população base e das testemunhas foram distribuídos ao acaso.

Devido à morte de plantas, principalmente as altamente suscetiveis, os resultados dos experimentos foram analisados com o procedimento GLM (SAS, 1994). 


\subsection{SEGUNDA ETAPA: Cruzamentos no campo.}

\subsubsection{Obtenção das novas populações.}

\subsubsection{1- Material}

As plântulas tolerantes e suscetiveis, selecionadas nos vasos com solo álico (Método 1) e na solução nutritiva (Método 2) foram transplantadas em lotes isolados sob condições de solo corrigido com calagem e adubação.

\subsubsection{2-Metodologia}

No momento do transplante em lote isolado, todas as plantas foram tratadas com o fungicida sistêmico Benlate, pertencente ao grupo químico Benzimidazol (Metil-1butilcarbamoil-2-benzimidazol carbamato) com uma dose de 150 gramas para cada 100 litros de água. As plantas receberam irrigação diária localizada durante a primeira semana logo após o transplante com a finalidade de reduzir as falhas. Ao atingir a maturidade, foram colhidas as espigas de todas as plantas e armazenadas para uniformizar o conteúdo de umidade em aproximadamente $14 \%$. Nesse momento foi realizada a separação dos grãos, os quais foram misturados em quantidades equivalentes com a finalidade de obter populações balanceadas, em relação à participação percentual de cada planta. As sementes de cada população foram tratadas com o inseticida K-Obiol, pertencente ao grupo Deltamethinas, com uma dose de 500 gramas por tonelada de semente e armazenadas em câmara fria.

\subsection{2- Obtenção das progênies de meios irmãos}

\subsubsection{1- Material}

Aproximadamente 400 sementes da população original (SIKALQ) foram semeadas em lote isolado, sob condições de solo corrigidas. 


\subsubsection{2-Metodologia}

As sementes foram tratadas com Benlate aplicando uma dose de 200 gramas por cada 100 quilos de sementes. No momento da colheita foram escolhidas ao acaso, 100 plantas. De cada planta foi tomada uma única espiga, que foi colhida individualmente e os grãos colocados num saco de papel, dando origem às familias de meios irmãos. As sementes foram tratadas com K-Obiol e colocadas em câmara fria.

\subsection{TERCEIRA ETAPA: Comparação das populações obtidas pelas duas metodologias de seleção.}

Para conhecer o comportamento das populações obtidas durante o processo de seleção per se e compará-las com à original e às testemunhas foram realizados dois tipos de experimentos: de campo e em casa de vegetação.

Os experimentos de campo foram realizados com o objetivo de avaliar o comportamento desses materiais quando submetidos a condições ambientais contrastantes e estudar o efeito do estresse por aluminio sobre determinados parâmetros agronômicos e fisiológicos.

Os experimentos em condições controladas foram realizados para, além da comparação dos materiais, estabelecer o grau de associação entre os resultados de cada metodologia de avaliação de plântulas com os obtidos nos experimentos de campo. No caso da avaliação em solução nutritiva, houve outro objetivo que foi medir o progresso realmente obtido por seleção e compará-lo com o progresso estimado na ETAPA 4.

\subsubsection{MATERIAL}

As populações utilizadas tanto nos experimentos de campo quanto em ambiente controlado estão identificadas na Tabela 1. 
Tabela 1 - Populações e híbridos utilizados nos experimentos.

\begin{tabular}{|c|c|c|}
\hline Material & Nome & Caracterização \\
\hline 1 & EPB2-3A & $\begin{array}{l}\text { População local que recebeu o cruzamento introgressivo de } \\
\text { SIKUANI. }\end{array}$ \\
\hline 2 & SIKALQ & População resultante do cruzamento introgressivo. \\
\hline 3 & C-1 T SN & Ciclo 1 Tolerante (solução nutritiva) \\
\hline 4 & C-1 S SN & Ciclo 1 Suscetível (solução nutritiva) \\
\hline 5 & C-1 T SA & Ciclo 1 Tolerante (solo álico) \\
\hline 6 & C-1 S SA & Ciclo 1 Suscetível (solo álico) \\
\hline 7 & TT & Testemunha tolerante (DINA 766) \\
\hline 8 & TS & Testemunha suscetivel (MITLA 9560) \\
\hline
\end{tabular}

\subsubsection{EXPERIMENTOS DE CAMPO}

\subsubsection{Ambientes de avaliação}

Foram utilizadas duas épocas de plantío e quatro locais em cada época (Tabela 2). As épocas utilizadas foram:

- Safrinha: Caracterizada pelo plantio de culturas de ciclo primavera-verão fora dessas estações do ano. A cultura de milho safrinha tem ganhado importância nos últimos anos no Estado de São Paulo e outros estados brasileiros como alternativa de substituição de culturas de inverno menos rentáveis. O milho cultivado em safrinha caracteriza-se por sofrer uma série de fatores de estresse ambiental como baixas temperaturas, seca e aumento na incidência de algumas doenças, especialmente as de origem viral (complexo enfezamento). 
-Época normal: Caracterizada pelo plantio da cultura de milho na data ótima de semeadura, onde as condições climáticas são favoráveis ao desenvolvimento e as maiores produtividades são obtidas.

Tabela 2 - Ambientes utilizados nos experimentos de campo.

\begin{tabular}{|c|c|c|c|}
\hline Produtividade & Nível de $\mathrm{Al}^{+3}$ & Solo corrigido & Localização \\
\hline Alta & $\operatorname{sem~} \mathrm{Al}^{+3}$ & $\operatorname{sim}$ & Depto Genética-Piracicaba SP. \\
\hline média alta & $30-35 \%$ sat. & $\operatorname{sim}$ & Faz. Anhembi - Anhumas SP. \\
\hline média baixa & $30-35 \%$ sat. & não & Faz. Anhembi - Anhumas SP. \\
\hline Baixa & $45-50 \%$ sat. & não & $\begin{array}{l}\text { EMBRAPA - Sete Lagoas MG } \\
\text { e IAC- Pindamonhangaba SP. }\end{array}$ \\
\hline
\end{tabular}

No local de alta produtividade o experimento foi conduzido com irrigação e adubação com a finalidade de conhecer o potencial de produção das populações experimentais. Foram aplicados, na linha de plantio, 30 gramas de fertilizante 4-20-20 por metro lineal e posteriormente (7-8 folhas), uréia em cobertura, na mesma quantidade.

No local de média produtividade, foram realizados dois experimentos, um deles sob condições naturais (sem calagem nem adubação) e outro com correção do pH em superficie e adubação ( a mesma quantidade aplicada no local de alta produtividade), com a finalidade de isolar o efeito das características químicas do solo, em especial com diferentes disponibilidades de aluminio, fósforo, potássio, cálcio e magnésio. Nos locais de baixa produtividade não foram realizados os experimentos em condições corrigidas por falta de área disponivel nos campos experimentais tanto do Instituto Agronômico de Campinas como da EMBRAPA.

Em todos os experimentos as sementes foram tratadas com o inseticida sistêmico Thiamethoxam 700WS, pertencente ao grupo dos Neonicotinoides, na 
quantidade de $300 \mathrm{~g}$ de produto por cada $100 \mathrm{~kg}$ de semente com a finalidade de proteger a cultura de insetos sugadores, em especial as cigarrinhas responsáveis pela transmissão de vírus (complexo enfezamento).

\subsubsection{METODOLOGIA}

Todos os experimentos foram conduzidos seguindo um delineamento de blocos completos ao acaso, com quatro repetições. Foram utilizadas parcelas de duas linhas de quatro metros de comprimento, totalizando 40 plantas para cada tratamento por repetição. Além das quatro repetições utilizadas para avaliar produção e caracteres agronômicos, foram utilizados dois blocos adicionais, com parcelas de duas linhas de três metros de comprimento cada uma, as quais foram utilizadas para as tarefas de amostragem para determinação dos parâmetros fisiológicos.

Os materiais foram comparados em função de variáveis agronômicas e fisiológicas (Tabela 3 )

Tabela 3 - Paràmetros agronômicos e fisiológicos avaliados

\begin{tabular}{|c|c|c|c|}
\hline Parâmetros Agronômicos & & Parâmetros fisiológicos & \\
\hline Produção de grãos & $\mathrm{PT}^{1}$ e $\mathrm{PL}^{2}$ & Indice de colheita & IC \\
\hline Altura plantas e espigas & $\mathrm{AP}$ e $\mathrm{AE}$ & Matéria Seca Total & MST \\
\hline Ciclo vegetativo & E-F & Área foliar & $\mathrm{AF}$ \\
\hline Acamamento & $\mathrm{AC}$ & & \\
\hline
\end{tabular}

PT: Produção total. "2PL: Produção líquida.

A produção total de grãos (PT) foi avaliada mediante a colheita de todas as plantas da parcela, as espigas foram debulhadas e a porcentagem de umidade dos grãos $(\% U)$ medida. $\mathrm{O}$ rendimento de cada material em cada repetição foi corrigido para $14 \%$ de umidade. Devido ao fato das parcelas não possuírem o mesmo número de plantas, a 
produção por parcela foi corrigida através do cálculo da covariância para número ideal mediante a utilização do software MSTAT-C.

$\mathrm{O}$ acamamento (AC) foi avaliado mediante a contagem das plantas acamadas por parcela. Essas plantas foram colhidas separadamente para estimar as perdas por acamamento e calcular a produção líquida de grãos (PL) mediante a diferença entre a produção total menos as perdas por acamamento.

As variáveis altura da planta (AP) e da espigas (AE), expressas em centímetros, foram obtidas medindo-se todas as plantas da parcela. Altura da planta foi medida até a primeira ramificação do pendão e altura da espiga até a inserção da primeira espiga (espiga superior).

O ciclo vegetativo $(\mathrm{E}-\mathrm{F})$ foi avaliado mediante apreciação visual, considerandose que o material estava em pleno florescimento quando $50 \%$ das plantas da parcela estavam liberando pólen.

O índice de colheita (IC) foi medido no momento de pré colheita conforme a seguinte metodologia (Donald \& Hamblin, 1976).

$$
I C=\left(\frac{R E}{R B}\right) \times 100=(K g \text { de grão } / K g \text { de matéria seca total }) \times 100
$$

O IC é uma excelente forma de avaliar a eficiência de um determinado material para transformar todo o seu rendimento biológico $(\mathrm{RB})$ em rendimento econômico (RE) ou seja, em produção de grãos, expresso como matéria seca total produzida (MST). Para obter o IC foram coletadas três repetições de cinco plantas representativas de cada parcela e a biomassa total pesada. Posteriormente, foi feita a separação dos principais componentes do rendimento biológico (folhas, caules, palhas, sabugo e grãos) e foram tiradas amostras representativas de cada um deles para obtenção da porcentagem de matéria seca. As espigas foram debulhadas e o peso úmido dos grãos obtido. A porcentagem de matéria seca de cada um dos componentes da fórmula foi obtida mediante o secagem das amostras em estufa a $60{ }^{\circ} \mathrm{C}$ por quatro dias até peso constante. 
No local de alta produtividade, foram utilizadas condições ótimas, com adubação NPK e irrigação periódica. Já nos locais de produtividade intermediária e baixa, a adubação foi feita unicamente nos experimentos em solo corrigido, enquanto aqueles em solo álico não receberam aplicação de nutrientes. Em todos os casos, não foi aplicada irrigação periódica, aplicando-se água unicamente para assegurar o sucesso do experimento.

\subsubsection{EXPERIMENTOS EM CASA DE VEGETAÇÃO}

\subsubsection{Experimento em vasos com solo álico}

\subsection{METODOLOGIA}

Este experimento foi conduzido em casa de vegetação, utilizando-se o mesmo tipo de solo e os mesmos vasos descritos no processo de seleção (Método 1, Etapa 1).

Foram utilizadas dez plantas por material em cada repetição, num delineamento de blocos ao acaso com quatro repetições. A duração do experimento foi de 15 dias e no final do período, as raizes das plantas foram lavadas com água a pressão. Posteriormente, foi separada a raiz da parte aérea e realizadas as medições para cada plântula.

A avaliação da parte aérea foi feita mediante a utilização de um medidor digital de área foliar que fornece a superficie foliar das plantûlas. Nas raizes foram avaliados o peso fresco e seco $\left(72\right.$ horas a $\left.60{ }^{\circ} \mathrm{C}\right)$. Todas essas medições foram realizadas no Laboratório de Fisiologia do Estresse do Departamento de Ciências Biológicas da ESALQ-USP, contando com a assistência técnica do Prof. Dr. Ricardo Ferraz de Oliveira.

Além de comparar o comportamento dos materiais per se e em relação às testemunhas, os dados deste experimento foram utilizados para estabelecer o grau de associação de cada um desses caracteres com a produção total de grãos obtida nos experimentos de campo mediante o coeficiente de correlação de Pearson. 


\subsubsection{Experimento em solução nutritiva}

\subsection{METODOLOGIA}

Este experimento foi realizado utilizando a mesma solução nutritiva (Furlani \& Furlani, 1988) e duração (sete dias) utilizados durante o processo de seleção (Método 2 , Etapa 1) e teste de progênies (Etapa 4). As plântulas foram preparadas e colocadas em caixas de 3,5 litros de capacidade sustentadas por uma placa de isopor de $5 \mathrm{~mm}$ de espessura. Foram avaliadas 20 plântulas de cada tratamento em cada repetição em um delineamento de blocos completos ao acaso com 3 repetições.

O comportamento dos materiais foi avaliado mediante o parâmetro CLR.

O progresso realmente obtido por seleção utilizando o crescimento radicular em solução nutritiva, foi calculado pela diferença no crescimento líquido da raiz nas populações selecionadas como tolerante (C-1 TSN) e suscetivel (C-1 SSN) com a população original (SIKALQ).

Paralelamente os resultados de CLR obtidos neste experimento foram utilizados para estimar o grau de associação entre o caráter com a produção total de grãos obtida nos experimentos de campo mediante o coeficiente de correlação de Pearson.

\subsection{QUARTA ETAPA: Teste de progênies e estimação de parâmetros genéticos}

\subsubsection{Material}

Foram utilizadas 100 progênies de meios irmãos obtidas na etapa 2. 


\subsubsection{Metodologia}

\subsubsection{Estimação dos componentes da variância}

As progênies foram avaliadas em função do caráter CLR nas mesmas caixas, com a mesma solução nutritiva e a mesma duração do experimento, utilizadas no método 2 da primeira etapa.

Devido à quantidade de plantas possíveis de se avaliar por caixa, foram utilizadas 23 plantas nas progênies 1 até 70 e 87 até 100. Enquanto das progênies 71 até 86 foram utilizadas 24 plantas. Devido ao fracasso total na germinação, a progênie número 63 não foi avaliada.

\section{Modelo estatístico}

A estimação dos componentes da variância que permitiram calcular o coeficiente de herdabilidade do caráter CLR, foi realizada tanto ao nível de plantas individuais como de médias de progênies. Essas duas estimativas foram realizadas com a finalidade de conhecer a presença de componentes não aditivos na variância genética. Para isso foi . utilizado o modelo:

$$
Y_{i j k}=m+p_{i}+b_{j}+e_{i j}+d_{i j k}
$$

Onde: $Y_{i j k}$ é o valor da variável, $m$ a media populacional, $p_{i}$ é o efeito das progênies, $b_{j}$ é o efeito da repetição, e ij é o erro experimental e $d_{i j k}$ são as observações dentro da parcela.

Os componentes da variância (Tabela 4), foram estimados segundo o método prático proposto por Hicks (1973). As progênies foram consideradas como aleatórias por terem sido obtidas ao acaso a partir da população de referência SIKALQ 
Tabela 4 - ANAVA e estimativas dos componentes da variância.

\begin{tabular}{|c|c|c|c|c|c|}
\hline C. V. & G.L & S.Q. & Q.M. & F & E.Q.M. \\
\hline Blocos & $r-1$ & $\mathrm{SQ}_{1}$ & $\mathrm{Q}_{1}$ & $\mathrm{Q}_{1} / \mathrm{Q}_{4}$ & \\
\hline Progênies & $n-1$ & $\mathrm{SQ}_{2}$ & $\mathrm{Q}_{2}$ & $\mathrm{Q}_{2} / \mathrm{Q}_{4}$ & $\sigma_{\mathrm{d}}^{2}+\mathrm{k} \sigma_{\mathrm{e}}^{2}+\mathrm{kr} \sigma_{\mathrm{p}}^{2}$ \\
\hline Erro & $(n-1)(r-1)$ & $\mathrm{SQ}_{3}$ & $\mathrm{Q}_{3}$ & $\mathrm{Q}_{3} / \mathrm{Q}_{4}$ & $\sigma^{2}{ }_{d}+k \sigma_{e}^{2}$ \\
\hline Dentro & $(\mathrm{k}-1) \mathrm{nr}$ & $\mathrm{SQ}_{4}$ & $\mathrm{Q}_{4}$ & & $\sigma_{d}^{2}$ \\
\hline Total & nrk - 1 & $\mathrm{SQ}_{j}$ & & & \\
\hline
\end{tabular}

Devido as parcelas não possuírem o mesmo número de plantas e pelo fato de algumas dessas plantas, as mais suscetíveis, terem morrido durante o experimento, os dados das plantas individuais foram analisados utilizando-se o procedimento GLM (SAS, 1994).

Cálculo das variâncias dentro $\left(\sigma_{\mathrm{d}}^{2}\right)$, do erro $\left(\sigma_{\mathrm{e}}^{2}\right)$ e das progênies $\left(\sigma_{\mathrm{p}}^{2}\right)$ para plantas individuais.

$\hat{\sigma}_{\mathrm{d}}^{2}=\mathrm{Q}_{4} \quad \hat{\sigma}_{\mathrm{e}}^{2}=\frac{\mathrm{Q}_{3}-\mathrm{Q}_{4}}{\mathrm{k}} \quad \hat{\sigma}_{\mathrm{p}}^{2}=\frac{\mathrm{Q}_{2}-\mathrm{Q}_{3}}{\mathrm{rk}}$

Devido ao fato de que todas as parcelas não possuiam o mesmo número de plantas, o valor de $k$ foi substituído pela média harmônica.

Para o cálculo das variâncias ao nível de médias de famílias:

$$
\hat{\sigma}_{\mathrm{e}}^{2}=\mathrm{Q}_{3} \quad \sigma_{\mathrm{p}}^{2}=\frac{\mathrm{Q}_{2}-\mathrm{Q}_{3}}{\mathrm{r}}
$$




\subsubsection{Estimação do coeficiente de herdabilidade.}

-Coeficiente de herdabilidade para plantas individuais:

$$
h^{2}=\frac{\sigma_{A}^{2}}{\sigma_{F}^{2}}=\frac{4 \sigma_{p}^{2}}{\sigma_{p}^{2}+\sigma_{e}^{2}+\sigma_{d}^{2}}
$$

-Coeficiente de herdabilidade para médias de parcelas.

$$
h^{2}=\frac{\sigma_{G}^{2}}{\sigma_{F}^{2}}=\frac{\sigma_{p}^{2}}{\sigma_{p}^{2}+\frac{\sigma_{e}{ }^{2}}{r}+\frac{\sigma_{d}^{2}}{k r}}=\frac{Q_{2}-Q_{3}}{Q_{2}}
$$

\subsubsection{3- Estimação do progresso esperado por seleção.}

$$
\mathbf{G}_{\mathbf{s}}=\mathrm{ds} \cdot \mathrm{h}^{2}
$$

O diferencial de seleção (ds) foi calculado mediante a diferença entre a média da população de referência e a média das plantas selecionadas como tolerantes. 


\subsection{QUINTA ETAPA: Avaliação da utilização de marcadores bioquímicos .}

\subsubsection{Isoenzimas: Experimentos preliminares.}

Devido à carência de informação na literatura em relação à utilização de isoenzimas como marcadores bioquímicos para tolerância ao alumínio, foram desenvolvidos uma série de experimentos com a finalidade de estabelecer o melhor protocolo em relação ao tipo de gel, tempo de corrida e tipo e quantidade de tecido da planta a serem utilizados.

\subsubsection{1-MATERIAL}

Como esta foi uma etapa de caráter exploratório, foram utilizadas plântulas das testemunhas ( Dina 766 e Mitla 9560), tentando aproveitar o fato de serem híbridos simples e diminuir as variações dentro de cada material.

\subsubsection{2-METODOLOGIA}

\subsubsection{1- Tipos de géis testados}

Foram testados três tipos de gel (Alfenas et al., 1991):

Para eletroforese horizontal: - Gel de amido e agarose e gel de penetrose. Para eletroforese vertical: - Gel de poliacrilamida.

\section{- Gel de amido e penetrose}

Numa primeira etapa foi testada a possibilidade de utilizar géis combinando 20 gramas de amido e 10 gramas de penetrose, dissolvidos em 250 mililitros de solução tampão. Foram testados três tipos de solução tampão, TC (Tris Citrato) pH 7,5, CM (Citrato de Morfolina) pH 6,1 e AB (litio Borato) pH 8,3. As 30 gramas da mistura 
amido + penetrose foram dissolvidas em $90 \mathrm{ml}$ de tampão dentro de um erlenmeyer de $500 \mathrm{ml}$, os $160 \mathrm{ml}$ restantes foram colocados num forno de microondas até começar a ferver e logo colocado no erlenmeyer sob agitação constante. Esse erlenmeyer foi colocado no forno de microondas durante 2 minutos, retirando-se a cada 15 segundos para agitar. Uma vez que a mistura começou a ferver, foi colocada numa forma de vidro e acrílico de $17 \mathrm{~cm} \times 13 \mathrm{~cm} \times 1,3 \mathrm{~cm}$ (Alfenas et al. 1991)

\section{- Gel de penetrose.}

Com a finalidade de melhorar a definição das bandas, foi testada a possibilidade de utilizar géis de penetrose ao $13 \%$, colocando 32 gramas de penetrose em $250 \mathrm{ml}$ de tampão (Faraldo, 1999), mantendo as mesmas soluções tampão e o mesmo protocolo de preparação do gel descritos para o gel de amido+agarose.

Tanto nos géis de amido + agarose como de penetrose, para um melhor aproveitamento, cada gel foi cortado horizontalmente em 5 fatias resultando na obtenção de 5 sistemas isoenzimáticos diferentes.

\section{- Gel de poliacrilamida}

Foi utilizada a técnica de eletroforese vertical em gel de poliacrilamida descontínuo em gradiente. Esta técnica permite a migração das enzimas através de um gel concentrador e um separador construido em gradiente de $5 \%$ na parte superior e $6 \%$ na inferior. As duas soluções com concentrações diferentes de poliacrilamida utilizadas, que permitiram a obtenção de poros maiores na parte superior e menores na inferior, foram preparadas segundo Silva (2000). 


\subsubsection{2 - Colheita das amostras de tecido.}

Foi avaliada a possibilidade de utilizar amostras de tecidos obtidas tanto do ápice da raiz, quanto de folhas novas em expansão, observando-se o tipo e intensidade da atividade enzimática apresentada por cada uma delas.

\subsubsection{3 - Indução de atividade enzimática pela presença de alumínio}

Com a finalidade de conhecer se a presença de quantidades tóxicas de alumínio na solução nutritiva podem induzir a atividade de algumas isoenzimas, foram realizados testes de indução de curta duração. Para isso, plantas das testemunhas tolerante e suscetivel foram colocadas durante 24 horas em solução nutritiva descrita por Furlani \& Furlani (1988). A mesma quantidade de plantas das testemunhas foram colocadas numa solução nutritiva padrão sem alumínio.

\subsubsection{4 - Intensidade e duração das corridas eletroforéticas}

Foram testadas duas alternativas:

- Rápida: Os géis foram colocados numa câmara fria, a aproximadamente $3{ }^{\circ} \mathrm{C}$ dentro das cubas contendo os respectivos tampões. Nos primeiros 30 minutos da corrida utilizou-se uma intensidade de $20 \mathrm{~mA}$ e $100 \mathrm{~W}$ e posteriormente $40 \mathrm{~mA}$ e $200 \mathrm{~W}$ até completar a corrida dando um tempo total de aproximadamente 6-7 horas.

-Lenta: Devido as características próprias dos géis preparados com tampão $A B$, é possivel fazer uma corrida lenta com uma intensidade constante de 15-20 mA e 80-100 W. O tempo total da corrida é de aproximadamente 10-11 horas. Foi testada a possibilidade de realizar corridas lentas em géis preparados na base de Tampão CM e TC com a finalidade de permitir uma melhor separação das frações .

\subsubsection{5 - Sistemas isoenzimáticos testados.}

Os sistemas isoenzimáticos avaliados tanto nas amostras de tecido de raiz como de folha, corados segundo o protocolo de Alfenas et al., (1991) foram Esterase, $\beta$ 
Esterase, Glucose-6-Fosfato Desidrogenase, Isocitrato Desidrogenase, Malato Desidrogenase, Fosfoglucose Isomerase, Peroxidase, Xiquimato Desidrogenase, Catalase, Fosfatase Ácida, Fosfoglucomutase, Fosfatase Alcalina, Glucose Desidrogenase, Enzima Málica, Manitol Desidrogenase, Aconitase, Alcool Desidrogenase, Glutamato-Oxalacetato Transaminase, Glutamato Desidrogenase, Leucina Amilopeptidase.

A coloração de todos os sistemas avaliados foi realizada com os protocolos descritos por Alfenas et al. (1991)

\subsubsection{Coloração com hematoxilina: Experimentos preliminares.}

Devido à falta de informação disponivel na literatura, os trabalhos foram realizados baseados na metodologia proposta por Cançado (1997), que realizou uma adaptação da metodologia utilizada por Polle et al. (1978).

Foram realizados dois experimentos em câmara de crescimento. O primeiro teve como objetivo estabelecer o melhor momento da realização da avaliação da tolerância, expresso em horas de exposição ao aluminio. O segundo estabeleceu a melhor combinação nos tempos de lavagem pré e pós coloração e de exposição à hematoxilina das raizes.

\subsubsection{Material}

Foram utilizadas sementes de duas populações contrastantes, uma tolerante (CMS 36) e a outra suscetivel (BR 106). 


\subsubsection{2 -Experimento 1: Determinação do tempo de exposição ao alumínio.}

\subsubsection{1 -Metodologia}

As plântulas das duas populações foram obtidas seguindo o mesmo processo descrito no processo de seleção em solução nutritiva (Método 2, Etapa 1). Plântulas com comprimento radicular semelhante foram colocadas em caixas de plástico de 3,5 litros de capacidade contendo solução nutritiva com alumínio (Furlani \& Furlani, 1988). Os períodos de exposição ao alumínio utilizados foram $0,12,24,72,120$ e 168 horas. Ao final de cada período, 20 plântulas de cada população foram retiradas da solução nutritiva e as raízes lavadas com água destilada por 15 minutos e colocadas em um recipiente de vidro com um litro de solução de hematoxilina a $2 \%$ durante 20 minutos. Posteriormente, as raízes foram novamente lavadas com água destilada durante 15 minutos (Cançado,1997). O experimento foi conduzido em câmara de crescimento utilizando temperatura de $24^{\circ} \mathrm{C}$ e um fotoperíodo de 16 horas de luz e 8 horas de escuridão e as populações consideradas como tratamentos em um delineamento inteiramente ao acaso com três repetições. Foi feita uma avaliação visual seguindo uma escala de notas (Figura 1) de 0 (tolerante) até 5 (suscetível). Esses resultados foram analisados utilizando o procedimento ANOVA (SAS,1994).

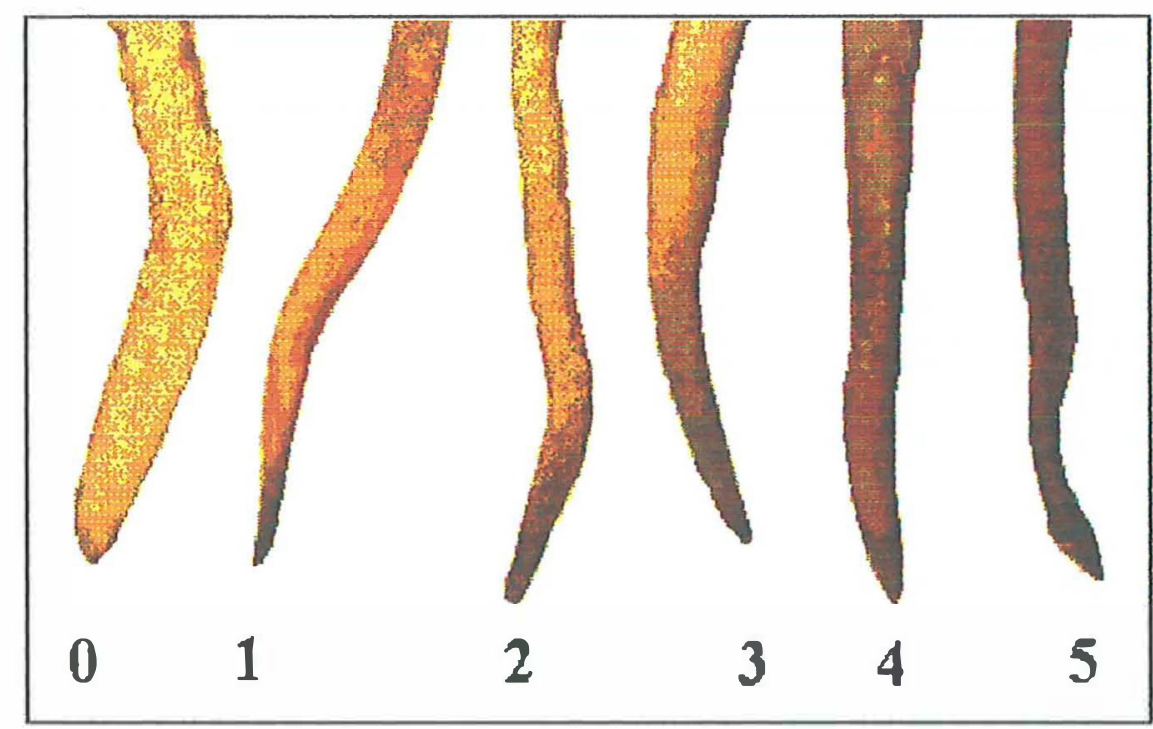

Figura 1 - Escala de notas utilizada nos experimentos com hematoxilina. 


\subsubsection{3 -Experimento 2: Otimização dos tempos de lavagem e coloração}

\subsubsection{1 -Metodologia}

Foram comparadas quatro metodologias de coloração e lavagem (Tabela 5), utilizando 20 plântulas normais de cada população expostas durante 24 horas ao alumínio. As plântulas foram crescidas em condições iguais às descritas para o experimento 1 .

Tabela 5. Técnicas de lavagem e coloração testadas.

\begin{tabular}{|c|c|c|c|c|}
\hline $\begin{array}{l}\text { Lavagem } \\
\text { (minutos) }\end{array}$ & $\begin{array}{l}\text { Coloração } \\
\text { (minutos) }\end{array}$ & $\begin{array}{c}\text { Lavagem } \\
\text { (minutos) }\end{array}$ & Condição & Referência \\
\hline 15 & 20 & 15 & Agitação horizontal suave & Cançado (1977) \\
\hline 30 & 15 & 30 & Aereação constante & Polle et al. (1978) \\
\hline 30 & 15 & 20 & Com agitação horizontal & \\
\hline 30 & 15 & 20 & Sem agitação horizontal & \\
\hline
\end{tabular}

\subsubsection{4 - Experimento final de comprovação da eficiência da técnica}

\subsubsection{1 - Material}

Neste experimento foram utilizadas 50 plântulas pertencentes a cada uma das seguintes populações: SIKALQ (original) e duas obtidas mediante a seleção em solução nutritiva, C-1 tolerante e C-1 suscetível, resultando num total de 150 plântulas avaliadas.

\subsubsection{2 - Metodologia}

\subsection{1 - Crescimento das plântulas}

As plântulas das três populações foram colocadas em câmara de crescimento, utilizando caixas de $3,5 \mathrm{l}$ de capacidade segundo um delineamento de blocos 
casualizados. As plântulas foram preparadas e submetidas ao mesmo manejo descrito no experimento 1. Antes de serem colocadas na solução nutritiva, o comprimento da raiz principal de cada plântula foi medido. A duração do experimento foi de 7 dias. No final desse período, foi medido o comprimento final das raizes e o valor do CLR para cada plântula calculado. Nesse momento a correlação entre a nota obtida na coloração de hematoxilina e o valor de CLR foi calculado.

\subsection{2- Coloração com hematoxilina}

Em função dos resultados obtidos nos experimentos preliminares, as plântulas das três populações foram avaliadas em função de uma escala de notas (Figura 1), logo após de serem submetidas a 24 horas de exposição a estresse por aluminio.

As plântulas uma vez retiradas da solução nutritiva foram lavadas durante 30 minutos com água destilada. Posteriormente, foram colocadas em um recipiente de vidro contendo a solução aquosa de hematoxilina a $2 \%$ durante 15 min. e lavadas novamente com água destilada durante $20 \mathrm{~min}$. Todas essas etapas foram realizadas submetendo as plântulas a um processo de agitação horizontal suave.

Todas as tarefas relacionadas com a eletroforese de isoenzimas e a coloração com hematoxilina foram realizadas no Laboratório de Ecologia Evolutiva e Genética Aplicada do Departamento de Genética, ESALQ-USP. 


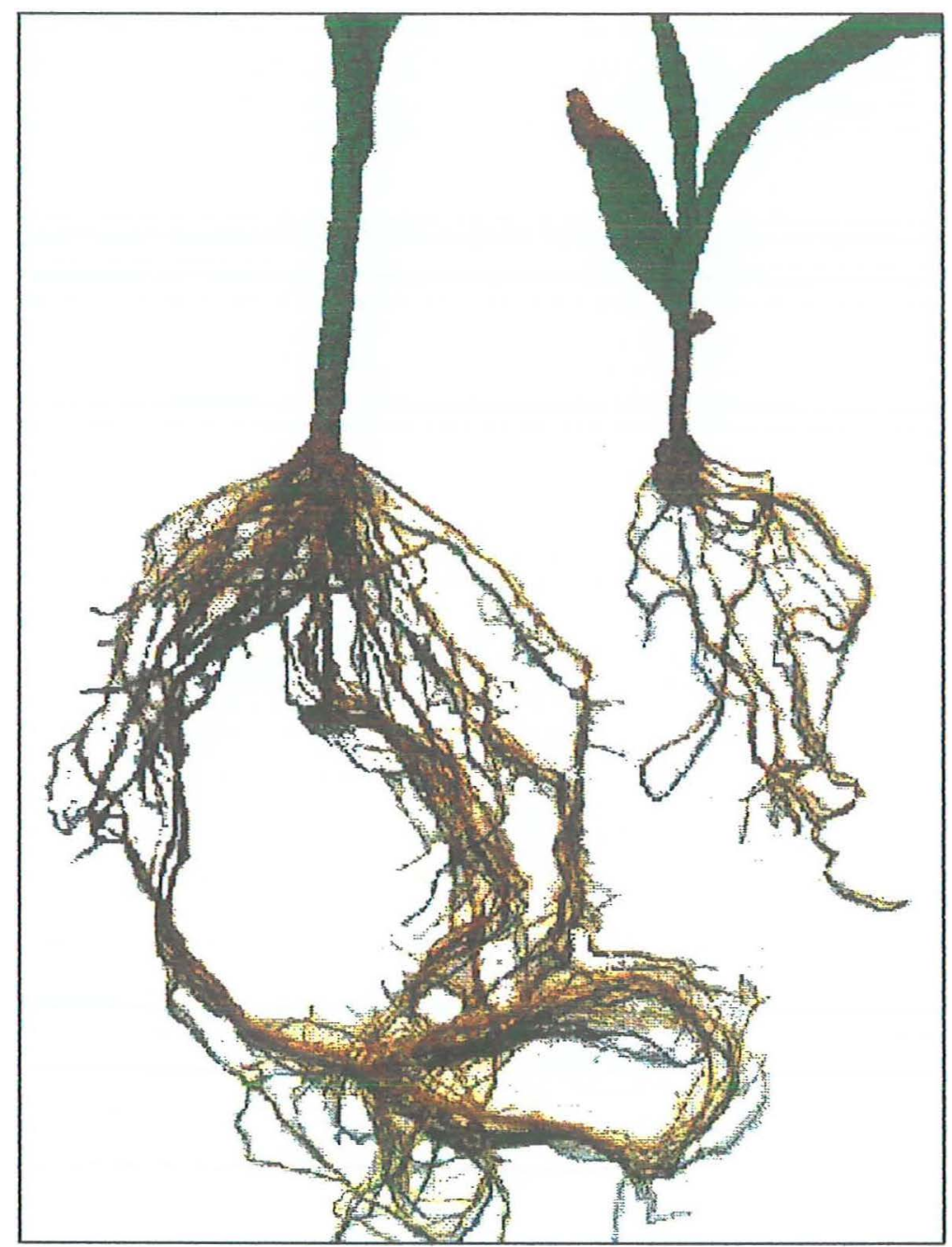

Figura 2 - Plantas selecionadas como tolerantes (esquerda) e suscetíveis (direita). 


\subsection{2 -MÉTODO 2: Estudo de variabilidade e seleção em solução nutritiva}

O caráter CLR mostrou-se muito adequado para caracterizar o comportamento tanto da população SIKALQ como das duas testemunhas em solução nutritiva (Figura 3).

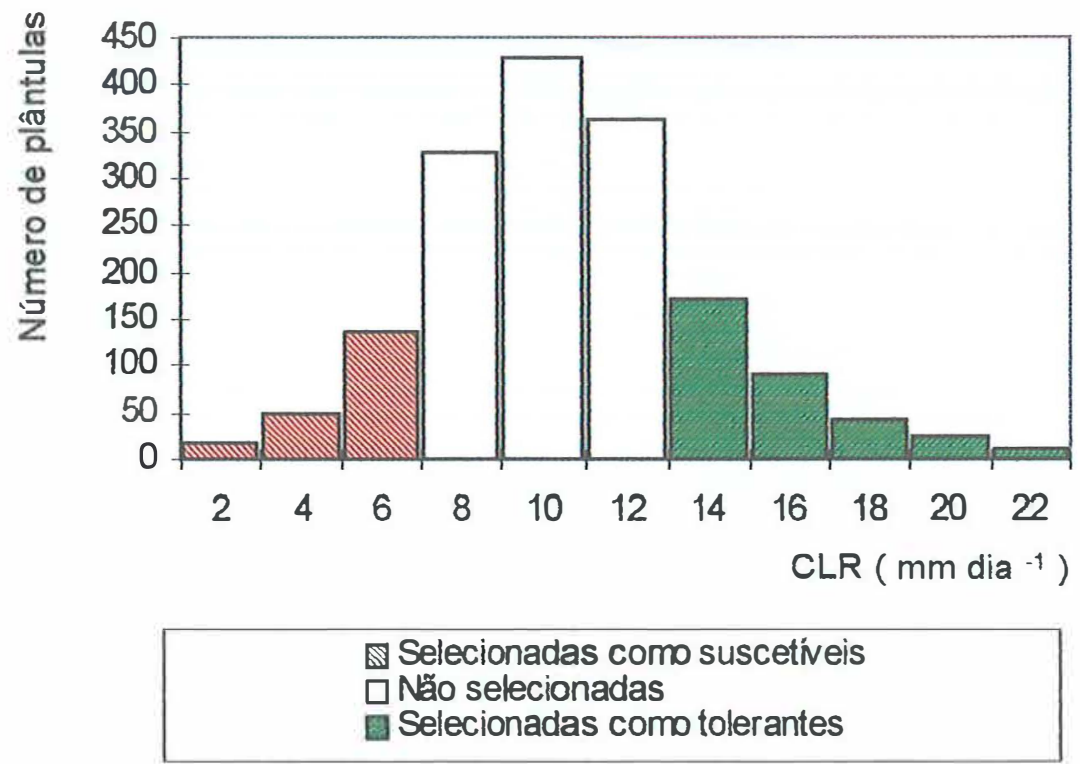

Figura 3 - Distribuição de freqüências do caráter CLR em plântulas da população SIKALQ.

Na Figura 3 está representado o crescimento da raiz principal das 1760 plantas avaliadas. Na parte direita da figura (cor verde) estão representadas as 200 plantas que apresentaram os melhores valores de crescimento e que foram selecionadas para formar a população tolerante. À esquerda da figura (cor vermelho) estão as 200 plantas que apresentaram os piores valores de CLR e que foram selecionadas para formar a população suscetível. As plântulas que apresentaram um comportamento intermediário (cor cinza) não foram selecionadas. $O$ comportamento da população foi muito 
interessante já que apresentou um número suficiente de plântulas com um comportamento sensivelmente superior e inferior às testemunhas (Tabela 6).

Na figura 4 apresentam-se, um exemplo das plantas que foram selecionadas como tolerantes e suscetíveis.

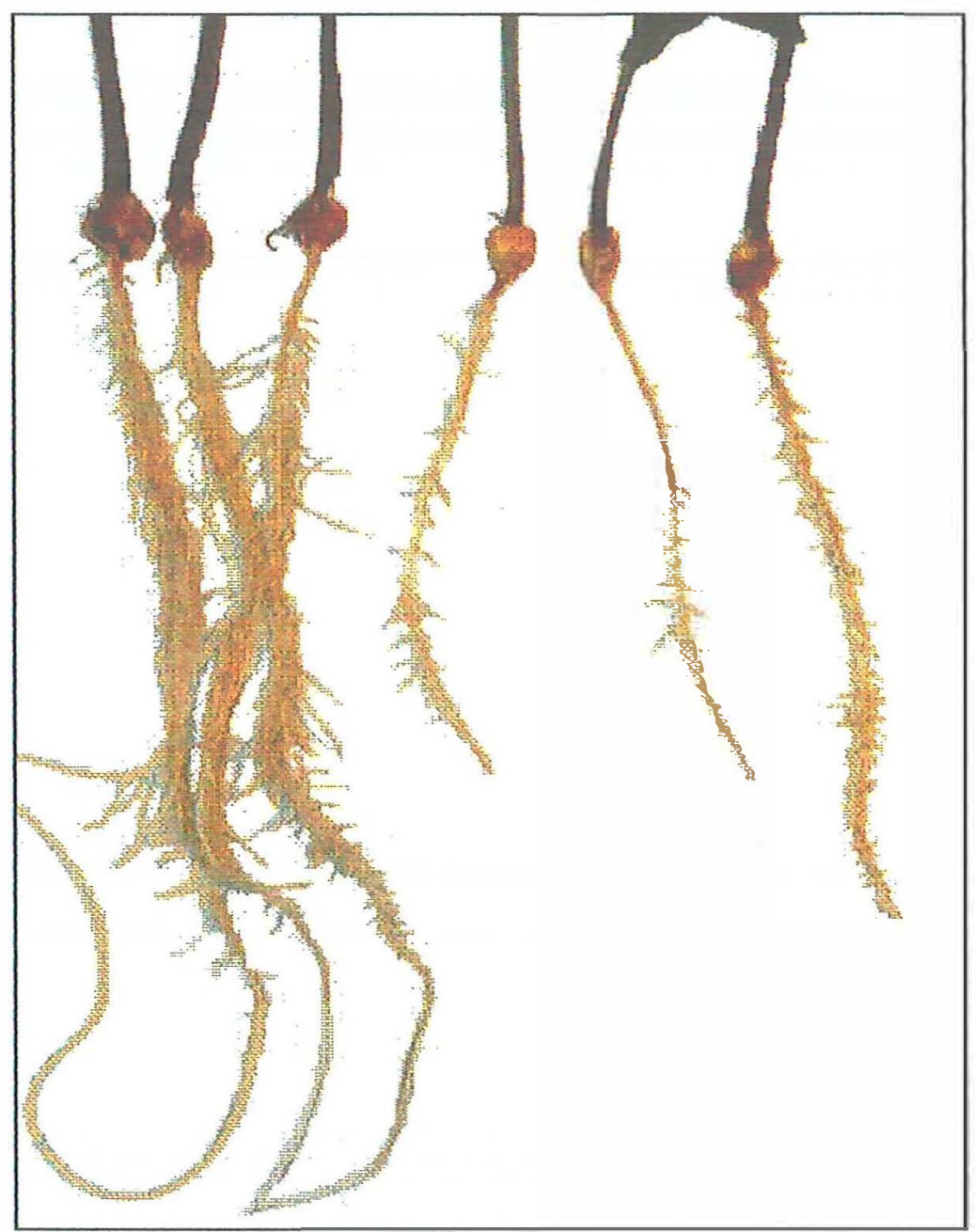

Figura 4 - Plantas selecionadas como tolerantes (esquerda) e suscetíveis (direita).

Essas diferenças estabelecidas foram confirmadas através dos valores médios de CLR de cada material (figura 5). 


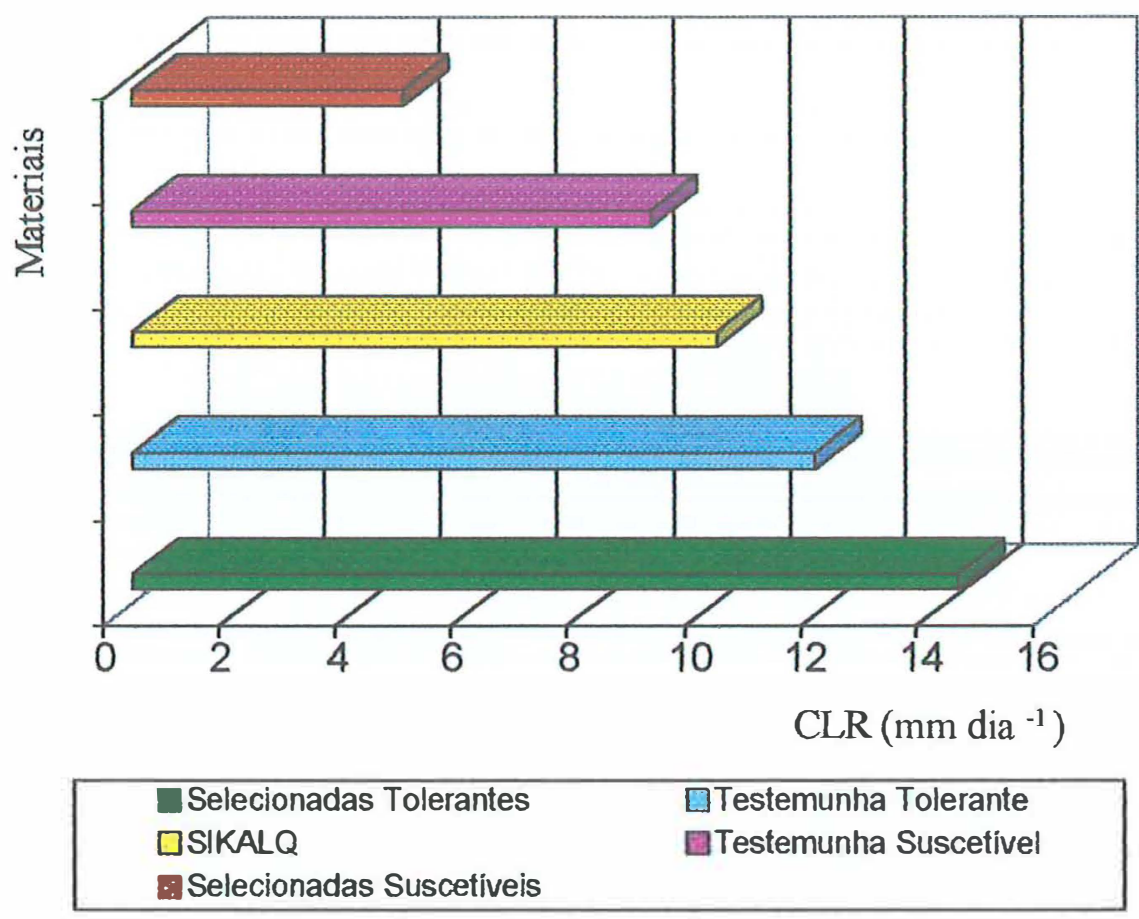

Figura 5 -Valores médios de Crescimento líquido da raiz (CLR) de cada grupo de plântulas.

Através desta figura foi possível verificar que houve grandes diferenças no comportamento das plântulas, as quais foram selecionadas para dar origem a população tolerante (PT) em relação à população original completa $(\mathrm{PO})$, às selecionadas para originar a população suscetível (PS) e as testemunhas. Na análise estatística não foram detectadas diferenças significativas, quando foi utilizada a totalidade das plantas da população SIKALQ e as testemunhas (Tabela 6 A). Embora sem diferenças significativas entre materiais, o teste de separação de médias de Duncan permitiu estabelecer diferenças no comportamento das testemunhas. Diferenças significativas foram encontradas (Tabela 6 B) quando foram utilizados unicamente os valores de CLR das plântulas selecionadas como tolerantes e suscetíveis e as testemunhas. 


\section{4- RESULTADOS E DISCUSSÃO}

\section{1 -PRIMEIRA ETAPA: Estudo de variabilidade e seleção 4.1.1 -MÉTODO 1: Estudo de variabilidade e seleção em solo álico}

Durante o processo de seleção foi possivel estabelecer diferenças importantes no desenvolvimento das plântulas, o que permitiu diferenciar os individuos tolerantes dos suscetiveis e portanto realizar um processo de seleção eficiente (Figura 2).

Foi possivel observar que as plantas consideradas como tolerantes conseguiram desenvolver mais o seu sistema radicular e alcançar a metade inferior do vaso, enquanto que as suscetiveis não conseguiram se desenvolver e ficaram limitadas unicamente à fração superior do solo.

A utilização de uma escala visual de 0 (suscetivel) a 5 (tolerante), baseada principalmente no desenvolvimento da plântula completa (raiz e parte aérea), facilitou muito o processo de seleção porque em alguns casos, plantas com bom desenvolvimento da parte radicular apresentavam problemas na parte aérea, como por exemplo sintomas de deficiência de nutrientes e de toxidez por aluminio.

Esta metodologia de seleção em vasos, apresentou como principal inconveniente o processo de lavagem das raizes com água sob pressão. Este processo exige instalações adequadas para a eliminação da água pós-lavagem e de pessoal treinado para não danificar as raizes. 
Tabela 6 - Médias dos materiais avaliados em solução nutritiva.

\begin{tabular}{|c|c|c|c|c|}
\hline Material Genético & $\begin{array}{r}\mathrm{CL} \\
(\mathrm{m}\end{array}$ & $\begin{array}{l}\text { (A) } \\
\text { ) }\end{array}$ & $\begin{array}{r}\mathbf{C L} \\
\text { (n }\end{array}$ & \\
\hline SIKALQ & 10,04 & A B & & \\
\hline Testemunha tolerante & 11,75 & A & 11,75 & B \\
\hline Testemunha suscetível & 8,91 & $\mathrm{~B}$ & 8,91 & C \\
\hline População tolerante & & & 14,19 & A \\
\hline População suscetível & & & 4,67 & $\mathrm{D}$ \\
\hline
\end{tabular}

*: **. Diferenças significativas ao 5 e $1 \%$ e ns, diferenças não significativas.

Médias seguidas pela mesma letra não diferem estatisticamente para o teste de Duncan.

O teste de Duncan detectou que houve diferenças significativas entre todos os materiais avaliados no experimento, confirmando as diferenças entre as testemunhas apontadas na discussão da Tabela $6 \mathrm{~A}$.

\subsection{SEGUNDA ETAPA: Cruzamentos no campo.}

Nesta etapa foram obtidas as quatro populações derivadas por seleção e as 100 progênies de meios irmãos.

\subsection{TERCEIRA ETAPA: Comparação das populações obtidas pelas duas metodologias de seleção.}

\subsubsection{Experimentos de campo: Análises em cada local.}

\subsubsection{Experimento em safrina - Depto. Genética, Piracicaba SP.}

No experimento realizado no campo experimental do Departamento de Genética da ESALQ-USP em Piracicaba, ficou claramente evidenciado o efeito do cruzamento introgressivo de SIKUANI V110 na população local EPB2-3A. Em geral, os caracteres 
mais afetados foram o índice de colheita, produção de grãos, porcentagem de acamamento, ciclo vegetativo e altura da planta. Já a produção de matéria seca total (MST) foi a menos afetada, embora tenha apresentado diferenças estatísticamente significativas entre os materiais.

Foi possível detectar diferenças expressivas entre os materiais avaliados referentes à produção de matéria seca total da parte aérea, porém essas diferenças não poderiam ser atribuídas ao cruzamento introgressivo ou aos processos de seleção, porque os resultados não seguiram nenhum comportamento padrão. As diferenças visuais observadas na Figura 6A podem ser comprovadas estatisticamente pelos resultados apresentados na Tabela 7 , onde foram detectadas diferenças altamente significativas entre os materiais, devido principalmente à baixa produção de matéria seca da testemunha suscetivel.

O componente da parte aérea que apresentou maior variação entre os materiais avaliados foi a produção de grãos. Essa situação poderia ser explicada com maior objetividade mediante a utilização de um parâmetro fisiológico adequado: o índice de colheita. O comportamento dos materiais em relação ao índice de colheita é apresentado na Tabela 7, onde não foi possivel verificar diferenças expressivas entre EPB2-3A com SIKALQ. Já as populações suscetíveis C-1 SSA e C-1 SSN apresentaram um comportamento bem diferente. Enquanto a primeira, nessas condições experimentais, apresentou uma alta capacidade para transformar um bom rendimento biológico em produção, a segunda obteve uma produção de MST não concordante com a produção de grãos. O alto valor apresentado pelas testemunhas de $42,9 \%$ para TT e $42,0 \%$ para TS, foram adequados para esse tipo de material porque em geral os híbridos comerciais são selecionados visando essa característica. Esses valores podem ser considerados normais desde que valores de 45 a $55 \%$ de índice de colheita são considerados como adequados para materiais de alto potencial produtivo (Andrade et al., 1996). 
Tabela 7 - Matéria seca total (MST), Índice de colheita (IC), Produção líquida (PL) e acamamento (AC) Piracicaba- Safrinha.

\begin{tabular}{|c|c|c|c|c|c|c|c|c|}
\hline Materiais & $\begin{array}{c}\text { MST } \\
\text { ( Kg ha }\end{array}$ & & $\begin{array}{l}\text { IC } \\
(\%\end{array}$ & & $\begin{array}{c}\mathbf{P L}^{\mathbf{n s}} \\
\left(\mathrm{Kg} \mathrm{ha}^{-1}\right)\end{array}$ & & $\begin{array}{c}\mathrm{AC} \text { ** } \\
(\%)\end{array}$ & \\
\hline SIKALQ & 15852,8 & $\mathrm{AB}$ & 34,3 & $A B$ & $47 \overline{85,5}$ & $A$ & 22,8 & $\bar{A}$ \\
\hline EPB2-3A & 14529,2 & $\mathrm{BC}$ & 33,3 & $A B$ & 4454,4 & A & 20,9 & A \\
\hline C-1 TSN & 14823.6 & $\mathrm{ABC}$ & 33,3 & $\mathrm{AB}$ & 4832,8 & A & 16,3 & A \\
\hline C-1 SSN & 16105,2 & $\mathrm{BC}$ & 24,5 & $\mathrm{~B}$ & 3833,7 & A & 16,6 & A \\
\hline C-1 TSA & 16487,2 & A & 32,1 & $A B$ & 5220,4 & A & 15,4 & A \\
\hline C-1 SSA & 13751,1 & $\mathrm{C}$ & 38,3 & A & 5080,8 & A & 16,5 & A \\
\hline TT & 13227,9 & $\mathrm{C}$ & 42,9 & A & 6381,3 & A & 3,2 & B \\
\hline TS & 11227,6 & $\mathrm{D}$ & 42,0 & A & 5446,6 & A & 1,3 & B \\
\hline CVe \% & 13,6 & & 14,5 & & 19,5 & & 21,0 & \\
\hline
\end{tabular}

*; **, Diferenças significativas ao 5 e $1 \%$ e ns, diferenças não significativas

Médias seguidas pela mesma letra não diferem estatisticamente para o teste de Duncan.

CVe: Coeficiente de Variação Experimental.

Outros caracteres muito afetados pela introgressão foram a produção de grãos e a porcentagem de acamamento. A relação entre a produção total de grãos e as perdas produzidas pelo acamamento estão apresentadas na Figura 6A. Nesta, cada barra representa a produção total de cada material submetido às condições ótimas de desenvolvimento. Cada barra está subdividida em duas partes. $\mathrm{Na}$ parte azul estão representadas as produções líquidas, ou seja a quantidade de grãos que realmente poderia ser colhida em condições de uma cultura extensiva e utilizando colheita mecânica. As barras vermelhas representam as perdas produzidas pelo acamamento das plantas. As excelentes condições de crescimento deste ambiente permitiram um maior desenvolvimento em altura dos materiais, aumentando a proporção de plantas que sofreram acamamento e portanto, aumentando as perdas no momento da colheita. 

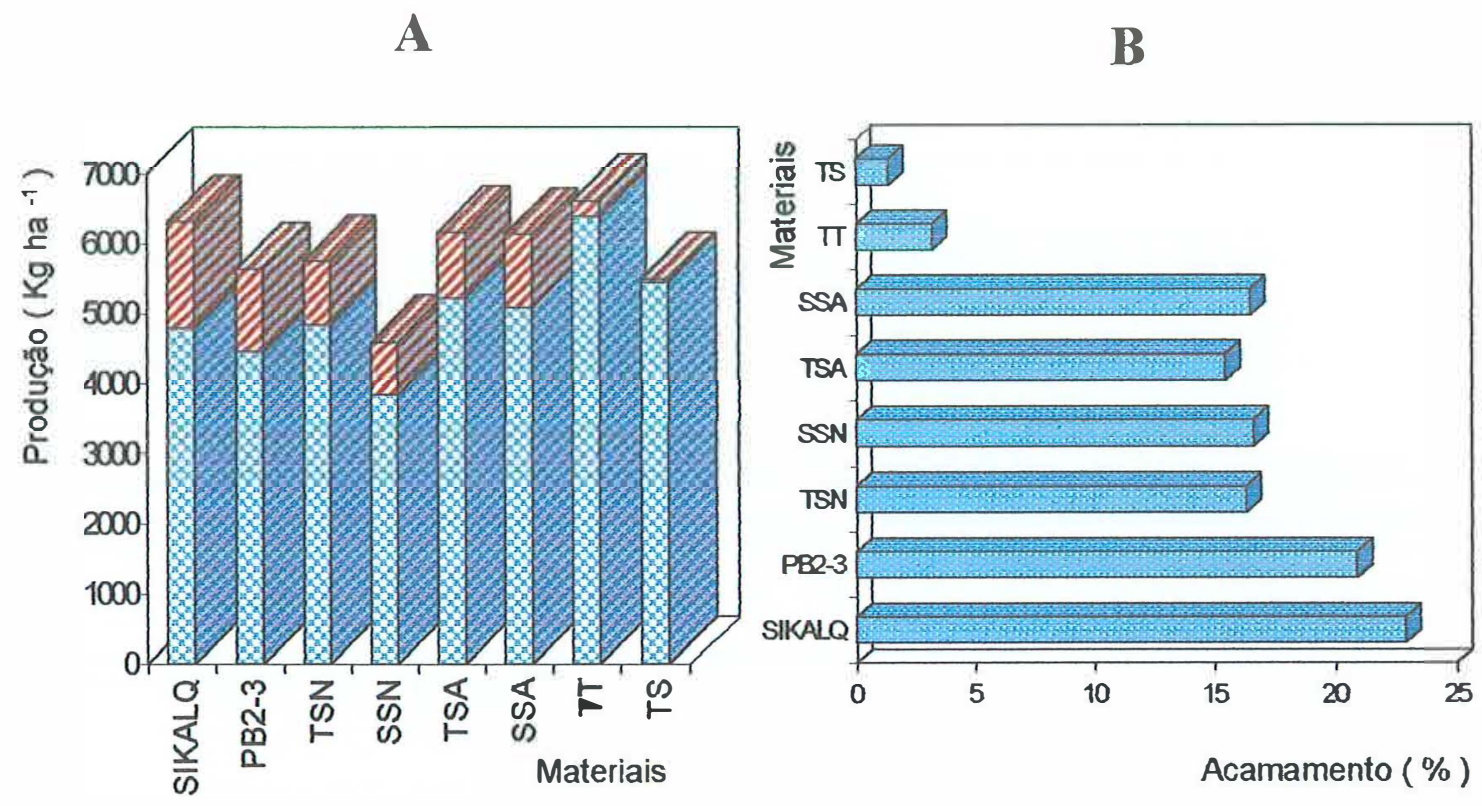

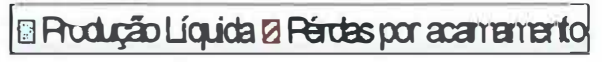

Figura 6 - Produção líquida de grãos (PL) e acamamento (AC) Piracicaba- Safrinha.

Essa situação fica melhor ilustrada com a Figura 6 B, na qual estão apresentados os valores percentuais de acamamento de cada material.

Os materiais avaliados, apresentaram um comportamento diferenciado entre eles, sendo que os dois híbridos comerciais (testemunha tolerante e suscetível respectivamente) os que apresentaram os menores valores de acamamento. Já as populações SIKALQ e EPB2-3A atingiram valores de mais de $20 \%$ de acamamento, indicando um efeito positivo para o caráter produção de grãos e outro negativo para acamamento do cruzamento introgressivo de SIKUANI V110 em EPB2-3A, evidenciando a presença desse problema na população local.

As populações selecionadas como tolerantes pelas duas metodologias (TSN e TSA) apresentaram valores de produção líquida de grãos razoáveis, produzindo mais do que EPB2-3A e SIKALQ sugerindo que a seleção para tolerância ao alumínio não 
deveria produzir quedas no potencial de rendimento das populações obtidas. Situação semelhante aconteceu com o acamamento, em que as duas populações apresentaram um comportamento intermediário entre estas e os híbridos.

O efeito da introgressão também foi observado em outros caracteres como ciclo vegetativo e altura da planta. O cruzamento introgressivo teve como resultado um aumento na altura das plantas não muito importante, porém significativo na porcentagem de acamamento observado nas duas populações e nas derivadas por seleção. Em quase todas as populações derivadas do cruzamento introgressivo, a altura das plantas resultou significativamente superior à população adaptada com exceção da população C-1 SSA que apresentou uma altura semelhante à população local.

Tabela 8 - Altura da planta (AP) e espiga (AE) e Ciclo vegetativo (CV) PiracicabaSafrinha.

\begin{tabular}{|c|c|c|c|c|c|c|}
\hline \multirow{2}{*}{$\begin{array}{l}\text { Material } \\
\text { SIKALQ }\end{array}$} & \multicolumn{2}{|c|}{$\begin{array}{l}\mathbf{A P} * * \\
(\mathrm{~cm})\end{array}$} & \multicolumn{2}{|c|}{$\begin{array}{l}\mathbf{A E} * * \\
(\mathrm{~cm})\end{array}$} & \multicolumn{2}{|c|}{$\begin{array}{c}\text { Ciclo } \mathbf{E}-\mathbf{F} \text { ** } \\
\text { (días ) }\end{array}$} \\
\hline & 210,4 & A & 111.1 & $\mathrm{BCD}$ & 52 & $\mathrm{C}$ \\
\hline EPB2-3A & 203,7 & $\mathrm{~B}$ & 109,9 & $\mathrm{CD}$ & 55 & A \\
\hline C-1 TSN & 213,8 & $\mathrm{~A}$ & 117,1 & $\mathrm{~A}$ & 52,5 & $\mathrm{BC}$ \\
\hline C-1 SSN & 214,9 & A & 116,8 & A & 52,7 & $\mathrm{BC}$ \\
\hline C-1 TSA & 212,5 & A & 113,9 & $\mathrm{ABCD}$ & 53 & B \\
\hline C-1 SSA & 199,2 & $\mathrm{~B}$ & 108,8 & $\mathrm{D}$ & 52,5 & $\mathrm{BC}$ \\
\hline TT & 211,1 & $\mathrm{~A}$ & 115,8 & A B & 52 & $\mathrm{C}$ \\
\hline TS & 210,8 & A & 114,7 & $\mathrm{ABC}$ & 53 & B \\
\hline CVe \% & \multicolumn{2}{|c|}{12,0} & \multicolumn{2}{|c|}{17,2} & & \\
\hline
\end{tabular}

*: **. Diferenças significativas ao 5 e $1 \%$ e ns, diferenças não significativas Médias seguidas pela mesma letra não diferem estatisticamente para o teste de Duncan. CVe: Coeficiente de Variação Experimental. 
Em relação à altura da espiga, todos os materiais avaliados superaram um metro de altura o que poderia explicar a alta percentagem de plantas que apresentaram acamamento. Às vezes, espigas grandes localizadas muito alto nas plantas, somado a problemas de raiz ou caule, podem ser responsáveis pelos altos índices de plantas caídas.

Outra característica influenciada pelo cruzamento introgressivo foi o ciclo vegetativo, expresso como dias entre a emergência das plântulas até 50\% de liberação do pólen. Os valores observados para o ciclo vegetativo são apresentados na Figura 8 B. Foram verificadas diferenças sensiveis na quantidade de dias necessários para atingir o momento do florescimento entre EPB2-3A e as outras populações. Essas diferenças foram confirmadas pela presença de diferenças estatísticas altamente significativas (Tabela 8) entre a população local em relação a SIKALQ e às obtidas por seleção.

A população EPB2-3A apresentou o ciclo vegetativo mais longo (55 dias) entre todos os materiais avaliados, resultando num acréscimo de dois a três dias a mais do que SIKALQ e as populações obtidas por seleção.

\subsubsection{Experimento em em safrina- Fazenda Anhembi, Anhumas SP.}

Para facilitar a análise e discussão dos resultados obtidos nos dois locais de Anhumas, os dois experimentos foram comparados simultaneamente para cada um dos caracteres avaliados.

A produção de matéria seca total (MST) dos materiais avaliados apresentou variações importantes porém não significativas (Tabela 9), tanto no experimento em solo ácido como em solo corrigido. Nos dois experimentos foi possivel observar que os materiais considerados como tolerantes produziram mais biomassa aérea do que aqueles mais sensiveis à presença de aluminio no solo. Essas diferenças ficaram mais marcantes na medida que aumentou o nivel de estresse. 
Nas duas condições de cultivo foi possível verificar o efeito do cruzamento introgressivo porque SIKALQ apresentou valores superiores de MST em relação a EPB2-3A. O processo de seleção divergente foi efetivo e em todos os casos, as populações selecionadas como tolerantes produziram mais MST do que as suscetíveis. Situação semelhante foi observada com as testemunhas, onde o hibrido tolerante superou o suscetível.

A produção de MST é um indicador relativo do comportamento de uma população quando submetida a condições de estresse. Do ponto de vista do melhoramento seria importante estabelecer quanto dessa biomassa produzida pode ser transformada em grãos. Em todos os casos os materiais considerados como tolerantes apresentaram um valor de índice de colheita superior aos suscetiveis, indicando uma maior capacidade para transformar o carbono fixado durante o processo de fotossintese em produção de grãos.

Em relação ao comportamento das populações quando comparados os índices de colheita (Tabela 9), os resultados obtidos podem ser considerados dentro dos valores esperados e não foi possivel estabelecer uma tendência de aumento ou diminuição do IC na medida que aumentava o nivel de estresse. 
Tabela 9 - Materia seca total (MST) e Índice de colheita (IC) nas duas condições de solo Anhembi - Safrinha

\begin{tabular}{|c|c|c|c|c|c|c|c|c|}
\hline \multirow{2}{*}{$\begin{array}{l}\text { Local } \\
\text { Material }\end{array}$} & \multirow{2}{*}{\multicolumn{2}{|c|}{$\begin{array}{c}\text { Solo Ácido } \\
\text { MST ** } \\
\left(\mathrm{Kg} \mathrm{ha}^{-1}\right) \\
\end{array}$}} & \multirow{2}{*}{\multicolumn{2}{|c|}{$\begin{array}{c}\text { Solo Corrigido } \\
\text { MST }^{\text {NS }} \\
\left(\mathrm{Kg} \mathrm{ha}^{-1}\right) \\
\end{array}$}} & \multirow{2}{*}{\multicolumn{2}{|c|}{$\begin{array}{l}\text { Solo Ácido } \\
\text { IC } \\
(\%)\end{array}$}} & \multirow{2}{*}{\multicolumn{2}{|c|}{$\begin{array}{c}\text { Solo Corrigido } \\
\text { IC ** } \\
(\%)\end{array}$}} \\
\hline & & & & & & & & \\
\hline SIKALQ & 7638,9 & $\mathrm{AB}$ & 9722,2 & A & 34,4 & $\mathrm{~A}$ & $38 ; 1$ & $B$ \\
\hline EPB2-3A & 6872,2 & $\mathrm{CB}$ & 9522,2 & A & 36,0 & A & 33,0 & C \\
\hline C-1 TSN & 8027,8 & A & 10638,9 & A & 39,3 & A & 39,8 & B \\
\hline C-1 SSN & 7111,1 & $\mathrm{BC}$ & 9666,7 & A & 34,9 & A & 36,5 & $\mathrm{BC}$ \\
\hline C-1 TSA & 8305,6 & A & 9083,3 & A & 39,3 & A & 40,4 & B \\
\hline C-1 SSA & 6666,7 & $\mathrm{C}$ & 9888,9 & A & 35,2 & A & 37,9 & B \\
\hline TT & 7650,0 & $A B$ & 9666,7 & A & 38,6 & A & 44,9 & A \\
\hline TS & 7305,6 & $\mathrm{BC}$ & 9250,0 & A & 37,3 & A & 38,2 & B \\
\hline CVe \% & $22, \xi$ & & 17,3 & & & & & \\
\hline
\end{tabular}

*; **, Diferenças significativas ao 5 e $1 \%$ e ns. diferenças não significativas

Médias seguidas pela mesma letra não diferem estatisticamente para o teste de Duncan.

CVe: Coeficiente de Variação Experimental.

Nos dois experimentos de Anhumas, igualmente ao acontecido em Piracicaba, foi possível detectar plantas com problemas de acamamento de raiz (Figura 7). Por isso a produção de grãos foi avaliada utilizando-se a produção líquida, que está fortemente relacionada com a porcentagem de acamamento apresentada por cada material nas duas condições de solo. 


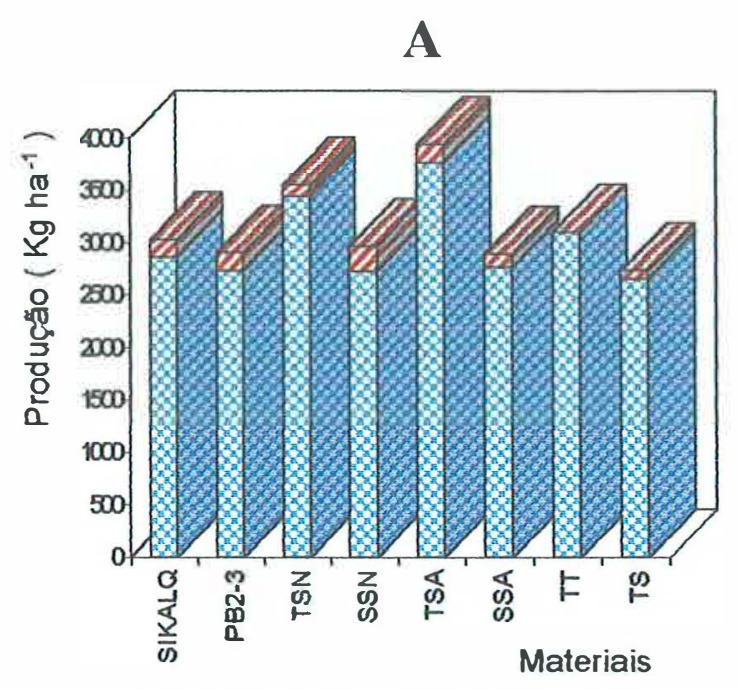

QProduçäliquidau Pérdes por acamemento

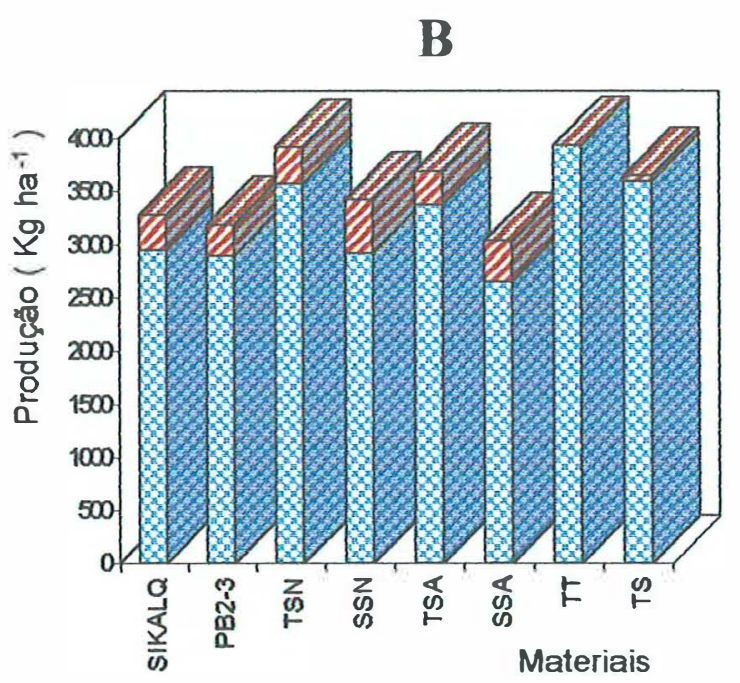

GProduçäo liquidala Pérdas por acamemento

Figura 7 - Produção líquida de grãos (PL) em solo ácido (A) e corrigido (B) Anhumas-Safrinha

Os materiais avaliados apresentaram um comportamento perfeitamente diferenciado referente à porcentagem de plantas com problemas de acamamento de raiz. Em geral a população SIKALQ apresentou os maiores valores de acamamento perdendo unicamente para as populações suscetíveis. 
Tabela 10 - Produção líquida de grãos (PL) e Acamamento (AC) nas duas condições de solo Anhembi - Safrinha.

\begin{tabular}{|c|c|c|c|c|c|c|c|c|}
\hline \multirow{3}{*}{$\begin{array}{l}\text { Local } \\
\text { Material } \\
\text { SIKALQ }\end{array}$} & \multirow{2}{*}{\multicolumn{2}{|c|}{$\begin{array}{c}\text { Solo Ácido } \\
\text { PL ** } \\
\left(\mathrm{Kg} \mathrm{ha}^{-1}\right)\end{array}$}} & \multirow{2}{*}{\multicolumn{2}{|c|}{$\begin{array}{c}\text { Solo Corrigido } \\
\text { PL * } \\
\left(\mathrm{Kg} \mathrm{ha}^{-1}\right)\end{array}$}} & \multirow{2}{*}{\multicolumn{2}{|c|}{$\begin{array}{c}\text { Solo Ácido } \\
\text { AC ** } \\
(\%) \\
\end{array}$}} & \multirow{2}{*}{\multicolumn{2}{|c|}{$\begin{array}{c}\text { Solo Corrigido } \\
\mathrm{AC} * * \\
(\%)\end{array}$}} \\
\hline & & & & & & & & \\
\hline & 2860,5 & $\mathrm{BC}$ & 2974,7 & $\mathrm{BC}$ & 5,8 & $A B$ & $10 ; 5$ & $\mathrm{AB}$ \\
\hline EPB2-3A & 2730,4 & $\mathrm{C}$ & 2890,6 & $\mathrm{BC}$ & 4,9 & $\mathrm{AB}$ & 9,1 & $\mathrm{AB}$ \\
\hline C-1 TSN & 3441,4 & $\mathrm{AB}$ & 3573,1 & $\mathrm{ABC}$ & 3,0 & $\mathrm{BC}$ & 8,9 & $\mathrm{AB}$ \\
\hline C-1 SSN & 2721,1 & $\mathrm{C}$ & 2922,8 & $\mathrm{BC}$ & 8,3 & A & 14,2 & A \\
\hline C-1 TSA & 3764,3 & A & 3380,2 & $\mathrm{ABC}$ & 4,4 & $\mathrm{ABC}$ & 7,9 & B \\
\hline C-1 SSA & 2764,9 & $\mathrm{C}$ & 2649,6 & $\mathrm{C}$ & 5,7 & $\mathrm{AB}$ & 12,7 & $\mathrm{AB}$ \\
\hline TT & 3100,2 & $\mathrm{BC}$ & 3937,5 & A & 3,2 & $\mathrm{BC}$ & 1,6 & $\mathrm{C}$ \\
\hline TS & 2651,4 & $\mathrm{C}$ & 3598,9 & $\mathrm{AB}$ & 0,00 & $\mathrm{C}$ & 0,00 & $\mathrm{C}$ \\
\hline CVe \% & \multicolumn{2}{|c|}{13,84} & \multicolumn{2}{|c|}{17,51} & \multicolumn{2}{|c|}{26,84} & \multicolumn{2}{|c|}{20.40} \\
\hline
\end{tabular}

Os menores valores de acamamento, igual ao acontecido no experimento de Piracicaba, foram os apresentados pelas testemunhas. Essa situação era esperada porque são híbridos comerciais selecionados para esse caráter.

Confirmando o apontado para o caráter MST, a PL dos materiais considerados tolerantes foi sempre superior à apresentada pelos suscetíveis (Figura 7, Tabela 10) confirmando a efetividade do processo de seleção divergente. Assim no experimento em solo ácido (Figura $7 \mathrm{~A}$, Tabela 10) houve um pequeno aumento na $\mathrm{PL}$ devido à introgressão de $130 \mathrm{~kg} \mathrm{ha}^{-1}$, o que representa um aumento de 4,76\%. Já as populações selecionadas para tolerância apresentaram um comportamento sensivelmente superior às originais e às suscetiveis. O melhor valor de produção líquida foi obtido pela população selecionada em solo álico (C-1 TSA) que apresentou um aumento de $322,9 \mathrm{~kg} \mathrm{ha}^{-1}$ 
$(9,38 \%)$ em relação à outra população tolerante (C-1 TSN). As diferenças foram maiores quando foi comparado o comportamento de C-1 TSA com as populações originais e a suscetivel. Assim C-1 TSA apresentou um aumento na produção líquida de 1033,9 kg $\mathrm{ha}^{-1}$, de $903,9 \mathrm{~kg} \mathrm{ha}^{-1}$ e de $999,4 \mathrm{~kg} \mathrm{ha}^{-1}$ em relação a EPB2-3A, SIKALQ e à população suscetivel C-1 SSA.

A outra população tolerante, selecionada utilizando solução nutritiva (C-1 TSN), obteve um comportamento muito bom, apresentando um aumento na PL de 126,04 kg $\mathrm{ha}^{-1}$, de $120,31 \mathrm{~kg} \mathrm{ha}^{-1} \mathrm{e} \cdot \mathrm{de} 126,47 \cdot \mathrm{kg} \mathrm{ha}^{-1}$ em relação a EPB2-3A, SIKALQ $\cdot$ e a população suscetivel C-1 SSN. As testemunhas apresentaram um comportamento perfeitamente diferenciado e a testemunha tolerante teve um aumento na PL de $448 \mathrm{~kg}$ $\mathrm{ha}^{-1}$ em-relação à suscetível.

No experimento em solo corrigido, ao contrário do esperado, não foram observados aumentos importantes no rendimento dos materiais avaliados, em relação ao experimento sem correção de solo, o que permite supor que a menor disponibilidade hidrica e principalmente as baixas temperaturas limitaram mais o rendimento do milho do que as condições nutricionais. Isto poderia explicar a baixa resposta ao agregado de nutrientes essenciais como nitrogênio, fósforo, cálcio e potássio.

Mesmo com essa menor resposta às melhores condições nutricionais, foi possível verificar que em todos os casos, os materiais tolerantes apresentaram uma PL superior aqueles considerados suscetiveis. Por exemplo, a testemunha tolerante apresentou um aumento na PL de $338,6 \mathrm{~kg} \mathrm{ha}^{-1}$ em relação à testemunha suscetível. Na condição de solo corrigido, igual ao acontecido em solo ácido, foi possivel estabelecer o efeito do cruzamento introgressivo, porque SIKALQ apresentou um aumento da PL de 84,1 kg $\mathrm{ha}^{-1}$ em rẹlação à EPB2-3A.

A população C-1 TSN apresentou o melhor comportamento entre as populações com um aumento na PL de 192,9 $\mathrm{kg} \mathrm{ha}^{-1}$, de 682,5 $\mathrm{kg} \mathrm{ha}^{-1}$, de 598,4 $\mathrm{kg} \mathrm{ha}^{-1}$ e de 650,3 $\mathrm{kg} \mathrm{ha}^{-1}$ em relação a C-1 TSA, EPB2-3A, SIKALQ e a população suscetível C-1 SSN, respectivamente. A outra população tolerante (C-1 TSA) apresentou um comportamento muito bom, com um aumento na PL de $489 \mathrm{~kg} \mathrm{ha}^{-1}$, de 405,5 $\mathrm{kg} \mathrm{ha}^{-1}$ e de 730,6 $\mathrm{kg} \mathrm{ha}^{-1}$ 
quando comparado com EPB2-3A, SIKALQ e a população suscetivel C-1 SSA respectivamente.

Outro caráter que apresentou uma relação estreita com a tolerância foi a altura da planta (AP). Para este caráter verificou-se que os materiais considerados tolerantes apresentaram nas duas condições de solo utilizadas uma altura maior do que os suscetiveis. Diferenças estatisticamente significativas para AP foram encontradas apenas no experimento em solo corrigido. Já no outro experimento, as condições ambientais fizeram com que as plantas apresentassem uma sensível queda na altura. Mesmo com essa diminuição generalizada na AP, observou-se que os materiais tolerantes apresentaram uma tendência a ser mais altos do que os suscetíveis (Tabela 11).

Tabela 11- Altura de planta (AP) e espiga (AE) nas duas condições de solo Anhembi Safrinha.

\begin{tabular}{|c|c|c|c|c|c|c|c|c|}
\hline \multirow{3}{*}{$\begin{array}{l}\text { Local } \\
\text { Material } \\
\text { SIKALQ }\end{array}$} & \multirow{2}{*}{\multicolumn{2}{|c|}{$\begin{array}{c}\text { Solo Ácido } \\
\text { AP }^{\text {NS }} \\
(\mathrm{cm})\end{array}$}} & \multirow{2}{*}{\multicolumn{2}{|c|}{$\begin{array}{c}\text { Solo Corrigido } \\
\mathbf{A P} * \star \\
(\mathrm{cm}) \\
\end{array}$}} & \multirow{2}{*}{\multicolumn{2}{|c|}{$\begin{array}{c}\text { Solo Ácido } \\
\text { AE * * } \\
(\mathrm{cm})\end{array}$}} & \multirow{2}{*}{\multicolumn{2}{|c|}{$\begin{array}{c}\text { Solo Corrigido } \\
\mathbf{A E} * * \\
(\mathrm{~cm}) \\
\end{array}$}} \\
\hline & & & & & & & & \\
\hline & 137,8 & $\mathrm{~A}$ & 157,0 & $\mathrm{~A}$ & 57,3 & $\mathrm{BC}$ & 75,7 & $\overline{A B}$ \\
\hline EPB2-3A & 133,4 & A & 154,7 & $\mathrm{AB}$ & 58,5 & $\mathrm{AB}$ & 73,8 & $\mathrm{AB}$ \\
\hline C-1 TSN & 136,0 & A & 153,9 & $\mathrm{ABC}$ & 54,7 & $\mathrm{C}$ & 72,1 & $\mathrm{BC}$ \\
\hline C-1 SSN & 133,6 & $\mathrm{~A}$ & 149,4 & $\mathrm{C}$ & 56,6 & $\mathrm{BC}$ & 73,3 & $\mathrm{AB}$ \\
\hline C-1 TSA & 141,9 & A & 155,5 & $A B$ & 61,9 & A & 75,9 & A \\
\hline C-1 SSA & 136,7 & A & 150,7 & $\mathrm{BC}$ & 58,5 & $A B$ & 72,9 & B \\
\hline TT & 140,8 & A & 152,1 & $\mathrm{ABC}$ & 46,6 & $\mathrm{E}$ & 63,8 & $\mathrm{D}$ \\
\hline TS & 127,1 & A & 144,6 & $\mathrm{D}$ & 50,3 & $\mathrm{D}$ & 69,2 & \\
\hline CVe \% & \multicolumn{2}{|c|}{21,89} & \multicolumn{2}{|c|}{19,64} & \multicolumn{2}{|c|}{19,71} & \multicolumn{2}{|c|}{18,01} \\
\hline
\end{tabular}

*: **, Diferenças significativas ao 5 e $1 \%$ e ns, diferenças não significativas Médias seguidas pela mesma letra não diferem estatisticamente para o teste de Duncan. CVe: Coeficiente de Variação Experimental. 
O caráter altura da espiga (AE) apresentou nas duas condições de solo, diferenças estatísticas altamente significativas entre os materiais avaliados. Os menores valores de altura da espiga, característica importante para a colheita mecânica e perigo de acamamento, foram apresentados pelas testemunhas. Estos resultados também eram esperados uma vez que esses materiais foram selecionados para essa característica.

O caráter ciclo vegetativo $(\mathrm{CV})$, apresentou um comportamento semelhante ao relatado para outros caracteres como PL e AP. Em todos os casos houve um aumento sensivel na quantidade de dias requeridos para atingir o florescimento em relação ao experimento de Piracicaba. Por exemplo, a população EPB2-3A que apresentou um CV de 55 dias em Piracicaba, não sofreu alterações no experimento em solo corrigido e foi fortemente influenciada pelas condições nutricionais menos favoráveis do experimento em solo ácido, aumentando o CV para 62 dias.

Nos dois experimentos de Anhumas foram detectadas diferenças estatisticamente significativas para o caráter $\mathrm{CV}$, evidenciando que os materiais sensiveis ao alumínio sofreram proporcionalmente muito mais o estresse produzido pelo ambiente menos favorável, aumentando sensivelmente o $\mathrm{CV}$ quando submetidos às piores condições nutricionais presentes no experimento com solo ácido.

As diferenças no $\mathrm{CV}$ observadas entre os dois experimentos de Anhumas podem ser atribuídas às diferenças nutricionais existentes entre os experimentos. Como os experimentos foram plantados no mesmo dia, fatores ambientais que afetam o ciclo vegetativo como fotoperiodo e temperatura foram descartados. Embora não existam evidências de que o aumento do teor de alumínio possa afetar o $\mathrm{CV}$ do milho, os outros nutrientes que estavam em déficit como o nitrogênio e fósforo apresentaram um efeito já comprovado sobre a duração do ciclo vegetativo.

Para o nitrogênio, foram reportados atrasos de 8 até 11 dias no ciclo vegetativo em plantas de milho submetidas ao estresse por déficit do nutriente (Jacobs \& Pearson, 1991 ; Uhart \& Andrade, 1995). 
O efeito do fósforo no desenvolvimento do milho tem sido menos estudado do que o nitrogênio. Assim, Spence \& Welch $^{1}$, citados por Andrade et al (1996) reportaram uma aumento no $\mathrm{CV}$ na medida que diminuía a disponibilidade de fósforo.

Tabela 12 - Ciclo vegetativo (CV) nas duas condições de solo Anhembi - Safrinha.

\begin{tabular}{|c|c|c|c|c|}
\hline Local & \multicolumn{2}{|c|}{ Solo Ácido } & \multicolumn{2}{|c|}{ Solo Corrigido } \\
\hline Material & \multicolumn{2}{|c|}{$\begin{array}{l}\mathbf{C V} * * \\
\text { (dias) }\end{array}$} & \multicolumn{2}{|c|}{$\begin{array}{l}\mathbf{C V} * * \\
\text { (dias) }\end{array}$} \\
\hline SIKALQ & 58,0 & $E$ & 53,5 & $\mathrm{C}$ \\
\hline EPB2-3A & 62,0 & A & 55,5 & A \\
\hline C-1 TSN & 58,0 & $\mathrm{E}$ & 53,0 & $\mathrm{D}$ \\
\hline C-1 SSN & 58,5 & D & 54,0 & $\mathrm{C}$ \\
\hline C-1 TSA & 58,5 & $\mathrm{D}$ & 54,5 & B \\
\hline C-1 SSA & 59,0 & $\mathrm{C}$ & 54,0 & $\mathrm{C}$ \\
\hline TT & 58,0 & $\mathrm{E}$ & 53,5 & C \\
\hline TS & 60,0 & B & 54,0 & C \\
\hline $\mathrm{CVe} \%$ & \multicolumn{2}{|c|}{0,45} & \multicolumn{2}{|c|}{0,54} \\
\hline
\end{tabular}

*:**, Diferenças significativas ao 5 e $1 \%$ e ns. diferenças não significativas

Médias seguidas pela mesma letra não diferem estatisticamente para o teste de Duncan.

CVe: Coeficiente de Variação Experimental.

\footnotetext{
' SPENCE. C.O.: WELCH. C.D. Phosphorous fertilization for grain sorghum production in the Texas blackland. Texas University. Leaflet L-1550.
} 


\subsubsection{Experimento em safrina - Pindamonhangaba SP, Fazenda IAC.}

A maior disponibilidade de alumínio trocável presente no solo utilizado na fazenda do IAC em Pindamonhangaba SP, fez com que as diferenças observadas entre os materiais no experimento em solo ácido de Anhumas ficassem ainda mais evidentes. Em geral houve uma queda acentuada na produção de grãos, embora os materiais tolerantes tenham-se comportado muito melhor do que os suscetíveis (Figura 8, Tabela 13). O efeito da introgressão de SIKUANI ficou evidenciado pelo aumento de rendimento de SIKALQ em relação a PB2-3A de 9,42\%. As duas metodologias de seleção utilizadas permitiram obter aumento de rendimentos em relação a SIKALQ e foi comprovada a eficiência do processo de seleção divergente realizado. Tanto C-1TSN como C-1TSA apresentaram um aumento na produção em relação a SIKALQ de 9,27\% e 14,59\%, respectivamente. Foram observadas diferenças importantes entre as populações tolerantes e suscetíveis obtidas pelas duas metodologias, sendo assim, as populações selecionadas em solução nutritiva apresentaram uma diferença de rendimento de $19,63 \%$ enquanto que nas selecionadas em solo álico a diferença foi mais evidente, atingindo o valor de $38,53 \%$.

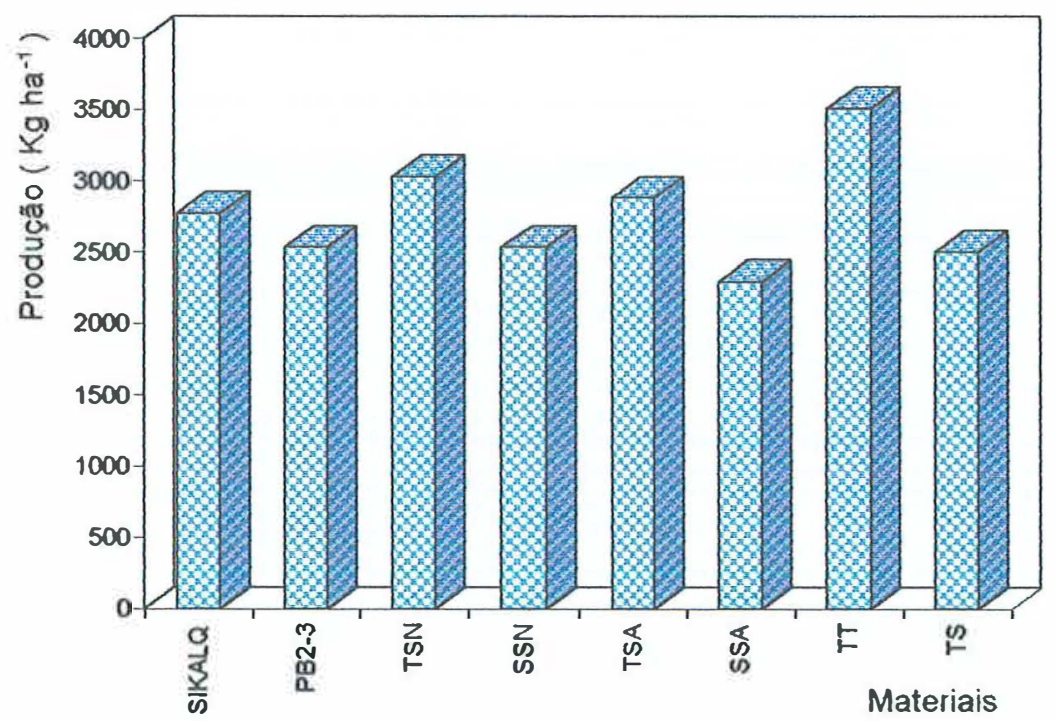

Figura 8 - Produção líquida de grãos (PL) dos materiais avaliados Pindamonhangaba Safrinha. 
O caráter altura da planta foi afetado fortemente pelas condições ambientais deste local, onde foram observadas diferenças estatisticamente significativas entre as populações.

Uma diminuição importante na altura de todos os materiais avaliados como resultado de um maior teor de alumínio e de temperaturas mais baixas foi observada, porém, foi possivel comprovar a tendência apresentada nos experimentos de Anhumas onde na medida em que aumentava o teor de alumínio, os materiais considerados tolerantes apresentaram uma altura maior do que os suscetíveis (Tabela 13).

Tabela 13 - Produção líquida (PL), Altura da planta (AP) e espiga (AE) e acamamento (AC) Pindamonhangaba - Safrinha.

\begin{tabular}{|c|c|c|c|c|c|c|c|c|}
\hline \multirow{2}{*}{$\begin{array}{l}\text { Material } \\
\text { SIKALQ }\end{array}$} & \multicolumn{2}{|c|}{$\begin{array}{c}\mathbf{P L} * \\
\left(\mathrm{Kg} \mathrm{ha}^{-1}\right)\end{array}$} & \multicolumn{2}{|c|}{$\begin{array}{l}\mathbf{A P * *} \\
(\mathrm{cm})\end{array}$} & \multicolumn{2}{|c|}{$\begin{array}{l}\mathbf{A E} * * \\
(\mathrm{~cm})\end{array}$} & \multicolumn{2}{|c|}{$\begin{array}{l}\mathbf{C V * *} \\
(\text { días })\end{array}$} \\
\hline & 2773,5 & $\mathrm{ABC}$ & 124,55 & $\bar{A}$ & 44,40 & $\overline{\mathrm{AB}}$ & 71 & $\mathrm{C}$ \\
\hline EPB2-3A & 2534,7 & $\mathrm{BC}$ & 112,45 & $\mathrm{CD}$ & 39,60 & $\mathrm{BC}$ & 77 & A \\
\hline C-1 TSN & 3030,8 & $\mathrm{ABC}$ & 122,45 & A & 45,40 & A & 71 & $\mathrm{C}$ \\
\hline C-1 SSN & 2533,4 & $\mathrm{BC}$ & 112,95 & $\mathrm{CD}$ & 38,65 & $\mathrm{C}$ & 73 & $\mathrm{~B}$ \\
\hline C-1 TSA & 3178,2 & $\mathrm{AB}$ & 120,60 & $\mathrm{AB}$ & 46,85 & A & 72 & $\mathrm{BC}$ \\
\hline C-1 SSA & 2294,2 & $\mathrm{C}$ & 104,40 & $\mathrm{E}$ & 35,00 & $\mathrm{C}$ & 73 & B \\
\hline TT & 3505,5 & A & 114,74 & $\mathrm{BC}$ & 39,10 & $\mathrm{BC}$ & 71 & $\mathrm{C}$ \\
\hline TS & 2503,5 & $\mathrm{BC}$ & 106,50 & $\mathrm{DE}$ & 35,65 & $\mathrm{C}$ & 73 & B \\
\hline CVe \% & \multicolumn{2}{|c|}{20,20} & \multicolumn{2}{|c|}{9,36} & \multicolumn{2}{|c|}{20,61} & \multicolumn{2}{|c|}{0,93} \\
\hline
\end{tabular}

*; **, Diferenças significativas ao 5 e $1 \%$ e ns, diferenças não significativas Médias seguidas pela mesma letra não diferem estatisticamente para o teste de Duncan. CVe: Coeficiente de Variação Experimental.

Devido ao fato de que o caráter altura da espiga está ligado diretamente com a altura da planta, também foi fortemente afetado pelas condições ambientais, apresentando 
diferenças estatisticamente significativas, porém sem seguir um comportamento padrão bem definido.

Outro caráter bastante afetado pelas condições ambientais do local de Pindamonhangaba foi o CV. Os materiais avaliados apresentaram diferenças estatísticas significativas (Tabela 13) e em todos os casos, aconteceu um alongamento do CV devido ao ambiente.

Em geral, houve um atraso maior na data de liberação de pólen nos materiais mais sensiveis ao alumínio. Estes resultados estão em concordância com os reportados para os experimentos de Anhumas.

\subsubsection{Experimento em época normal - Depto. Genética, Piracicaba SP.}

Tal como esperado, as melhores condições climáticas existentes na época normal de plantío apresentaram um efeito marcante na maioria dos caracteres avaliados. $\mathrm{O}$ caráter MST apresentou um aumento muito expressivo em relação à safrinha.

Contrario do observado em safrinha, não foi possivel verificar o efeito do cruzamento introgressivo porque SIKALQ apresentou uma produção de MST um pouco inferior à apresentada por EPB2-3A. As testemunhas mantiveram o mesmo padrão de comportamento e TT apresentou uma produção de biomassa aérea superior a TS. Embora a altura da planta (Tabela 14) em geral tenha sido um pouco menor do que na. safrinha, a presença de plantas mais robustas, um tamanho maior de espigas e portanto uma maior produção de grão, seriam os responsáveis pelo aumento na produção de MST, o que pode ser comprovado através do aumento do IC observado em todos os materiais. Os dois híbridos, utilizados como testemunhas, apresetaram os melhores valores de IC, tal como seria esperado num ambiente de alta produtividade. A população C-1 SSA apresentou um IC alto como resultado de uma produção relativamente baixa de MST combinado com uma boa produção de grãos. 
Tabela 14 - Matéria seca total (MST), Índice de colheita (IC), Produção líquida (PL) e acamamento (AC) Piracicaba- Época normal.

\begin{tabular}{|c|c|c|c|c|c|c|c|c|}
\hline \multirow{2}{*}{$\begin{array}{l}\text { Materiais } \\
\text { SIKALQ }\end{array}$} & \multicolumn{2}{|c|}{$\begin{array}{c}\text { MST } \\
\left(\mathrm{Kg} \mathrm{ha}^{\mathrm{NS}}\right)\end{array}$} & \multicolumn{2}{|c|}{$\begin{array}{l}\mathrm{IC} \mathrm{C}^{* *} \\
(\%)\end{array}$} & \multicolumn{2}{|c|}{$\begin{array}{c}\text { PL }^{\mathrm{NS}} \\
\left(\mathrm{Kg} \mathrm{ha}^{-1}\right)\end{array}$} & \multicolumn{2}{|c|}{$\begin{array}{c}\mathbf{A C} * * \\
(\%)\end{array}$} \\
\hline & 23250,0 & A & 34,58 & D & 6532,6 & $\mathrm{~B}$ & 9,7 & A \\
\hline EPB2-3A & 23889,9 & A & 38,75 & $\mathrm{CD}$ & 6832,0 & $\mathrm{AB}$ & 6,4 & $\mathrm{ABC}$ \\
\hline C-1 TSN & 21472,2 & A & 44,59 & $\mathrm{AB}$ & 7412,4 & $\mathrm{AB}$ & 2,4 & $\mathrm{BC}$ \\
\hline C-1 SSN & 23350,6 & A & 41,46 & $\mathrm{BC}$ & 7033,6 & $\mathrm{AB}$ & 9,2 & A \\
\hline C-1 TSA & 23194,4 & A & 38,56 & CD & 6515,4 & B & 9,1 & A \\
\hline C-1 SSA & 22250,0 & A & 45,43 & $\mathrm{AB}$ & 7498,8 & $\mathrm{AB}$ & 7,4 & $\mathrm{AB}$ \\
\hline TT & 23472,2 & A & 46,95 & A & 8814,8 & A & 0,0 & $\mathrm{C}$ \\
\hline TS & 23128,8 & A & 45,14 & $\mathrm{AB}$ & 8201,8 & $\mathrm{AB}$ & 1,9 & $\mathrm{BC}$ \\
\hline CVe \% & \multicolumn{2}{|c|}{6,50} & \multicolumn{2}{|c|}{5,92} & \multicolumn{2}{|c|}{17,58} & \multicolumn{2}{|c|}{71,34} \\
\hline
\end{tabular}

*:**, Diferenças significativas ao 5 e $1 \%$ e ns, diferenças não significativas

Médias seguidas pela mesma letra não diferem estatisticamente para o teste de Duncan.

CVe: Coeficiente de Variação Experimental.

A produção de grãos, em especial a produção líquida (PL) (Figura 9 A) foi afetada favoravelmente pelas condições ambientais da época normal de plantio. As altas temperaturas, radiação incidente e a boa disponibilidade de água e nutrientes fizeram com que os materiais apresentassem um alto potencial de rendimento. A média geral do experimento foi $30 \%$ superior ao observado no experimento de safrinha. Esta situação pode ser explicada analisando dois fatores: $O$ primeiro é o marcante aumento na produção total de grãos como resultado de um maior número e peso dos grãos. Essas diferenças entre épocas de plantio contrastantes foi reportado por outros autores que estabeleceram que, o deslocamento da data de plantío para condições de menor radiação incidente e a temperatura afetam fortemente os rendimentos da cultura de milho (Duncan et al., 1973; Tollenaar et al.,1992). Assim foram reportados tanto uma sensível redução na quantidade de grãos estabelecidos por espiga (Cirilo \&Andrade, 1994), como 
no número de espigas por planta (Andrade et al., 1996) na medida em que o plantio foi deslocado para condições de baixa temperatura e radiação.

O segundo fator que permite explicar o aumento na PL foi a importante redução na porcentagem de acamamento .

Igualmente ao observado em safrinha, os híbridos comerciais utilizados como testemunhas apresentaram os melhores valores de produção, assim como, foi possível confirmar o alto potencial de rendimento das populações selecionadas.
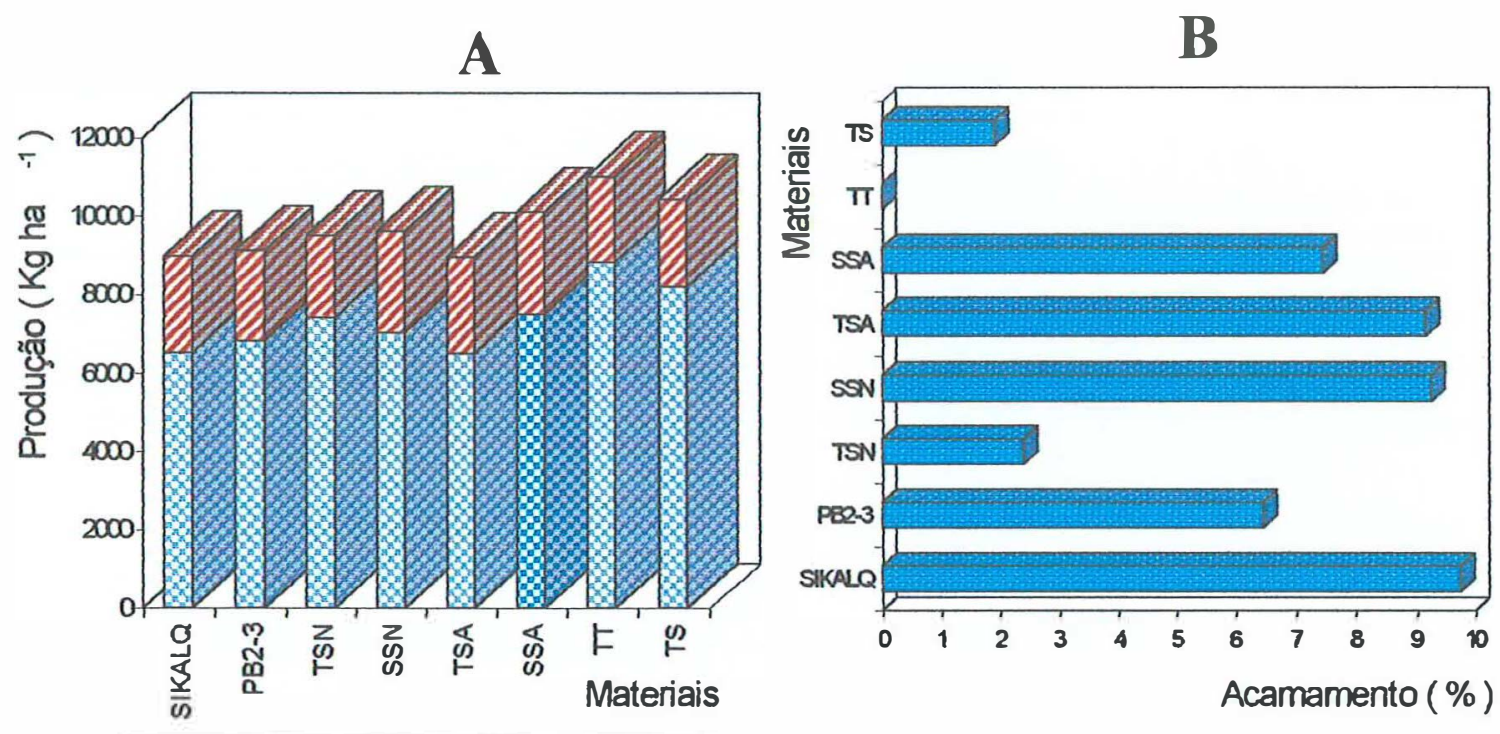

SToduçăo Liquida V Péndas por acamerreto

Figura 9 - Produção líquida de grãos (PL) e acamamento (AC) Piracicaba- Época normal.

Os materiais avaliados apresentaram um comportamento perfeitamente diferenciado em relação ao AC (Figura 9B). Foi observado que as diferentes condições ambientais, embora responsáveis por uma maior produção de grãos, permitiram uma redução do acamamento de $60 \%$ em relação ao observado em safrinha. Esta redução pode ser explicada numa modificação da relação fonte-dreno nos materiais 
avaliados que permitiu uma menor altura da planta e espiga e um melhor desenvolvimento de raízes. Os híbridos comerciais apresentaram os menores valores de acamamento enquanto que o comportamento de SIKALQ permitiu confirmar a presença do problema nessa população apontado em safrinha.

Contrariamente ao esperado, a altura da planta foi moderadamente inferior aos valores observados em safrinha. Essas diferenças podem ser atribuídas ao fato de que a etapa vegetativa do experimento de safrinha coincidiu com um período de temperaturas relativamente altas, o que permitiu um bom desenvolvimento das plantas. Já na etapa reprodutiva, as plantas sofreram a incidência das baixas temperaturas e do menor fotoperíodo resultando numa menor produção de grãos e, portanto num menor índice de colheita.

Tabela 15 - Altura da planta (AP) e espiga (AE) e Ciclo vegetativo (C.V) PiracicabaÉpoca normal.

\begin{tabular}{|c|c|c|c|c|c|c|}
\hline \multirow{2}{*}{$\begin{array}{l}\text { Material } \\
\text { SIKALQ }\end{array}$} & \multicolumn{2}{|c|}{$\begin{array}{l}\mathbf{A P}{ }^{\mathrm{NS}} \\
(\mathrm{cm})\end{array}$} & \multicolumn{2}{|c|}{$\begin{array}{l}\mathbf{A E} * * \\
(\mathrm{~cm})\end{array}$} & \multicolumn{2}{|c|}{$\begin{array}{l}\mathbf{C V * *} \\
\text { (dias) }\end{array}$} \\
\hline & 184,8 & $\mathrm{~A}$ & 93,8 & $\mathrm{AB}$ & 49,7 & $\mathrm{C}$ \\
\hline EPB2-3A & 178,5 & A & 94,1 & $\mathrm{AB}$ & 53,7 & A \\
\hline C-1 TSN & 177,0 & A & 96,9 & $\mathrm{AB}$ & 51,0 & $\mathrm{BC}$ \\
\hline C-1 SSN & 183,6 & A & 98,1 & $A B$ & 52,0 & $\mathrm{AB}$ \\
\hline C-1 TSA & 181,8 & A & 102,4 & A & 51,5 & $\mathrm{BC}$ \\
\hline C-1 SSA & 178,8 & A & 100,0 & $\mathrm{AB}$ & 51,2 & $\mathrm{BC}$ \\
\hline TT & 174,5 & A & 84,6 & $\mathrm{C}$ & 50,0 & $\mathrm{BC}$ \\
\hline TS & 176 & A & 91,4 & $\mathrm{BC}$ & 51,2 & $\mathrm{BC}$ \\
\hline CVe \% & \multicolumn{2}{|c|}{10,34} & \multicolumn{2}{|c|}{14,21} & \multicolumn{2}{|c|}{2,38} \\
\hline
\end{tabular}

*; **, Diferenças significativas ao 5 e $1 \%$ e ns, diferenças não significativas Médias seguidas pela mesma letra não diferem estatisticamente para o teste de Duncan. CVe: Coeficiente de Variação Experimental. 
O caráter ciclo vegetativo foi menos afetado pelas condições ambientais da época normal que os outros caracteres estudados. Os materiais avaliados apresentaram um período de emergência até o florescimento apenas inferior ao observado em safrinha, evidenciando a forte influência da nutrição mineral e da disponibilidade de água no desenvolvimento da cultura de milho.

\subsubsection{Experimentos em época normal - Fazenda Anhembi, Anhumas SP.}

Assim como observado no experimento de Piracicaba, os dois de Anhumas foram afetados positivamente pelas melhores condições ambientais existentes na época normal de plantío. A produção de MST apresentou, nos dois experimentos um forte aumento em relação à época de safrinha. O comportamento médio dos materiais nas duas condições de solo aumentou em aproximadamente $60 \%$, evidenciando o efeito das melhores condições de temperatura, irradiação e água, existentes na época normal.

Nos dois experimentos foram verificadas diferenças estatisticamente significativas entre os materiais avaliados (Tabela 16). Foi também possivel confirmar o efeito do cruzamento introgressivo com SIKUANI, porque nas duas condições de solo avaliadas, a população resultante da introgressão (SIKALQ) foi superior à população local, assim como o efeito dos processos de seleção divergente realizados, uma vez que em todos os casos as populações tolerantes produziram mais MST do que a suscetiveis embora essas diferenças, expressas em quilogramas de MST por hectare, não sejam muito importantes.

Paralelamente ao aumemento observado na produção de MST (Tabela 16) e da produção de grãos (Tabela 17) foi possivel observar uma alteração sensivel no IC .

Quando comparados com os valores observados em safrinha, no experimento em solo álico houve uma leve redução dos IC dos materiais, o que poderia ser explicado pelo fato de que as melhores condições ambientais favoreceram mais a produção de MST do que a produção de grãos. Ao contrário do observado no experimento em solo corrigido onde embora MST e produção aumentaram muito, o melhor estado nutricional do solo 
permitiu um melhor aproveitamento das condições ambientais favorecendo uma adequada partição dos assimilados.

Tabela 16 - Matéria seca total (MST) e Índice de colheita (IC) nas duas condições de solo Anhembi - Época normal.

\begin{tabular}{|c|c|c|c|c|c|c|c|c|}
\hline \multirow{3}{*}{$\begin{array}{l}\text { Local } \\
\text { Material } \\
\text { SIKALQ }\end{array}$} & \multirow{2}{*}{\multicolumn{2}{|c|}{$\begin{array}{c}\text { Solo Ácido } \\
\text { MST ** } \\
\left(\mathrm{Kg} \mathrm{ha}^{-1}\right)\end{array}$}} & \multirow{2}{*}{\multicolumn{2}{|c|}{$\begin{array}{c}\text { Solo Corrigido } \\
\text { MST }^{*} \\
\left(\mathrm{Kg} \mathrm{ha}^{-1}\right)\end{array}$}} & \multirow{2}{*}{\multicolumn{2}{|c|}{$\begin{array}{l}\text { Solo Ácido } \\
\text { IC * } \\
(\%)\end{array}$}} & \multirow{2}{*}{\multicolumn{2}{|c|}{$\begin{array}{c}\text { Solo Corrigido } \\
\text { IC }^{\mathrm{NS}} \\
(\%) \\
\end{array}$}} \\
\hline & & & & & & & & \\
\hline & 12325,0 & $B C$ & 15111,1 & $\mathrm{BC}$ & 29,5 & $\mathrm{BC}$ & 42,6 & $A$ \\
\hline EPB2-3A & 11262,5 & $\mathrm{D}$ & 14333,3 & $\mathrm{C}$ & 28,8 & $\mathrm{C}$ & 39,7 & $\mathrm{~A}$ \\
\hline C-1 TSN & 12608,3 & $\mathrm{ABC}$ & 16333,3 & $\mathrm{ABC}$ & 32,5 & A & 40,8 & $\mathrm{~A}$ \\
\hline C-1 SSN & 11309,7 & $\mathrm{D}$ & 16055,5 & $\mathrm{ABC}$ & 32,2 & A & 37,5 & $\mathrm{~A}$ \\
\hline C-1 TSA & 12891,7 & $\mathrm{AB}$ & 16277,8 & $\mathrm{ABC}$ & 32,5 & A & 42,3 & A \\
\hline C-1 SSA & 11640,3 & $\mathrm{CD}$ & 15138,9 & $\mathrm{BC}$ & 26,2 & $\mathrm{D}$ & 39,7 & A. \\
\hline TT & 13316,7 & A & 17694,4 & A & 31,7 & $\mathrm{AB}$ & 40,3 & A \\
\hline TS & 12230,6 & $\mathrm{BCD}$ & 17194,4 & $\mathrm{AB}$ & 30,5 & $\mathrm{ABC}$ & 39,4 & $\mathrm{~A}$ \\
\hline CVe \% & 14,2 & & 17,1 & & & & & \\
\hline
\end{tabular}

*: **, Diferenças significativas ao 5 e $1 \%$ e ns, diferenças não significativas

Médias seguidas pela mesma letra não diferem estatisticamente para o teste de Duncan.

CVe: Coeficiente de Variação Experimentak.

A baixa disponibilidade de nutrientes, em especial de fósforo e nitrogênio, afetou a eficiência de utilização da radiação incidente e a partição dos assimilados para a produção de grão. Andrade et al. (1996) reportaram que a deficiência de nutrientes, em especial de nitrogênio seria um dos principais fatores responsáveis pela diminuição da eficiência fotossintética em espécies de metabolismo $\mathrm{C}_{4}$ como o milho. Provavelmente, essa queda na eficiência fotossintética seja devida a uma menor quantidade de radiação absorvida devido à redução na expansão foliar (Murchow, 1988) e por uma menor 
eficiência de conversão dessa radiação incidente como resposta aos baixos conteúdos de nitrogênio em folha (Novoa \& Loomis, 1981).

Embora o comportamento diferente do IC nos dois experimentos, verificou-se que os materiais considerados tolerantes apresentaram um IC superior aos suscetiveis, confirmando a tendência observada na produção de MST (Tabela 16) e na PL (Tabela 17).

O caráter PL foi um dos mais influenciados pelas melhores condições ambientais encontradas pelos materiais na época normal de plantio. Contrariamente ao observado em safrinha, onde a PL média de todos os tratamentos do experimento em solo corrigido foi apenas superior à do experimento de solo ácido, a disponibilidade de água e em especial de radiação incidente mais altas, permitiram um melhor aproveitamento do agregado de nutrientes e, portanto, a obtenção de uma maior produção de grãos. Este aumento produzido principalmente pela maior disponibilidade de radiação incidente coincide com o reportado por Uhart \& Andrade (1991) e por Andrade et al. (1993) para a cultura de milho. Essa resposta à maior radiação incidente observada no experimento com maior disponibilidade de nutrientes, em especial o nitrogênio, pode ser explicada pelo fato de que esses são os dois fatores mais importantes no aumento da fotossintese e da eficiência de conversão em espécies $C_{4}$ (Andrade et al, 1996).

Embora esse forte aumento na PL observado nos experimentos de época normal, especialmente em solo corrigido, foi possivel observar entre os materiais a mesma tendência nos rendimentos observada em safrinha, resultando em todos os casos os materiais tolerantes superiores aos suscetíveis.

No experimento em solo ácido (Figura $10 \mathrm{~A}$ ) o efeito da introgressão de SIKUANI em EPB2-3A foi confirmado porque SIKALQ apresentou uma PL 14,4\% superior à população local. As duas populações selecionadas como tolerantes resultaram superiores as suscetíveis. Neste experimento a seleção em vasos com solo álico apresentou-se como mais eficiente porque a população obtida por esta metodologia (C1TSA), apresentou uma PL aproximadamente $3 \%$ superior à obtida por seleção em solução nutritiva (C-1 TSN) e por apresentar uma maior diferença entre as populações 
divergentes. Assim a PL de C-1TSA foi 42,8 \% superior em relação a C-1 SSA enquanto a diferença entre C-1TSN e C-1SSN foi de $15,3 \%$.

As testemunhas, como nos outros experimentos em condições de acidez, foram contrastantes e TT apresentou uma PL 14,5\% superior à TS.

No experimento em solo corrigido (Figura $10 \mathrm{~B}$ ), os materiais avaliados apresentaram um comportamento semelhante ao observado no experimento em solo ácido, e todos os tolerantes apresentaram uma PL superior aos suscetiveis, embora essas diferenças tenham sido menores às observadas no experimento sem agregado de nutrientes, provavelmente como resultado do menor nível de estresse.

Os híbridos utilizados como testemunhas apresentaram os maiores rendimentos, com TT superando a TS em 6\%. A população C-1TSA apresentou uma PL aproximadamente $2 \%, 11,0 \%$ e $16,5 \%$ superior a C-1 TSN, C-1SSA e SIKALQ, respectivamente.
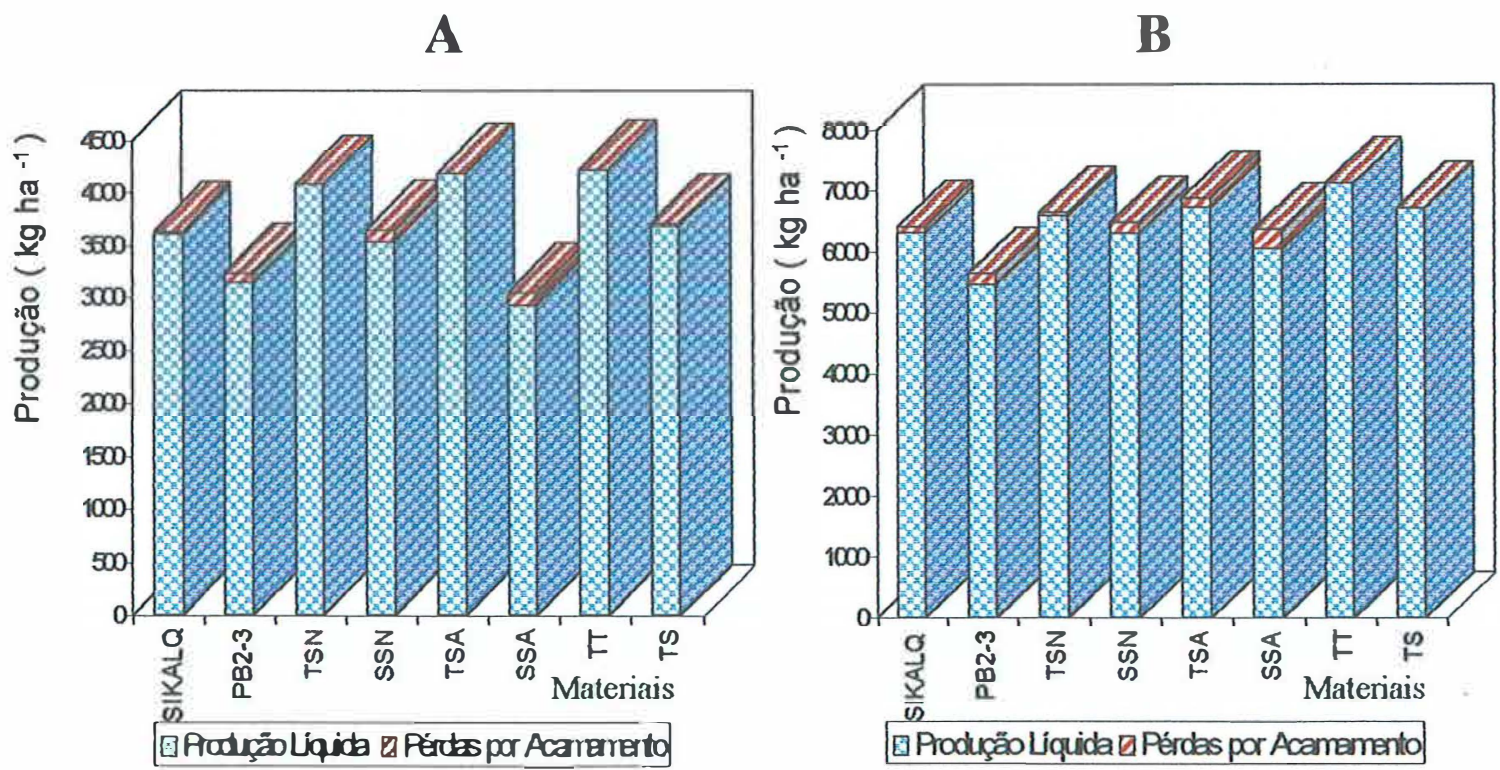

Figura 10 - Produção líquida de grãos (PL) em solo ácido (A) e corrigido (B) AnhumasÉpoca normal. 
O caráter acamamento foi fortemente influenciado pelas condições ambientais da época normal de plantio. Igualmente ao observado no local Piracicaba, houve uma redução importante no acamamento apresentado pelos materiais avaliados em relação a safrinha, indicando uma forte associação entre as condições ambientais e a ocorrência de acamamento. Em geral o experimento em solo corrigido apresentou valores sensivelmente superiores aos observados no experimento em solo ácido, devido principalmente a maior altura da planta e espiga, associados a maior produção de grãos.

Quando comparados com safrinha, a redução mais importante na porcentagem de acamamento ocorreu no experimento de solo corrigido que apresentou uma queda de aproximadamente $60 \%$.

Tabela 17 - Produção líquida de grãos (PL) e Acamamento (AC) nas duas condições de solo Anhembi - Época normal

\begin{tabular}{|c|c|c|c|c|c|c|c|c|}
\hline \multirow{3}{*}{$\begin{array}{l}\text { Local } \\
\text { Material } \\
\text { SIKALQ }\end{array}$} & \multirow{2}{*}{\multicolumn{2}{|c|}{$\begin{array}{c}\text { Solo Ácido } \\
\text { PL * } \\
\left(\mathrm{Kg} \mathrm{ha}^{-1}\right)\end{array}$}} & \multirow{2}{*}{\multicolumn{2}{|c|}{$\begin{array}{c}\text { Solo Corrigido } \\
\text { PL }^{*} \\
\left(\mathrm{Kg} \mathrm{ha}^{-1}\right) \\
\end{array}$}} & \multirow{2}{*}{\multicolumn{2}{|c|}{$\begin{array}{c}\text { Solo Ácido } \\
\mathrm{AC}^{* *} \\
(\%) \\
\end{array}$}} & \multirow{2}{*}{\multicolumn{2}{|c|}{$\begin{array}{c}\text { Solo Corrigido } \\
\mathbf{A C} \\
(\%) \\
\end{array}$}} \\
\hline & & & & & & & & \\
\hline & 3605.2 & $\mathrm{ABC}$ & 6315.4 & $\mathrm{AB}$ & 0,8 & $\mathrm{BC}$ & 1,4 & $\mathrm{~A}$ \\
\hline EPB2-3A & 3147.2 & $\mathrm{BC}$ & 5454.1 & B & 2,5 & $\mathrm{AB}$ & 3,1 & A \\
\hline C-1 TSN & 4078.3 & $\mathrm{AB}$ & 6588.5 & A & 0,0 & $\mathrm{C}$ & 0,7 & A \\
\hline C-1 SSN & 3537.0 & $\mathrm{ABC}$ & 6297.0 & $\mathrm{AB}$ & 3,1 & A & 3,1 & A \\
\hline C-1 TSA & 4186.3 & $\mathrm{AB}$ & 6730.5 & A & 0,0 & $\mathrm{C}$ & 2,1 & A \\
\hline C-1 SSA & 2930.8 & $\mathrm{C}$ & 6065.4 & $\mathrm{AB}$ & 4,3 & A & 4,5 & A \\
\hline $\mathrm{TT}$ & 4218.5 & A & 7123.4 & A & 0,0 & $\mathrm{C}$ & 0,0 & A \\
\hline TS & 3683.1 & $\mathrm{ABC}$ & 6721.4 & A & 0,6 & $\mathrm{BC}$ & 0,0 & A \\
\hline CVe \% & \multicolumn{2}{|c|}{17.32} & \multicolumn{2}{|c|}{10.30} & \multicolumn{2}{|c|}{91,2} & \multicolumn{2}{|c|}{47,23} \\
\hline
\end{tabular}

*: **, Diferenças significativas ao 5 e $1 \%$ e ns. diferenças não signifícativas Médias seguidas pela mesma letra não diferem estatisticamente para o teste de Duncan.

CVe: Coeficiente de Variação Experimental. 
Tanto no experimento de solo ácido como corrigido, os materiais considerados tolerantes apresentaram um comportamento superior em relação aos suscetiveis. Os híbridos comerciais utilizados como testemunhas apresentaram os melhores valores de acamamento (Tabela 17).

Outros caracteres influenciados pelas condições ambientais da época normal de plantio foram AP e AE. Tanto no experimento em solo ácido como em solo corrigido, a $\mathrm{AP}$ e $\mathrm{AE}$ foram aproximadamente $10 \%$ maiores do que os respectivos experimentos em safrinha, e foi possível confirmar a marcante diferença de altura observada em safrinha entre as duas condições de solo. Em todos os casos, os materiais tolerantes apresentaram uma AP e AE maior do que os suscetiveis e como esperado, os híbridos comerciais apresentaram os menores valores de AE.

Tabela 18 - Altura da planta (AP) e espiga (AE) nas duas condições de solo Anhembi Época normal

\begin{tabular}{|c|c|c|c|c|c|c|c|c|}
\hline \multirow{2}{*}{$\begin{array}{l}\text { Local } \\
\text { Material } \\
\end{array}$} & \multirow{2}{*}{\multicolumn{2}{|c|}{ 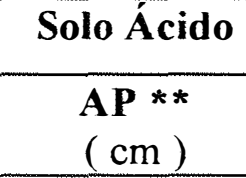 }} & \multirow{2}{*}{\multicolumn{2}{|c|}{ 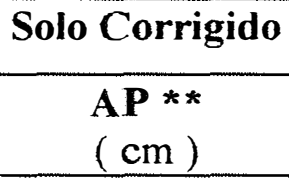 }} & \multirow{2}{*}{\multicolumn{2}{|c|}{ 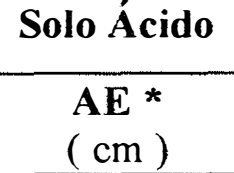 }} & \multirow{2}{*}{\multicolumn{2}{|c|}{ 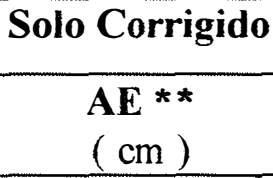 }} \\
\hline & & & & & & & & \\
\hline SIKALQ & 147,5 & $\mathrm{BC}$ & $192 ; 8$ & $\mathrm{AB}$ & 72,1 & $\mathrm{~A}$ & 110,0 & $\mathrm{BCD}$ \\
\hline EPB2-3A & 140,5 & $\mathrm{C}$ & 186,5 & BC & 75,8 & A & 114,8 & B \\
\hline C-1 TSN & 153,4 & A & 187,5 & $\mathrm{BC}$ & 75,4 & A & 112,9 & $\mathrm{BC}$ \\
\hline C-1 SSN & 143,8 & $\mathrm{BC}$ & 182,7 & $\mathrm{C}$ & 69,9 & $\mathrm{AB}$ & 109,8 & $\mathrm{BCD}$ \\
\hline C-1 TSA & 155,1 & A & 195,3 & A & 71,0 & $\mathrm{AB}$ & 124,2 & A \\
\hline C-1 SSA & 151,1 & $\mathrm{AB}$ & 184,7 & $\mathrm{C}$ & 75,2 & A & 104,5 & $\mathrm{CD}$ \\
\hline TT & 144,4 & $\mathrm{BC}$ & 186,7 & $\mathrm{BC}$ & 68,6 & $\mathrm{AB}$ & 109,1 & $\mathrm{BCD}$ \\
\hline TS & 138,9 & $\mathrm{C}$ & 185,3 & $\mathrm{BC}$ & 62,9 & B & 102,4 & D \\
\hline CVe \% & & & & & & & & \\
\hline
\end{tabular}

*: **. Diferenças significativas ao 5 e $1 \%$ e ns, diferenças não significativas Médias seguidas pela mesma letra não diferem estatisticamente para o teste de Duncan.

CVe: Coeficiente de Variação Experimental. 
$\mathrm{O}$ caráter $\mathrm{CV}$, semelhante ao observado em Piracicaba, foi pouco influenciado pela condições da época normal. Em geral houve uma redução na quantidade de dias necessários para atingir o florescimento em todos os materiais.

Foi possivel confirmar o efeito do cruzamento introgressivo de SIKUANI porque a população local apresentou um ciclo mais longo do que SIKALQ e as derivadas dela por seleção (Tabela 19).

Assim como nas condições de safrinha, foi observada nos materiais suscetiveis uma marcante tendência a aumentar o ciclo vegetativo quando submetidos a um maior nivel de estresse.

Tabela 19 - Ciclo vegetativo (CV) nas duas condições de solo Anhembi - Época normal.

\begin{tabular}{|c|c|c|c|c|}
\hline \multirow{2}{*}{$\begin{array}{l}\text { Local } \\
\text { Material } \\
\end{array}$} & \multicolumn{2}{|c|}{ Solo Ácido } & \multicolumn{2}{|c|}{ Solo Corrigido } \\
\hline & \multicolumn{2}{|c|}{$\begin{array}{l}\mathbf{C V}^{*} \\
\text { (dias) }\end{array}$} & \multicolumn{2}{|c|}{$\begin{array}{l}\mathbf{C V} * * \\
\text { (días) }\end{array}$} \\
\hline$\overline{\text { SIKALQ }}$ & 57,0 & $\mathrm{~A}$ & 50,5 & B \\
\hline EPB2-3A & 61,0 & A & 55,0 & A \\
\hline C-1 TSN & 56,0 & B & 52,5 & B \\
\hline C-1 SSN & 57,5 & $\mathrm{AB}$ & 52,5 & B \\
\hline C-1 TSA & 56,5 & B & 52,2 & B \\
\hline C-1 SSA & 58,0 & $\mathrm{AB}$ & 52,5 & B \\
\hline TT & 56,0 & B & 50,5 & B \\
\hline TS & 57,7 & $\mathrm{AB}$ & 52,0 & B \\
\hline CVe \% & \multicolumn{2}{|c|}{3,86} & \multicolumn{2}{|c|}{2,32} \\
\hline
\end{tabular}

*:**. Diferenças significativas ao 5 e $1 \%$ e ns, diferenças não significativas Médias seguidas pela mesma letra não diferem estatisticamente para o teste de Duncan. CVe: Coeficiente de Variação Experimental. 


\subsubsection{Experimento em época normal - EMBRAPA, Sete Lagoas MG.}

Este experimento foi realizado num solo típico do cerrado brasileiro, caracterizado por ser extremadamente ácido $(\mathrm{pH} 4,2)$ o que determinou uma baixa disponibilidade de elementos importantes como o fósforo e cálcio ( $<10$ ppm) e uma alta quantidade de alumínio trocável (52\%). Do ponto de vista nutricional, os materiais foram testados no pior ambiente de todos os utilizados. Esses problemas nutricionais ficaram evidentes ao analisar os resultados tanto de altura da planta (Tabela 20) quanto de produção de grãos (Figura 11, Tabela 20), os quais foram sensivelmente inferiores aos observados nos outros ambientes com alumínio.

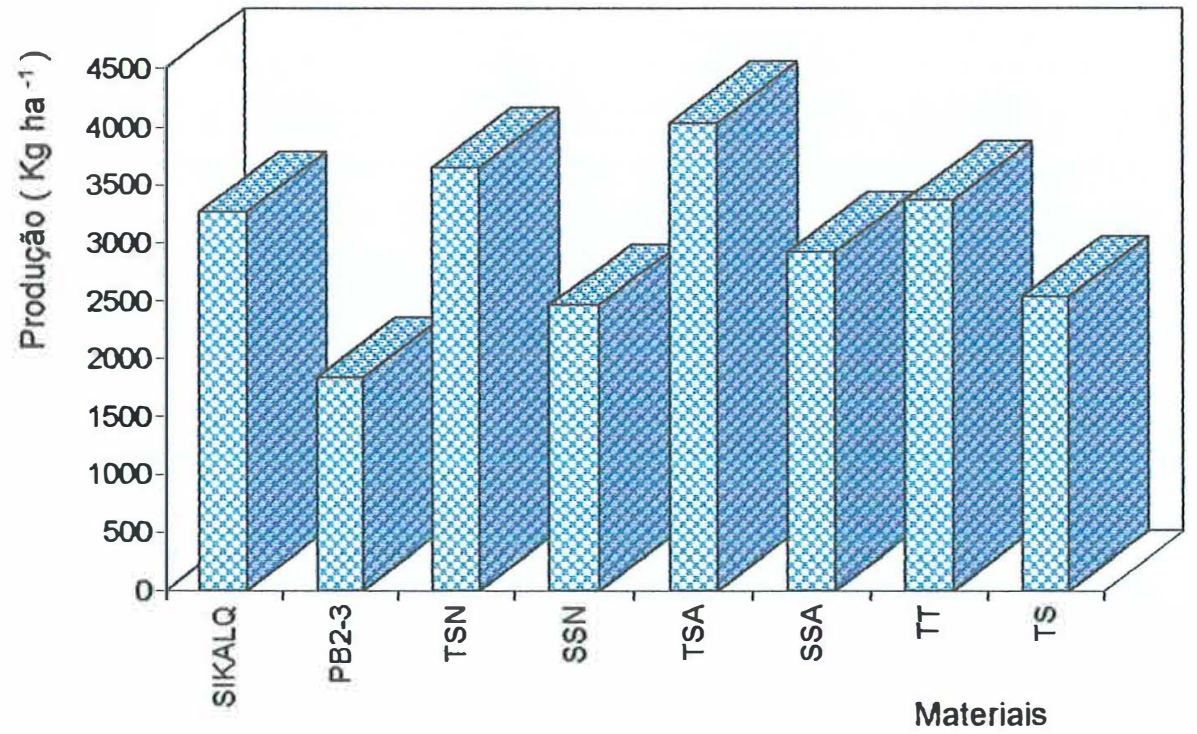

Figura 11 - Produção líquida (PL), Sete Lagoas- Época normal.

A PL que neste caso foi equivalente a produção total de grãos, foi a menor de todos os ambientes com alumínio, foi possível confirmar o efeito do cruzamento introgressivo de SIKUANI na população local, devido a que SIKALQ superou a 
EPB2-3A em 34,7 \% ( 3270,3 vs 2134,1 ). As duas populações selecionadas como tolerantes foram sensivelmente superiores à original e às suscetíveis. A população selecionada em vasos com solo álico (C-1 TSA) foi apenas superior à selecionada em solução nutritiva, superando-a em 10,6 \% (4039,1 vs 3649,2). Este resultado pode ser considerado como lógico porque essa população foi selecionada utilizando amostras de solo coletadas na mesma área do experimento.

Resumidamente, a população C-1 TSA apresentou uma produção de grãos $23,5 \%$ e $38,2 \%$ superior a SIKALQ e a C-1 SSA, respectivamente. Já a população C-1 TSN superou a SIKALQ e a C-1SSN em $11,6 \%$ e 47,9\%, respectivamente.

Assim como nos outros experimentos em solo ácido, as testemunhas foram contrastantes resultando a TT sensivelmente superior a TS ( $32,6 \%)$.

Devido à redução conjunta da altura da planta e da produção de grãos neste ambiente, não foram observadas plantas caidas. $\mathrm{O}$ mesmo aconteceu em Pindamonhangaba.

Embora a altura da planta tenha sido muito afetada pelas condições nutricionais adversas em todos os materiais, esse efeito foi muito mais importante nos materiais suscetíveis. Os dois híbridos comerciais utilizados como testemunhas apresentaram, os menores valores de altura da planta e da espiga.

$\mathrm{O} \mathrm{CV}$ foi muito afetado, principalmente pela baixa disponibilidade de fósforo e nitrogênio, sofrendo um marcante aumento na quantidade de dias necessários para atingir o florescimento e portanto, todos os materiais apresentaram o maior $\mathrm{CV}$ da época normal de plantio. 
Tabela 20 - Produção líquida (PL), Altura da planta (AP) e espiga (AE) e Ciclo vegetativo (CV), Sete Lagoas - Época normal.

\begin{tabular}{|c|c|c|c|c|c|c|c|c|}
\hline \multirow{2}{*}{$\begin{array}{l}\text { Material } \\
\text { SIKALQ }\end{array}$} & \multicolumn{2}{|c|}{$\begin{array}{c}\mathbf{P L}{ }^{* *} \\
\left(\mathrm{Kg} \mathrm{ha}^{-1}\right)\end{array}$} & \multicolumn{2}{|c|}{$\begin{array}{l}\mathbf{A P} * * \\
(\mathrm{~cm})\end{array}$} & \multicolumn{2}{|c|}{$\begin{array}{l}\mathbf{A E} * * \\
(\mathrm{~cm})\end{array}$} & \multicolumn{2}{|c|}{$\begin{array}{l}C V^{* *} \\
\text { (días) }\end{array}$} \\
\hline & 3270,3 & $\mathrm{ABCD}$ & 151,1 & $\mathrm{~A}$ & 67,8 & A & 64 & $\mathrm{C}$ \\
\hline EPB2-3A & 2134,1 & E & 137,7 & $\mathrm{BC}$ & 58,6 & C & 68,2 & A. \\
\hline C-1 TSN & 3649,2 & $\mathrm{AB}$ & 152,7 & A & 66,8 & $\mathrm{AB}$ & 63,7 & $\mathrm{C}$ \\
\hline C-1 SSN & 2467,7 & $\mathrm{DE}$ & 139,2 & $\mathrm{BC}$ & 58,4 & $\mathrm{C}$ & $65,5^{\circ}$ & B \\
\hline C-1 TSA & 4039,1 & A & 151,3 & A & 68,2 & $\mathrm{~A}$ & 63,5 & $\mathrm{C}$ \\
\hline C-1 SSA & 2922.9 & $\mathrm{BCD}$ & 142,5 & B & 61,8 & $\mathrm{BC}$ & 66,0 & B \\
\hline TT & 3366,9 & $\mathrm{ABC}$ & 133,8 & $\mathrm{C}$ & 52,2 & $\mathrm{D}$ & 64,0 & $\mathrm{C}$ \\
\hline TS & 2539,3 & $\mathrm{CDE}$ & 124,9 & D & 49,8 & D & 66,0 & B \\
\hline CVe \% & 17,78 & & 12,35 & & 20,42 & & 3,71 & \\
\hline
\end{tabular}

*; **, Diferenças significativas ao 5 e $1 \%$ e ns, diferenças não significativas Médias seguidas pela mesma letra não diferem estatisticamente para o teste de Duncan. CVe: Coeficiente de Variação Experimental.

\subsubsection{Experimentos de campo: Análise conjunta}

As análises em cada local de avaliação, com exceção dos locais de alta produtividade permitiram estabelecer comportamentos perfeitamente diferenciados entre os materiais tolerantes e os suscetíveis. Quando realizada a análise conjunta das sete variáveis (Tabela 21), foi possível verificar diferenças estatísticamente significativas entre locais para todas as variáveis, confirmando a correta escolha dos locais de avaliação. $\mathrm{O}$ fato de que todas as variáveis analisadas e em especial a produção de grãos apresentaram diferenças significativas entre ambientes, pode ser explicado em função das diferenças ambientais importantes entre as duas épocas de plantio e as diferenças nutricionais e de saturação de alumínio encontradas nos diferentes locais. 
Para todas as variáveis com exceção de MST, foram encontradas diferenças estatisticamente significativas entre materiais o que permitiu estabelecer tanto a eficiência dos processos de introgressão e seleção como da utilização de testemunhas contrastantes.

Tabela 21- Tabela de ANAVA conjunto.

\begin{tabular}{|c|c|c|c|c|c|c|c|c|}
\hline \multirow[b]{2}{*}{ F.V. } & \multirow[b]{2}{*}{ gl } & \multicolumn{7}{|c|}{ Valor $\mathbf{F}$} \\
\hline & & MST $^{1}$ & $I C^{1}$ & $\mathbf{P L}$ & $\mathrm{AC}$ & $\mathbf{A P}$ & $\mathbf{A E}$ & $\mathbf{C V}$ \\
\hline REP/LOCAIS & $\overline{24}$ & $4,6 * *$ & $1,2^{\mathrm{NS}}$ & $0,7^{\mathrm{NS}}$ & $1,1^{\mathrm{NS}}$ & $2 * *$ & $2 * *$ & $2,9 * *$ \\
\hline LOCAIS & 7 & $250,9 * *$ & $37,5 * *$ & $110,7 * *$ & $39,1 * *$ & $267,2 * *$ & $311,8^{* *}$ & $1064^{* *}$ \\
\hline MATERIAIS & 7 & $0,3^{\mathrm{NS}}$ & $7,8 * *$ & $9,3 * *$ & $1,9 *$ & $4,2 * *$ & $6,1 * *$ & $22,4 * *$ \\
\hline MAT $*$ LOCAIS & 49 & $1,4^{\mathrm{NS}}$ & $2,7 * *$ & $1,1^{\text {vs }}$ & $1,3 *$ & $0,7^{\mathrm{NS}}$ & $0,8^{\mathrm{NS}}$ & $3,3 * *$ \\
\hline ERRO MÉDIO & 168 & & & & & & & \\
\hline
\end{tabular}

; $^{* *}$, Diferenças significativas ao 5 e $1 \%$ e ns, diferenças não significativas.

${ }^{1}$ Não avaliados nos experimentos de Pindamonhangaba e Sete Lagoas.

A interação entre materiais e locais foi significativa apenas para $\mathrm{IC}, \mathrm{AC}$ e CV, três caracteres fortemente influenciados pelo ambiente, em especial AC e CV que tiveram um comportamento fortemente diferenciado pelas condições ambientais contrastantes nas duas épocas de plantio.

Os materiais avaliados, tanto a população local como SIKALQ e as resultantes dos processos de seleção, apresentaram um comportamento muito estável e coerente às suas características em todos os ambientes avaliados. Isto pode ser comprovado ao analisar os resultados quando os materias foram agrupados em ambientes em função da produtividade (Tabela 22). No ambiente de alta produtividade (AP), todos os materiais apresentaram uma boa produção de grãos. Embora as duas populações selecionadas como tolerantes tenham apresentado um rendimento inferior às suscetíveis, dificilmente essas diferenças permitiriam supor que a seleção para tolerância a acidez do solo estaria 
relacionada com uma queda no potencial produtivo em condições de alta produtividade. $\mathrm{Na}$ medida em que o estresse nutricional foi maior as diferenças entre os materiais. ficaram mais evidentes.

Tabela 22 - Produção líquida média dos materiais avaliados em todos os ambientes (TA), nos ambientes de produtividade alta (PA), de produtividade intermediaria alta (IA), intermediaria baixa (IB) e baixa produtividade (PB).

\begin{tabular}{|c|c|c|c|c|c|}
\hline \multirow[b]{2}{*}{ Material } & \multicolumn{5}{|c|}{ PL } \\
\hline & $\begin{array}{c}\mathbf{T A} \\
\left(\mathrm{Kg} \mathrm{ha}^{-1}\right)\end{array}$ & $\begin{array}{c}\text { PA } \\
\left(\mathrm{Kg} \mathrm{ha}^{-1}\right)\end{array}$ & $\begin{array}{c}\mathbf{I A} \\
\left(\mathrm{Kg} \mathrm{ha}^{-1}\right)\end{array}$ & $\begin{array}{c}\text { IB } \\
\left(\mathrm{Kg} \mathrm{ha}^{-1}\right)\end{array}$ & $\begin{array}{c}\text { PB } \\
\left(\mathrm{Kg} \mathrm{ha}^{-1}\right)\end{array}$ \\
\hline SIKALQ & 4272,3 & 5284,2 & 5550,4 & 3232,9 & 3021,9 \\
\hline EPB2-3A & 3930,8 & 5643,2 & 4956,8 & 2938,8 & 2184,4 \\
\hline C-1 TSN & 4733,3 & 6122,6 & 5710,6 & 3759,9 & 3340,0 \\
\hline C-1 SSN & 3976,4 & 5433,7 & 4842,3 & 3129,1 & 2500,6 \\
\hline C-1 TSA & 4856,8 & 5867,9 & 5975,5 & 3975,3 & $3608 ; 5$ \\
\hline C-1 SSA & 4285,2 & 6285,3 & 5399,2 & 2847,8 & 2608,5 \\
\hline TT & $5361 ; 5$ & 7598,0 & 6752,4 & 3659,4 & 3436,2 \\
\hline TS & 4649,2 & 6824,2 & 6084,0 & 3167,2 & 2521,4 \\
\hline
\end{tabular}




\subsection{3- Experimentos em casa de vegetação}

\subsubsection{1- Experimento em vasos com solo álico}

No experimento realizado em vasos com solo álico foram observados resultados coerentes com os obtidos em solução nutritiva (Tabela 23). Para todos os caracteres avaliados houve um grande efeito tanto do cruzamento introgressivo como dos processos de seleção divergente.

Tabela 23 - Área foliar (AF), Peso fresco de raiz (PFR) e Peso seco de raiz (PSR) e Avaliação visual (AV) no experimento em vasos com solo álico.

\begin{tabular}{|c|c|c|c|c|c|c|c|c|}
\hline \multirow{2}{*}{$\begin{array}{l}\text { Material } \\
\text { SIKALQ }\end{array}$} & \multicolumn{2}{|c|}{$\begin{array}{l}\mathbf{A F}^{* *} \\
\left(\mathrm{~cm}^{2}\right)\end{array}$} & \multicolumn{2}{|c|}{$\begin{array}{c}\text { PFR** } \\
(\mathrm{g})\end{array}$} & \multicolumn{2}{|c|}{$\begin{array}{l}\text { PSR ** }^{*} \\
(\mathrm{~g})\end{array}$} & \multicolumn{2}{|c|}{$\begin{array}{c}\mathbf{A V} \\
(\text { nota })\end{array}$} \\
\hline & 432,5 & $\mathrm{BC}$ & 37,4 & $\mathrm{BCD}$ & 1,5 & $\mathrm{CD}$ & 3,5 & $\mathrm{C}$ \\
\hline EPB2-3A & 398,9 & $\mathrm{C}$ & 36,5 & $\mathrm{CD}$ & 1,4 & $\mathrm{D}$ & 2,5 & $E$ \\
\hline C-1 TSN & 494,8 & $\mathrm{AB}$ & 41,8 & $A B$ & 1,7 & $\mathrm{BC}$ & 4,3 & A \\
\hline C-1 SSN & 409,1 & $\mathrm{C}$ & 35,8 & $\mathrm{CD}$ & 1,5 & $\mathrm{CD}$ & 2,8 & $\mathrm{D}$ \\
\hline C-1 TSA & 560,7 & A & 44,7 & A & 1,8 & $\mathrm{AB}$ & 4,5 & A \\
\hline C-1 SSA & 430,2 & $\mathrm{BC}$ & 36,2 & $\mathrm{CD}$ & 1,6 & D & 2,7 & ED \\
\hline TT & 456,6 & $\mathrm{BC}$ & 39,4 & $\mathrm{BC}$ & 2,0 & A & 4,5 & $\mathrm{~A}$ \\
\hline TS & 383,1 & $\mathrm{C}$ & 32,9 & D & 1,4 & $\mathrm{CD}$ & 3,8 & B \\
\hline CVe \% & \multicolumn{2}{|c|}{11,45} & \multicolumn{2}{|c|}{8,17} & \multicolumn{2}{|c|}{7,04} & \multicolumn{2}{|c|}{5,82} \\
\hline
\end{tabular}

Para todos os caracteres avaliados, a população SIKALQ apresentou um aumento em relação à população local, sendo $8,4 \%, 2,6 \%$ e $11,0 \%$ superior para os caracteres área foliar (AF), peso fresco de raiz (PFR) e peso seco de raiz (PSR), respectivamente. Já as selecionadas como tolerantes apresentaram um comportamento semelhante entre 
elas e sensivelmente superior a SIKALQ e as suscetiveis. Assim C-1 TSN apresentou um aumento de $14,4 \%, 11,8 \%$ e 16,2\% superior a SIKALQ e de 20,9\%, 16,8 e 17, $8 \%$ superior a C-1 SSN para os três caracteres avaliados, respectivamente. Situação similar ocorreu com C-1 TSA que superou a SIKALQ em 29,6\%, 19,6\% e19,5\% e a C-1 SSA em 20,9\%, 16,8\%, 17,8\% nos caracteres AF, PFR e PSR, respectivamente. Para esses caracteres, as testemunhas foram suficientemente contrastantes já que TT sueprou a TS em $19,2 \%$ para AF, $19,8 \%$ para PFR e $45,9 \%$ para PSR.

\subsubsection{2- Experimento em solução nutritiva.}

\subsubsection{1- Comportamento dos materiais}

Os resultados obtidos no experimento comparando o comportamento das populações em solução nutritiva é apresentado na Tabela 24. Neles é possivel verificar que houve diferenças estatísticas altamente significativas entre as populações estudadas.

Da observação desses valores seria possivel inferir que houve um efeito positivo da introgressão na tolerância ao alumínio pela utilização de SIKUANI no cruzamento com a população local que pode ser visualizado através do comportamento médio de cada população. Assim a população resultante da introgressão (SIKALQ) apresentou um crescimento líquido da raiz principal de $9,7 \mathrm{~mm} \mathrm{dia}^{-1}$, enquanto a população local apresentou uma redução sensivel no crescimento radicular, sendo sua média de $8,4 \mathrm{~mm}$ $\operatorname{dia}^{-1}$. De maneira análoga, a seleção para crescimento radicular em solução nutritiva foi muito eficiente em diferenciar individüos tolerantes dos sensiveis ao alumínio. A eficiência dessa metodologia de seleção pode ser observada claramente quando são comparados o crescimento líquido da população selecionada como tolerante (C-1 TSN)

de $12,1 \mathrm{~mm} \mathrm{dia}^{-1}$, que resultou o maior entre todas as populações avaliadas com a população selecionada como suscetivel (C-1 SSN) que apresentou um dos menores valores de crescimento $\left(7,2 \mathrm{~mm} \mathrm{dia}^{-1}\right)$.

Tabela 24 - Crescimento liquido da raiz (CLR) em solução nutritiva. 
Tabela 24 - Crescimento líquido da raiz (CLR) em solução nutritiva.

\begin{tabular}{|c|c|c|}
\hline Material & $\begin{array}{c}\text { CLR ** } \\
\left(\mathrm{mm} \mathrm{dia}^{-1}\right)\end{array}$ & \\
\hline SIKALQ & 9,7 & A \\
\hline PB2-3A & 8,4 & B \\
\hline C-1 TSN & 12,1 & B \\
\hline C-1 SSN & 7,2 & B \\
\hline C-1 TSA & 10,0 & $\mathrm{C}$ \\
\hline C-1 SSA & 8,4 & $\mathrm{C}$ \\
\hline TT & 10,6 & $\mathrm{D}$ \\
\hline TS & 5,4 & $\mathrm{E}$ \\
\hline CVe \% & 19.87 & \\
\hline
\end{tabular}

Já as populações selecionadas utilizando vasos com solo álico, quando avaliadas em solução nutritiva apresentaram valores de crescimento líquido intermediário, resultando o comportamento da tolerante (C-1 TSA) muito semelhante a SIKALQ (10,0 $\mathrm{mm}$ dia $^{-1}$ e 9,7 mm dia ${ }^{-1}$, respectivamente). O comportamento da população selecionada como suscetível (C-1 SSA) apresentou um comportamento similar a PB2-3A $(8,4 \mathrm{~mm}$ $\mathrm{dia}^{-1}$ e $8,4 \mathrm{~mm} \mathrm{dia}^{-1}$, respectivamente).

Em relação às testemunhas, mais uma vez apresentaram-se suficientemente contrastantes permitindo caracterizar o comportamento das populações em estudo. A testemunha tolerante, o hibrido simples DINA 766, apresentou um alto valor de crescimento líquido $\left(10,6 \mathrm{~mm} \mathrm{dia}^{-1}\right)$ perdendo unicamente para C-1 TSN. Já a testemunha sensível, o híbrido simples MITLA 9560, apresentou o pior comportamento entre todos os materiais avaliados $\left(5,4 \mathrm{~mm} \mathrm{dia}^{-1}\right)$. 


\subsubsection{2 -Cálculo do progresso obtido por seleção utilizando solução nutritiva}

O progresso observado por seleção para a população tolerante (C-1 TSN) foi de $2,3 \mathrm{~mm} \mathrm{dia}^{-1}$, como resultado da diferença entre o comportamento dela $\left(12,1 \mathrm{~mm} \mathrm{dia}^{-1}\right)$ em relação a SIKALQ $\left(9,7 \mathrm{~mm} \mathrm{dia}^{-1}\right)$. Já a população suscetivel apresentou um progresso negativo de $-2,51 \mathrm{~mm}$ dia $^{-1}$ como resultado do processo de seleção para menor crescimento da raiz.

Os valores de progresso por seleção observados resultam inferiores aqueles estimados durante o teste de progênies (Quarta etapa). Assim, quando foram comparados os valores de progresso estimados teoricamente $\left(3,1 \mathrm{~mm} \mathrm{dia}^{-1}\right.$ e $-3,9 \mathrm{~mm} \mathrm{dia}^{-1}$ para a população tolerante e suscetivel, respectivamente), obtidos combinando o coeficiente de herdabilidade estimado e o diferencial de seleção com aqueles realmente obtidos, foi possivel verificar que houve diferenças e que em ambos os casos aconteceu uma superestimação do progresso por seleção, sendo que a maior diferença ocorreu para a população suscetivel. Essa situação está em concordância com Hallauer \& Miranda Filho (1988). Esses autores sugeriram que progressos estimados teoricamente sejam superiores aqueles obtidos. Essa situação poderia ser o resultado de problemas durante a amostragem ou algum tipo de efeito da interação genótipo-ambiente. As diferenças aqui observadas poderiam ser explicadas como uma possivel superestimação do coeficiente de herdabilidade ou devido ao fato de que durante o transplante no campo das plântulas selecionadas, algumas delas morreram devido ao estresse do transplante e essa situação poderia ter modificado o comportamento final de cada uma dessas populações. 


\subsubsection{Associação entre os experimentos de campo e em casa de vegetação}

Com o objetivo de estimar o grau de associação existente entre os resultados obtidos nos dois experimentos em casa de vegetação e, em especial, das variáveis utilizadas como critérios de seleção nos processos de seleção divergente, foram calculados os coeficientes de correlação entre essas variáveis e a produção de grãos no campo (Tabela 25).

Quando analisados os coeficientes de correlação calculados entre as diferentes. variáveis medidas em casa de vegetação, foi possível estabelecer valores intermediários a altos de correlação entre elas, variando de 0,47 para AV e CLR até 0,79 para PSR e PFR. Todas as correlações foram significativas.

Tabela 25 - Associação entre Produção Total de grãos, medida no campo com Crescimento líquido da raiz (CLR), Área foliar (AF), Peso fresco da raiz (PFR) e Peso seco da raiz (PSR) e Avaliação visual (AV) medidos em casa de vegetação.

\begin{tabular}{|c|c|c|c|c|c|c|c|c|c|}
\hline \multirow[b]{2}{*}{ Caráter } & \multicolumn{5}{|c|}{ Casa de vegetação } & \multicolumn{4}{|c|}{ Campo } \\
\hline & CLR & $\mathbf{A F}$ & PFR & PSR & AV & PA & IA & IB & $\mathbf{B P}$ \\
\hline CLR & & & & & & $0,02^{\mathrm{NS}}$ & $0,25^{\mathrm{NS}}$ & $0,39 *$ & $0,52 * *$ \\
\hline AF & $0,52 * *$ & & & & & $-0,05^{\mathrm{NS}}$ & $0,29^{\mathrm{NS}}$ & $0,43 * *$ & $0,44 * *$ \\
\hline PFR & $0,57 * *$ & $0,62 * *$ & & & & $0,30^{N S}$ & $0,43 * *$ & $0,40 *$ & $0,47 * *$ \\
\hline PSR & $0,56 * *$ & $0.78 * *$ & $0,79 * *$ & & & $-0,03$ NS & $0,24^{\mathrm{NS}}$ & $0,41 * *$ & $0,42 * *$ \\
\hline AV & $0,47 * *$ & $0,53 * *$ & $0,60 * *$ & $0,51 * *$ & & $0,20^{\mathrm{is}}$ & $0,46 * *$ & $0,50 * *$ & $0,68 * *$ \\
\hline
\end{tabular}

$\mathrm{PA}=$ Alta. $\mathrm{IA}=$ Intermediaria alta. $\mathrm{IB}=$ Intermediaria baixa e $\mathrm{BP}=$ baixa produtividade, respectivamente. *: **, Diferenças significativas ao 5 e $1 \%$ e ns. diferenças não significativas. 
Os resultados mais interessantes foram obtidos na análise das correlações das variáveis medidas em casa de vegetação e a produção nos ambientes com diferentes produtividades. As correlações foram muito baixas e até negativas com a produção obtida no ambiente PA e aumentaram significativamente na medida em que aumentou o nível de estresse nutricional e especialmente de alumínio. Esse comportamento poderia ser explicado em função de que todas as variáveis de casa de vegetação foram medidas em condições de elevado estresse, completamente diferentes às encontradas no ambiente PA. Os melhores valores de correlação foram obtidos para as duas variáveis utilizadas como critérios de seleção. Assim, a variável AV utilizada como critério de seleção no metodo 1 , apresentou a melhor correlação $(0,68)$, enquanto que a correlação entre CLR (método2) e a produção foi de 0,52 .

\section{4 - QUARTA ETAPA: Teste de progênies e estimação de parâmetros genéticos}

\subsection{1 - Estimação dos componentes da variância e do coeficiente de herdablidade.}

As 99 progênies de meios irmãos avaliadas (Figura 12) apresentaram um comportamento médio muito semelhante ao observado em plantas individuais durante o processo de seleção (Figura 3). Em ambos os casos a média da população esteve em torno de $10 \mathrm{~mm} \mathrm{dia}^{-1}$.

Embora a maioria das progênies tenham apresentado valores de CLR entre 9 a $11 \mathrm{~mm} \mathrm{dia}{ }^{-1}$, muitas progênies apresentaram valores de CLR extremos, evidenciando a existência de variabilidade genética, o que pode ser confirmado pela análise da variância (Tabela 26) que permitiu detectar diferenças estatisticamente significativas entre as progênies estudadas. 


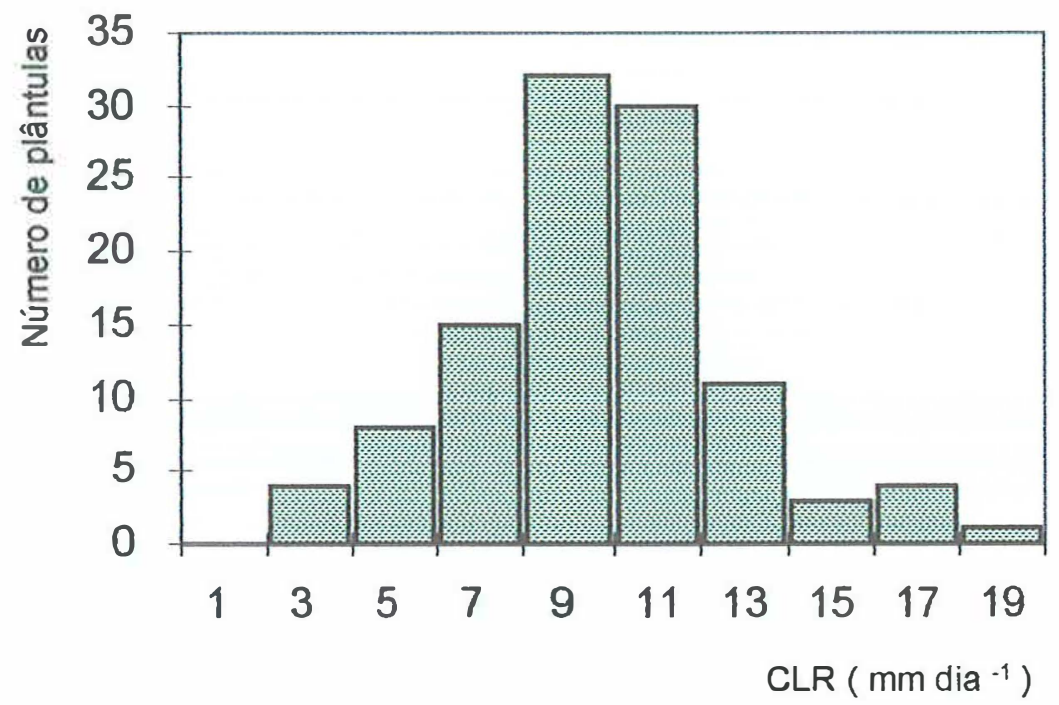

Figura 12 - Distribuição de frequências do caráter Crescimento líquido da raiz (CLR) em progênies de meios irmãos da população SIKALQ.

Tabela 26 - Tabela de ANAVA para plantas individuais para o caráter CLR.

\begin{tabular}{|c|c|c|c|c|}
\hline Fonte & GL & $\mathbf{Q M}$ & \multicolumn{2}{|c|}{ Estimativas } \\
\hline & & $0,0>0$ & & \\
\hline Progênies & 98 & $1,625 * *$ & $\hat{\sigma}_{p}^{2}=0,06$ & $\mathrm{~h}^{2}=0,74$ \\
\hline Erro & 490 & $0,258^{N S}$ & $\hat{\sigma}_{\mathrm{e}}^{2}=-0,002$ & $h_{m}^{2}=0,84$ \\
\hline Dentro & 1632 & 0,265 & $\hat{\sigma}_{d}^{2}=0,265$ & $\mathrm{G}_{\mathrm{s}}=3,11$ \\
\hline Total & 2225 & & & $\mathrm{ds}=4,154$ \\
\hline $\mathrm{CVe} \%$ & 23,95 & & & \\
\hline
\end{tabular}




\subsubsection{1 - Plantas individuais}

Os componentes da variância, para plantas individuais, foram estimados utilizando o método prático de Hicks. Como a quantidade de plântulas dentro de cada progênie não foi a mesma, o valor de $k$ foi substituido pela média harmônica $\left(\overline{\mathrm{K}}_{\mathrm{h}}\right)$ de $3 ; 82$.

O valor de herdabilidade estimado para plantas individuais $(0,74)$ está em concordância com o reportado por Lima et al. (1992), que estimaram para uma geração $\mathrm{F}_{2}$ um coeficiente de herdabilidade de 0,70 . Este resultado permite concluir que o caráter CLR, pelo menos na população em estudo, apresenta um coeficiente de herdabilidade considerado intermediário a alto, o que pode sugerir que se trata de um caráter quantitativo com marcante efeito aditivo. Outros autores reportaram uma conclusão semelhante (Sawasaki \& Furlani, 1987; Magnavaca et al., 1987; Lima et al., 1992; Pandey et al., 1994b; Duque Vargas et al., 1994; Borrero et al , 1995; Salazar et al., 1997).

\subsubsection{2 - Média de progênies}

O fato de que a herdabilidade estimada ao nível de progênies $(0,84)$ seja superior à de plantas individuais $(0,74)$, poderia estar sugerindo a presença de algum componente não aditivo, provavelmente de dominância, na expressão do caráter. A presença de ação gênica não aditiva, em especial dominância, foi reportada para tolerância a solos ácidos na cultura de milho por outros autores (Magnavaca et al., 1987; Duque Vargas et al., 1994). 


\section{5 - QUINTA ETAPA: Avaliação da utilização de marcadores bioquímicos .}

\subsection{1 - Isoenzimas: Experimentos preliminares}

Após inúmeras tentativas sem sucesso de encontrar um sistema isoenzimático que apresentasse resultados consistentes em todas as avaliações e que pudesse ser considerado como marcador para selecionar genótipos tolerantes ao alumínio seria possivel concluir que as isoenzimas não seriam marcadores indicados para este tipo de pesquisa. Sistemas enzimáticos como Catalase, Peroxidase e Fosfatasse Ácida apresentaram-se como os mais promissores porém fracassaram pela baixa consistência apresentada e a baixa correlação apresentada com indices confiáveis como o crescimento liquido da raiz principal.

O tratamento de indução com aluminio, embora não tenha permitido detectar a presença de bandas especificas, teve em alguns sistemas respostas interessantes. Por exemplo, os sistemas Xiquimato Desidrogenase, Peroxidase e Fosfoglucose Isomerase apresentaram bandas mais intensas nos genótipos tolerantes, enquanto nos sistemas Peroxidase e Enzima Málica, foram as sucetíveis as que apresentaram a maior intensidade. Embora estes resultados possam parecer promissores, é importante destacar a falta de consistência devido à baixa repetibilidadeobservada na medida em que se repetiam os experimentos.

Esta falta de resultados positivos observada quando se utilizam sistemas isoenzimáticos como marcadores para selecionar genótipos tolerantes ao alumínio, explica em parte a ausência total de literatura pertinente. 


\subsection{2 - Coloração com hematoxilina: Experimentos preliminares}

\subsubsection{1 - Experimento 1: Determinação do tempo de exposição ao alumínio.}

Os resultados obtidos no experimento 1 são apresentados na figura 13, onde foi possível visualizar que a nível de médias de tratamentos e repetições, não foram observadas diferenças importantes no comportamento das populações ao longo dos diferentes tempos de exposição ao alumínio .

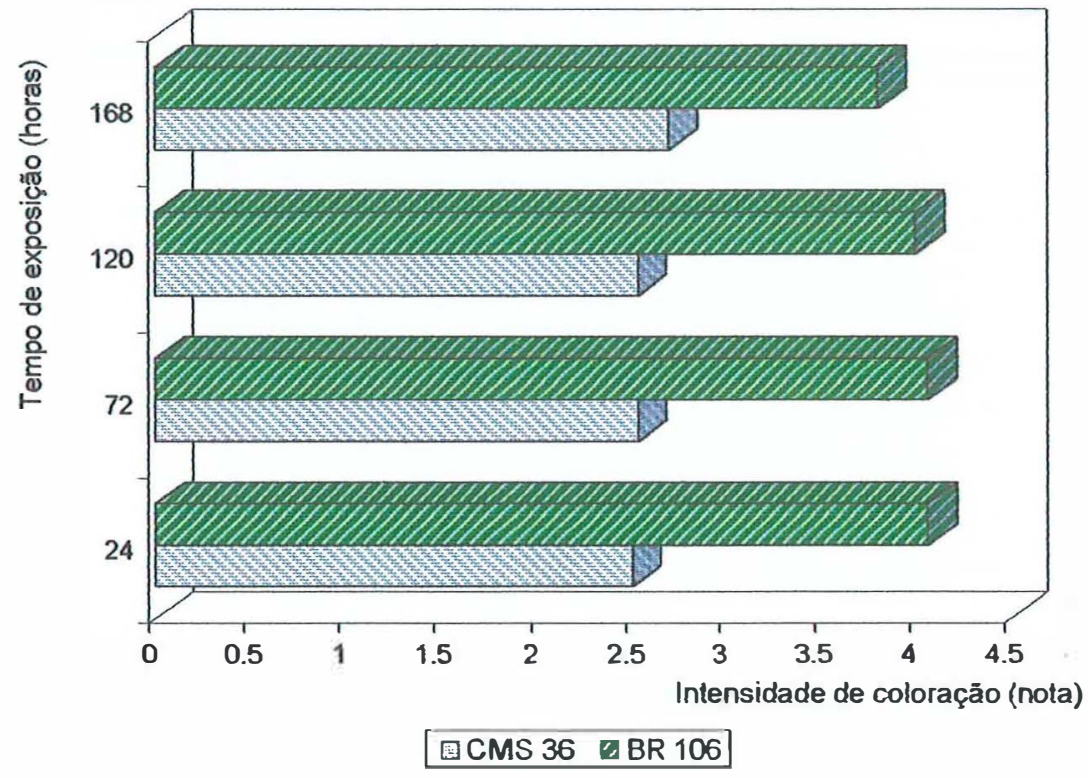

Figura 13 - Comportamento médio das populações nos diferentes tempos de exposição ao alumínio.

Essa situação pode ser comprovada ao analisar os resultados da análise da variância (Tabela 27), onde foi possível observar diferenças estatisticamente significativas entre as populações.Este resultado é razoável uma vez que os materiais são contrastantes, no que se refere à tolerância ao alumínio e que as diferenças entre tempos de exposição e entre as repetições não foram significativas. 
Tabela 27. Tabela de ANAVA do Experimento 1 de coloração com hematoxilina

\begin{tabular}{lcccc}
\hline Fonte & GL & SQ & QM & F \\
\hline População & 1 & 12,04 & 12,04 & $260,8^{* *}$ \\
Repetições & 2 & 0,01 & 0,005 & $0,1^{\text {Ns }}$ \\
Tempo & 3 & 0,01 & 0,003 & $0,06^{\text {Ns }}$ \\
Erro & 17 & 0,78 & 0,05 & \\
\hline
\end{tabular}

CVe \% 15.56

*: **, Diferenças significativas ao 5 e $1 \%$ e ns, diferenças não significativas. CVe: Coeficiente de Variação Experimental.

Nesta análise não foram incluídos os valores das observações realizadas às 0 e 12 horas de exposição ao alumínio. Isto porque no primeiro caso, tal como esperado, não ocorreu a reação de coloração devido à ausência do íon metálico. No segundo caso a. coloração ocorreu, porém com pouca intensidade, não permitindo diferenciar claramente os diferentes níveis de tolerância. Como não houveram diferenças importantes entre os diferentes tempos de exposição, os resultados permitem recomendar a realização de experimentos com 24 horas de exposição, o que possibilita uma importante economia no tempo requerido durante o processo de seleção. 


\subsubsection{2 - Experimento 2: Otimização dos tempos de lavagem e coloração.}

Da observação visual de cada uma das alternativas de lavagem e coloração foi possivel concluir que a melhor alternativa, pelo menos, para o material testado foi:

- Lavado com água desmineralizada por $\underline{30}$ minutos com agitação constante. - Coloração com solução ao $2 \%$ por $\underline{15}$ minutos com agitação constante. .

- Lavado com água desmineralizada por $\underline{20}$ minutos com agitação constante.

\subsubsection{3 - Experimento final: Comprovação da eficiência da técnica.}

Nos últimos anos, algumas metodologias têm sido propostas como alternativas aos experimentos de campo para avaliar a tolerância ao alumínio, principalmente com a finalidade de evitar a marcante variabilidade nos resultados devido a alterações no ambiente. Para isso tem sido propostas metodologias de avaliação no estado de plântula sob condições controladas que permitam obter informações mais precisas e selecionar as plantas antes do florescimento. Assim, metodologias de seleção de plântulas utilizando o crescimento radicular tanto em solução nutritiva como em vasos com solo com altos teores de alumínio têm sido muito utilizadas. Segundo Ma et al. (1997) estas metodologias baseadas no desenvolvimento radicular ao nivel de plantas individuais demandam bastante trabalho. Para facilitar as tarefas de seleção, técnicas de coloração como hematoxilina (Polle et al., 1978; Aniol, 1995; Crawford \& Wilkens, 1998) e eriocrome cianine (Ma et al., 1997) foram propostas. Em função do comportamento dos materiais neste experimento foi possivel estabelecer que a coloração com hematoxilina permitiu diferenciar claramente as populações. Uma situação semelhante aconteceu quando os materiais foram comparados utilizando o parâmetro CLR (Tabela 28). 
Tabela 28 - Valores médios de Crescimento líquido da raiz (CLR) e coloração com hematoxilina $(\mathrm{CH})$ e correlação fenotípica existente entre elas.

\begin{tabular}{|c|c|c|c|c|c|}
\hline \multirow{2}{*}{$\begin{array}{l}\text { Populações } \\
\text { SIKALQ }\end{array}$} & \multicolumn{2}{|c|}{$\begin{array}{c}\text { CLR ** } \\
\left(\mathrm{mm} \mathrm{dia}^{-1}\right)\end{array}$} & \multicolumn{2}{|c|}{$\begin{array}{l}\mathbf{C H} * * \\
(\text { nota })\end{array}$} & \multirow{2}{*}{$\frac{r_{\mathrm{F}}}{-0,77^{*}}$} \\
\hline & 12,99 & $\mathrm{~A}$ & 3,04 & $\mathrm{~B}$ & \\
\hline C-1 TSN & 14,55 & A & 2,55 & $\mathrm{~B}$ & $-0,79 * *$ \\
\hline C-1 SSN & 10,45 & B & 3,81 & A & $-0,75^{* *}$ \\
\hline Todas as plantas & & & & & $-0,82 * *$ \\
\hline CVe \% & \multicolumn{2}{|c|}{18.57} & \multicolumn{2}{|c|}{22.55} & \\
\hline
\end{tabular}

*: **. Diferenças significativas ao 5 e $1 \%$ e ns, diferenças não significativas Médias seguidas pela mesma letra não diferem estatisticamente para o teste de Duncan. CVe: Coeficiente de Variação Experimental.

O grau de associação entre as duas variáveis estudadas (Tabela 28) foi alto e negativo, isto porque as plântulas tolerantes apresentaram valores altos de CRL e, portanto, uma menor nota na coloração com hematoxilina (Figura 14).

Esses resultados estão em concordância com os reportados por Cançado (1997) onde a correlação entre CH e CLR foi de -0,693 e entre CH e CRR (Crescimento Relativo da Raiz) foi de $-0,816$.

Guevara et al (1992) estabeleceram a possibilidade da utilização da coloração com hematoxilina como técnica para avaliar tolerância ao alumínio em milho. Estes resultados foram parcialmente confirmados por Ryan et al. (1993).

Em função dos resultados obtidos foi possivel concluir que a coloração com hematoxilina é uma metodologia adequada para selecionar plântulas de milho por ser simples, rápida, permitindo avaliar muitos individuos e não danificando a plântula. 


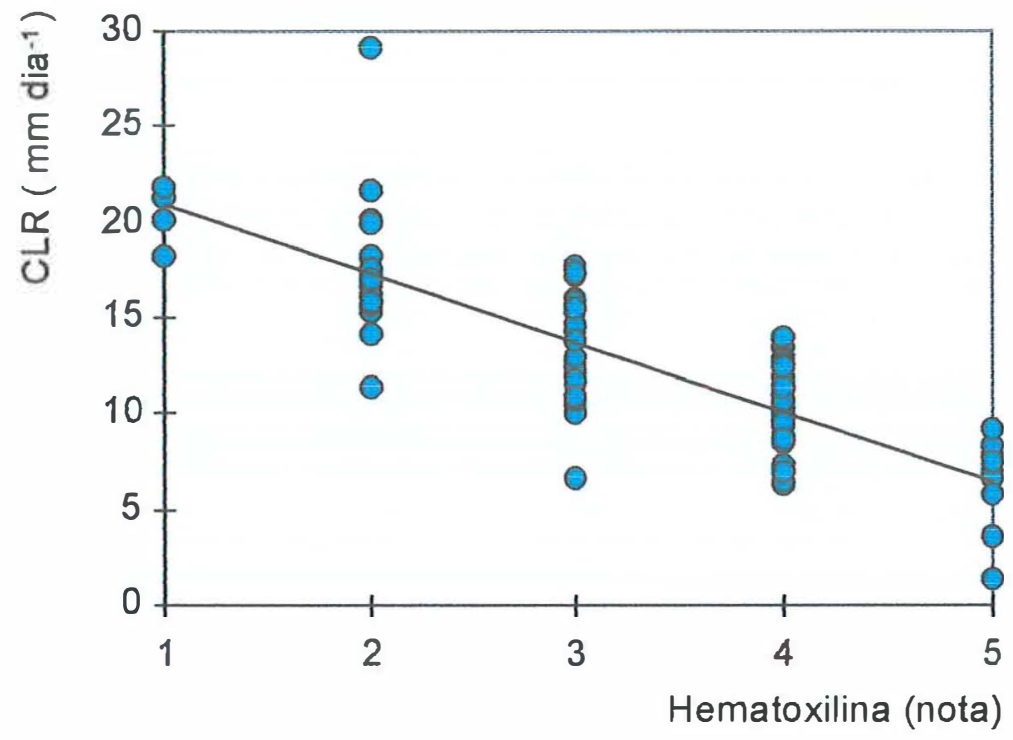

Figura 14 - Associação entre o Crescimento líquido da raiz (CLR) e a coloração com hematoxilina $(\mathrm{CH})$. 


\section{5 - CONSIDERACÕES FINAIS}

As duas metodologias de seleção de plântulas em casa de vegetação foram muito eficientes na detecção dos genótipos contrastantes, permitindo tanto a realização de um processo de seleção divergente eficiente como a caracterização posterior dos materiais. Foi possivel detectar essa eficiência porque as populações selecionadas apresentaram os melhores rendimentos sob condições de estresse e porque as variáveis utilizadas como critérios de seleção pelas duas metodologías, apresentaram correlações relativamente altas com a produção de grãos no campo (0,68 para AV e 0,52 para CLR).

Do ponto de vista prático a seleção em vasos com solo álico, embora os melhores resultados tenham sido obtidos no campo por representar melhor as condições de estresse, é um processo um pouco mais dificil de ser realizado por apresentar maior dificuldade no manejo das plantas e especialmente pela necessidade de realizar uma avaliação visual. Já as soluções nutritivas apresentam um manejo mais simples e uma melhor quantificação da tolerância.

Um fato importante a ser ressaltad o é que as populações tolerantes apresentaram os melhores comportamentos, quando avaliadas nas condições em que foram selecionadas. Assim C-1TSN foi sensivelmente superior a C-1 TSA no experimento em solução nutritiva e a situação inversa foi observada no experimento em vasos. Estes resultados poderiam estar sugerindo que as duas metodologias de seleção estariam detectando mecanismos de tolerância diferentes.

Uma boa parte do sucesso obtido nos processos de seleção foi devido, provavelmente, à introgressão de SIKUANI na população local que permitiu aumentar tanto a variabilidade genética para tolerância ao alumínio, como o potencial de rendimento das populações resultantes. Paralelamente a essas vantagens, o cruzamento da população local com um material de maior potencial produtivo, aumentou sensivelmente a porcentagem de acamamento, especialmente em safrinha. Com isto, ficou evidente a importância da realização de comparações e caracterizações de materiais em experimentos em vários locais com ambientes contrastantes. 


\section{5 - CONCLUSÕES}

Os resultados obtidos permitiram concluir que:

- As duas metodologias de seleção avaliadas foram eficientes, porque as populações selecionadas como tolerantes superaram à original e às selecionadas como suscetíveis.

- Em geral, tanto no campo como em casa de vegetação, a seleção em vasos com solo álico apresentou-se como a melhor alternativa de seleção de plântulas tolerantes ao alumínio.

- Foi encontrada uma boa associação entre os resultados em casa de vegetação e a produção de grãos. Os caracteres avaliação visual e crescimento líquido da raiz apresentaram as melhores correlações com a produção de grãos nos locais com alta saturação com alumínio.

- O crescimento líquido da raiz apresentou-se como um caráter quantitativo com efeitos predominantemente aditivos.

- Dentre os sistemas isoenzimáticos testados, não foi possivel estabelecer nenhum sistema associado à tolerância ao alumínio em milho.

- A coloração com hematoxilina se apresentou como uma técnica rápida, simples e muito eficiente na deteção de genótipos tolerantes e suscetiveis ao alumínio. 


\section{REFERÊNCIAS BIBLIOGRÁFICAS}

ALBRECHT, B.; DUDDLEY, J.W. Evaluation of four maize populations containing different proportions of exotic germoplasm. Crop Science, v. 27, p. 480-486, 1987.

ALFENAS, A.C.; PETERS, Y.; BRUNE, W. ; PASSADOR, G.C. Eletroforese de proteínas e isoenzimas de fungos e essências florestais. Viçosa:UFV, 1991. 242 p.

ANDRADE, F.H.; UHART, S.A.; CIRILO, A.G. Temperature affects radiation use efficiency in maize. Field Crops Research, v. 32, p. 17-25, 1993.

ANDRADE, F.H.; CIRILO, A.G.; UHART, S.A.; OTEGUI, M.E. Ecofisiología del cultivo de maíz. Balcarce: Dekalpress, 1996. 289p

ANIOL, A. M. Induction of aluminum tolerance in wheat seedlings by low doses of aluminum in nutrient solution. Plant Physiology, v.75, p. 551-555, 1984.

ANIOL, A.M. Physiological aspects of aluminum tolerance associated with the long arm of chromosome 2D of the wheat (Triticum aestivum L.) genome. Theoretical and Applied Genetics, v.9, p. 510-516, 1995.

BASU, A.; BASU, U.; TAYLOR, G.J. Induction of microsomal membrane proteins in roots of an aluminum-resistant cultivar of Triticum aestivum L. under conditions of aluminum stress. Plant Physiology, v. 104, p. 1007-1013, 1994. 
BIANCHI HALL, C.M.; CARTER, T.E.; RUFTY, T.W.; ARELLANO, C; BOERMA, H.R.; ASHLEY, D.A.; BURTON, J.W. Heritability and resource allocation of aluminum tolerance derived from soybean PI416937. Crop Science, v.38, p.513$522,1998$.

BLACK, C.A. Relaciones suelo-planta. Ames: Iowa Press, 1967. 444 p.

BORRERO, J.; PANDEY, S.; CEBALlOS, H.; MAGNAVACA, R.; BAHÍA FILHO, A.F.C. Genetics variances for tolerance to soil acidity in a tropical maize population. Maydica, v.40, p.283-288, 1995.

BRACCINI，M.C.L.; BRACCINI，A.L.; MARTINEZ，H.E.P.; PEREIRA，P.R.G.; FONTES, P.C.R. Técnicas de avaliação da toxidez do alumínio em plântulas de feijão ( Phaseolus vulgaris L.) cultivadas em solução nutritiva. Revista Ceres, v. 43, p.3-16, 1996.

BRIDGES, W.C.; GARDNER, C.O. Foundation populations for adapted by exotic crosses. Crop Science, v. 27, p. 501-506, 1987.

BRONDANI, C.; PAIVA, E. Análise de RFLP da tolerância a toxidez do aluminio no cromossomo 2 do milho. Pesquisa Agropecuária Brasileira, v. 31, p. 575-579, 1996.

CAMPBELL, T.A.; ELGIN, J.H. ; FOY, C.D.; MURTREY, J.E. Selection in alfalfa for tolerance to toxic levels of Aluminum. Canadian Journal of Plant Science, v. 68, p. $743-753,1988$. 
CANÇADO, G.M.A. Aspectos bioquímicos e genéticos da tolerância ao alumínio tóxico em milho. Viçosa, 1997. 92p. Dissertação ( Mestrado) - Universidade Federal de Viçosa.

CARVER, B.F.; INSKEEP, W.P.; WILSON, N.P.; WESTERMAN, R.L. Seedling tolerance to aluminum toxicity in hard winter wheat germplasm. Crop Science, v. 28, p. $463-466,1988$.

CIRILO, A.G.; ANDRADE, F.H. Sowing date and maize productivity: II. Kernel number determination. Crop Science, v.34, p. 1044 -1046, 1994.

CLARKSON, D.T. The effect of aluminum and some other trivalent metal cations on cell division in the root apices of Allium cepa. Annals of Botany, v.29, p. 309-315, 1965.

CRAWFORD, S.A.; WILKENS, S. Effect of aluminum on root elongation in two Australian perennial grasses. Australian Journal of Plant Physiology, v. 25, p. 165-171. 1998.

CROSSA, J.; GARDNER, C.O. Introgression of an exotic germplasm for improving an adapted maize population. Crop Science, v.27, p. 187-190, 1987.

DALL' AGNOL, M.; BOUTON, J.H.; PARROT, W.A. Screening methods to develop alfalfa germplasms tolerant of acid, aluminum toxic soils. Crop Science, v. 36, p. $64-70.1996$. 
DELHAIZE, E.; CRAIG, S.; BEATON, C; BENNET, R.J.; JAGANDISH, V.C.; RANDALL, P.J. Aluminum tolerance in wheat (Triticum aestivum L.). I. Uptake and distribution of aluminum in root apices. Plant Physiology, v. 103, p. 685-693, 1993.

DONALD, C.M.; HAMBLIN, J. The biological yield and harvest index of cereals as agronomic and plant breeding criteria. Advances in Agronomy, v.28, p.361-405, 1976.

DUNCAN, W.G.; SHAVER, D.L.; WILLIAMS, W.A. Insolation and temperature effects on maize growth and yield. Crop Science, v. 13, p. 187-191, 1973.

DUQUE VARGAS, J.; PANDEY, S.; GRANADOS, G.; CEBALLOS, H.; KNAPP, E. Inheritance of tolerance to soil acidity in tropical maize. Crop Science, v.34, p.50$54,1994$.

EDMEADES, D.C.; BLAMEY, F.P.C.; ASHER, C.J.; EDWARDS, D.G. Effects of pH and aluminum on the growth of temperate pasture species. I. Temperate grasses and legumes supplied with inorganic nitrogen. Australian Journal of Agricultural Research, v. 42, p.559-569, 1991.

FARALDO, M.I.F. Distribuição da variabilidade genética e caracterização isoenzimática de etnovariedades em roças de mandioca (Manihot sculenta Krantz) do Brasil. Piracicaba, 1999. 117 p. Tese Doutorado Escola Superior de Agricultura "Luiz de Queiroz", Universidade de São Paulo. 
FERREIRA, M.E; GRATAPAGLIA, D. Introdução ao uso de marcadores RAPD e RFLP em anáiise genética. Brasilia : EMBRAPA, 1995. 220 p.

FONSECA Jr., N.S. Estudo da herança da tolerância ao alumínio em soja (Glycine max L. Merrill) pelo método da hematoxilina.Viçosa, 1982. 46p. Dissertação (Mestrado)- Universidade federal de Viçosa.

FONSECA Jr., N.S.; SEDIYAMA, M.; PEREIRA, M.G.; YAMADA, M.M.; TRAGNAGO, J.L. Método de deteção visual da sensibilidade ao alumínio em soja (Glycine $\max$ L. Merrill). In: SEMINÁRIO NACIONAL DE PESQUISA DE SOJA, 2., Londrina, 1981. Anais. Londrina: EMBRAPA, 1982. p. 678-685.

FURLANI, P.R. Tolerância de cultivares de milho ao alumínio. In: SEMINÁRIO SOBRE A CUltURA DO MILHO "SAFRINHA", 4., Assis, 1996. Anais. Assis: IAC, 1997. p.171-174.

FURLANI, A.M.C.; FURLANI, P.R. Composição e pH de soluções nutritivas para estudos fisiológicos e seleção de plantas em condições nutricionais adversas. Campinas : IAC, 1988. 34 p. (IAC Boletim técnico, 121).

FURLANI, P.R.; LIMA, M.; MIRANDA, L.T.; MIRANDA, L.C.E.; SAWAZAKI, E.; MAGNAVACA, R. Avaliação de linhagens, materiais comerciais e duas populações de milho para tolerância ao alumínio. Pesquisa Agropecuária Brasileira, v.21, n.6, p.655-660,1986.

GARCIA, O.; SILVA, W.J.; MASSEI, M.A.S. An efficient method for screening maize inbreds for aluminum tolerance. Maydica, v. 24, n. 2, p.75-82, 1979. 
GASSMANN, W.; SCHROEDER, J.I. Inward rectifying $\mathrm{K}^{+}$channels in root hairs of wheat. A mechanism for aluminum-sensitive low affinity $\mathrm{K}^{-}$uptake. Plant Physiology, v. 105, p. 1399-1408, 1994.

GRANADOS, G.; PANDEY, S.; CEBALLOS, H.; Registration of acid soil tolerant maize population SA-3 and SA-8. Crop Science, v. 35, p. 1236, 1995.

GRANADOS, G.; PANDEY, S.; CEBALLOS, H; DUQUE -VARGAS, J.; LEON, L.A; VARGAS, J.E.; TORRES, G.; NAVAS, A.; AVILA, L.G. ; CESPEDES, P.L.M. Sikuani V110, the first maize variety in Colombia with tolerance of acid soils. In: REUNION LATINOAMERICANA, 3.; REUNION DE LA ZONA ANDINA DE INVESTIGADORES EN MAIZ, 16, Cochabamba, 1995, CIMMYT. Memorias. p. $195-217$.

GUEVARA, P.; POSCHENRIEDER, C.; BARCELÓ; J. Differential response of four maize (Zea mays L.) varieties to aluminum toxicity. Suelo y Planta, v. 2, p. 713$721,1992$.

HALLAUER, A.R. Potential of exotic germoplasm for maize improvement. In: WALDEN, D.B. (Ed.) Maize breeding and genetics. New York: John Willey, 1978. p. $229-247$.

HALLAUER, A.R.; MIRANDA FILHO, J.B. Quantitative genetics in maize breeding: 2.ed. Ames: Iowa State Press, 1988. 468p. 
HAYES, M. H . B. Influence of the acid/base status on the formation and interactions of acid and basis in soils. In ULRICH, B.; SŬMiMER M. (Ed.) Soil acidity. Germany. 1991. 224p.

HICKS, C.R. Fundamental concepts in the design of experiments. 2.ed. New York: Holt, Rinehart and Winston, 1973. 349 p.

HUANG, J.W.; SHAFF, J.E.; GRUNES, D.L.; KOCHIAN, L.V. Aluminum effects on calcium fluxes at the root apex of aluminum-tolerant and aluminum-sensitive wheat cultivars. Plant Physiology, v. 98, p. 230-237, 1992.

JACOBS, B.C.; PEARSON, C.J. Potential yield of maize determined by rates of growth and development of ears. Field Crops Research, v.27, p.281-289, 1991.

KOCHIAN, L.V. Cellular mechanisms of aluminum toxicity and resistance in plants. Annual Review of Plant Physiology and Plant Molecular Biology, v. 46, p. $237-260,1995$.

LIMA, M.; FURLANI, P.R.; MIRANDA FILHO, J.B. Divergent selection for aluminum tolerance in a maize (Zea mays L.) population. Maydica, v.37, p. 123-132, 1992.

LINDBERG, S. Aluminum interactions with $\mathrm{K}^{+}\left({ }^{86} \mathrm{Rb}^{-}\right)$and $\mathrm{Ca}^{2+}$ fluxes in three cultivars of sugar beet (Beta vulgaris). Physiologia Plantarum, v. 79, p.275-282, 1990.

LONNQUIST, J.H. Considerations and experiences with recombinations of exotic and com belt maize germplasms. In: ANNUAL CORN AND SORGHUM RESEACH CONFERENCE, 29, Chicago. Proceedings, ASTA, 1974. p. 102-117. 
LOPES, A.S.; COX, F.R. A survey of the fertility status of surface soils under "cerrado" vegetation in Brazil. Soil Science Society of Ámerica Journal, v.4l, p.742-745, 1987.

MA, J. F.; ZHENG, S. J.; LI, X.F.; TAKEDA, K.; MATSUMOTO, H. A rapid hydroponic screening for aluminum tolerance in barley. Plant and Soil, v.191, p.133-137, 1997.

MAGNAVACA, R. Genetic variability and the inheritance of aluminum tolerance in maize (Zea mays L.). Lincoln, 1982. 135p. Thesis (Ph.D.) - University of Nebraska.

MAGNAVACA, R.; GARDNER, C.O.; CLARK, R.B. Inheritance to aluminum tolerance in maize. In : GALBEMAN, W.H.; LOUGHMAN, B.C. (Ed.) Genetics aspects of plant mineral nutrition. The Hage : Martinus Nijhoff, 1987. p.201-212.

MAKAY, A.D.; CARRADUS, J.R.; WEWELA, S. Aluminum toxicity of forage species. In : WRIGHT, R.J; BALIGAR, V.C.; MURRMANN, R.P. (Ed.) Plant-soil interactions at low pH. Dordrecht : Kluwer Academic, 1991. p. 925-930.

MALAVOLTA, E. ; SARRUGE, J.R.; VITTENCOURT, V.C. Toxidez de alumínio e manganês. In : SIMPOSIO SOBRE O CERRADO, Brasília : Editora Itatiaia, 1977. p.275-301.

MIRANDA, L.T.; FURLANI, P.R.; MIRANDA, L.E.C.; SAWAZAKI, E. Genetics of environmental resistance and super genes: latent, aluminum tolerance. Maize Cooperation Newsletter, v. 58, p.46-48, 1984. 
MIRANDA FILHO, J.B. Breeding methodologies for tropical maize. In: BRANDOLINI, A.; SALAMINI, F. (Ed.) Breeding strategies for maize production improvement in the tropics. Firenze: FAO, 1985. p. 177-206.

MIRANDA FILHO, J.B. Exotic germplasm introduced in a Brazilian maize breeding program. Revista Brasileira de Genética, v. 15, p. 631-642, 1992.

MORO, J.R.; NASPOLINI FILHO, V.; VIANNA, R.T.; GAMMA, E.E.G. Introdução de novos germoplasmas de milho no Brasil. Pesquisa Agropecuária Brasileira, v. 16, p. $867-882,1981$.

MIYASAKA, S.C.; BUTA, J.G; HOWELL, R.K.; FOY, C.D. Mechanism of aluminum tolerance in snapbeans. Root exudation of citric acid. Plant Physiology, v.96, p. 737-743, 1991 .

MIYASAKA, S.C.; KOCHIAN, L.V.; SHAFF, J.E.; FOY, C.D. Mechanisms of aluminum tolerance in wheat. An investigation of genotypic differences in rhizosphere $\mathrm{pH}, \mathrm{k}^{+}$, and $\mathrm{H}^{+}$transport, and root-cell membrane potentials. Plant Physiology, v.91, p. 1188-1196, 1989 :

MURCHOW, R.C. Effects of nitrogen supply on the comparative productivity of maize and sorghum in semi-arid tropical environment. I. Leaf growth and leaf nitrogen. Field Crops Research, v.18, p.1-16, 1988.

NASS, L.L. Variabilidade genética de populações semi-exóticas de milho (Zea mays L.). Piracicaba, 1992. 136p. Tese (Doutorado) Escola Superior de Agricultura "Luiz de Queiroz", Universidade de São Paulo. 
NOVOA, R.; LOOMIS, R.S. Nitrogen and plant production. Plant and Soil, v.58, p. $177-204,1981$.

PANDEY, S.; CEBALlOS, H.; GRANADOS, G. ; KNAPP, E. Developing maize that tolerants aluminum toxic soils. In: EDMEADES, G.E.; DEUTSCH, J.A. (Ed.) Stress tolerance breeding: maize that resist insects, drought, low nitrogen and acids soils. Mexico : CIMMYT, 1994 a. p. 85-92.

PANDEY, S. ; CEBALlOS, H.; MAGNAVACA, R.; BAHÍA - FILHO, A.F.C.; DUQUE-VARGAS, J.; VINASCO, L.E. Genetics of tolerance to soil acidity in tropical maize. Crop Science, v. 35, p. 1511-1514, 1994 b.

PATERNIANI, E. Selection among and within half-sib families in a Brazilian population of maize (Zea mays L.). Crop Science, v.7, p. 212-215, 1967.

PATERniani, E. Maize breeding in the tropics. Critical Reviews in Plant Science, v.9, p. $125-54,1990$.

PINTRO, J.; BARLOY, J.; FALLANER, P. Aluminum toxicity in corn plants cultivated in a low ionic strength nutrient solution 1. Discrimination of two cultivars. Revista Brasileira de Fisiologia Vegetal, v. 7, p. 121-128, 1995a.

PINTRO, J.; BARLOY, J.; FALLANER, P. Aluminum toxicity in corn plants cultivated in a low ionic strength nutrient solution 2. Distribution of $\mathrm{Al}$ in the principal root tip zone. Revista Brasileira de Fisiología Vegetal, v. 7, p. 129-134, $1995 \mathrm{~b}$. 
POLLE, E.; KONSAK, C. F.; KITTRICK, J.A. Visual detection of aluminum tolerance in wheat by hematoxylin staining of seedling roots. Crop Science, v. 18, p.823-827, 1978.

PRIOLI, A.J. Análise genética da tolerância à toxidez do alumínio em milho (Zea mays L.). Campinas, 1987.182 p. Tese Doutorado, Universidade de Campinas.

PRIOLI, S.M.A.P.; SILVA, J.C.; GALVÃO, J.D.; NONNERAT, P.H.; PRIOLI, A.G. Seleção para tolerância a toxidez de alumínio em milho (Zea moys L.). Revista Ceres, v.3, n.183, p. 441-451, 1985.

REGITANO NETO, A.; NASS, L.L.; MIRANDA FILHO, J.B. Potencial de germoplasma exótico de milho no melhoramento do ciclo e da arquitetura da planta. In: CONGRESSO NACIONAL DE MLLO E SORGO, Londrina, 1996. Anais. Londrina: IAPAR, 1997. p. 104.

RENGEL, Z; ELLIOT, D.C. Mechanism of aluminum inhibition of net ${ }^{45} \mathrm{Ca}^{+2}$ uptake by Amaranthus protoplast. Plant Physiology, v.98, p.632-638, 1992.

RHUE, R.D.; GROGAN,C.O; STOCKMEYER, E.W.; EVERETT, H.L. Genetic control of aluminum tolerance in corn. Crop Science, v. 18, p. 1063-1067, 1978.

RICHARDS, K.D.; SNOWDEN, K.C.; GARDNER, R.C. wali6 and wali7. Genes induced by aluminum in wheat (Triticum aestivum L.) roots. Plant Physiology, v. 105, p. 1455-1456, 1994. 
RINCÓN, M.; GONZALES, R.A. Aluminum partitioning in intact roots of aluminumtolerant and aluminum-sensitive wheat (Triticum aestivum L.) cultivars. Plant Physiology, v.99, p. 1021-1028, 1992.

RYAN, P.R.; DITOMASO, J.M.; KOCHIAN, L.V. Aluminum toxicity in roots: an investigation of spatial sensitivity and the role of the root cap. Journal of Experimental Botany, v.44, p. 437-446, 1993.

SALAZAR, F.; PANDEY, S.; NARRO, L.; PEREZ, J.C.; CEBALLOS, H.; PARENTONI, S.; BAHÍA FILHO, A.F.C. Diallel analysis of acid soil tolerant and intolerant tropical maize populations. Crop Science, v. 37, p. 1457-1462, 1997.

SANTOS, M.X. Estudo do potencial genético de duas raças brasileiras de milho (Zea mays L.) para fins de melhoramento. Piracicaba, 1985. 186p. Tese (Doutorado) Escola Superior de Agricultura "Luiz de Queiroz", Universidade de São Paulo.

SAS INSTITUTE. SAS / STAT procedure guide for personal computers. version 5. Cary, 1991. $494 \mathrm{p}$.

SAWAZAKI, E.; FURLANI, P.R. Tolerância ao aluminio em linhagens de milho cateto. Bragantia, v.46, p. 269-278, 1987.

SILVA, R.M. Sistema reprodutivo, fluxo gênico e paternidade em roça de etnovariedades de mandioca (Manihot sculenta Crantz). Piracicaba, 2000. 131 p. Tese (Doutorado) - Escola Superior de Agricultura "Luiz de Queiroz", Universidade de São Paulo.

SPEHAR, C.R.; MAKITA, M. Tolerância ao aluminio em plântulas de soja e sua utilização. Pesquisa Agropecuária Brasileira, v. 29, p. 1927-1932, 1994. 
TANSKELEY, S.D.; MEDINA FILHO, H.; RICK, C. M. Use of naturally occurring enzyme variation to detect and map genes controlling. Quantitative traits in an interespecific backcross in tomato. Heredity, v. 49, p.11-25, 1982.

TAYLOR, G.J. The physiology of aluminum tolerance in higher plants. Soil Science and Plant Analysis, v. 19, n.7-12, p.1179-1194, 1988.

TICE, K.R.; PARKER, D.R.; DEMASON, D.A. Operationally defined apoplastic and symplastic aluminum fractions in root tips of aluminum-intoxicated wheat. Plant Physiology, v.100, p. 309-318, 1992.

TOLLENAAR, M.; DWYER, L.M.; STEWART, D.W. Ear and kernel formation in maize hybrids representing three decades of grain yield improvement in Ontario. Crop Science, v.32, p.432-438, 1992.

TORRES, G.A.; PARENTONI, S.N.; LOPES, M.A.; PAIVA, E. A search for RFLP markers to identify genes for aluminum tolerance in maize. Brazilian Journal of Genetics, v. 20, p. 459-465, 1997.

UEXKÜLL, H.R.; MURTET, C.M. Global extent development and economic impact of acid soils. Plant and Soil, v.171, p. 1-15, 1995.

UHART, S.A.; ANDRADE, F.H. Source sink relationships in maize grown in a cool temperature area. Agronomie, v.11, p. 863-875, 1991.

UHART, S.A.; ANDRADE, F.H. Nitrogen deficiency in maize: I. Effects on crop growth, development, dry matter partitioning and kernel set. Crop Science, v.35, p. 1376-1383, 1995. 
URREA GÓMEZ, R.; CEBALlOS, H.; PANDEY, S.; BAHÍA FILHO, A.F.C.; LEÓN, L.A. A greenhouse screening technique for acid soil tolerance in maize. Ágronomy Journal, v. 88, p.806-812, 1996.

WAGATSUMA, T. ; ISHIKAWA, S.; OBATA, H.; TAWARAYA, K. ; KATODHA, S. Plasma membrane of younger and other cells is the primary specific site for aluminum toxicity in roots. Plant and Soil, v. 171, p. 105-112, 1995.

WALLACE, S.U.; ANDERSON, I.C. Aluminum toxicity and DNA synthesis in wheat roots. Agronomy Journal, v.76, p. 5-8, 1984.

WISSEMEIER, A.H.; DIENNING, A.; HERGENRODER, A. Callose formation as parameter for accessing genotypical plant tolerance of aluminum and manganese. Plant and Soil, v. 146, p.67-75, 1992.

ZHANG, G.; HODDINOT, J.; TAYLOR, G.J. Characterization of 1,3- $\beta$-D-glucan (callose) synthesis in roots of triticum aestivum in response to aluminum. Journal of Plant Physiology, v. 144, p.229-234, 1994.

ZHANG, X.G.; JESSOP, R.S.; ZHANG, G. Analysis of genetic variability of aluminum tolerance response in triticale. Euphytica, v. 102, p. 177-182, 1998. 